UNIVERSIDADE DE SÃO PAULO

ESCOLA DE ENGENHARIA DE LORENA

\title{
DANIEL COLLUCCI
}

Teor de sacarose, acúmulo de lignocelulose, dimensionamento celular e digestibilidade in vitro de entrenós de cana-de-açúcar em relação ao estágio de maturação e a genótipos de Saccharum spp. 



\section{DANIEL COLLUCCI}

Teor de sacarose, acúmulo de lignocelulose, dimensionamento celular e digestibilidade in vitro de entrenós de cana-de-açúcar em relação ao estágio de maturação e a genótipos de Saccharum spp.

Tese apresentada à Escola de Engenheria de Lorena da Universidade de São Paulo para obtenção do título de Doutor em Ciências do Programa de Pós-graduação em Biotecnologia Industrial na Área de Concentração de Conversão de Biomassa

Orientador: Prof. Dr. André Luis Ferraz

\section{Versão Corrigida}


AUTORIZO A REPRODUÇÃO E DIVULGAÇÃO TOTAL OU PARCIAL DESTE TRABALHO, POR QUALQUER MEIO CONVENCIONAL OU ELETRÔNICO, PARA FINS DE ESTUDO E PESQUISA, DESDE QUE CITADA A FONTE

Ficha catalográfica elaborada pelo Sistema Automatizado da Escola de Engenharia de Lorena, com os dados fornecidos pelo(a) autor(a)

Collucci, Daniel

Teor de sacarose, acúmulo de lignocelulose, dimensionamento celular e digestibilidade in vitro de entrenós de cana-de-açúcar em relação ao estágio de maturação e a genótipos de Saccharum spp. / Daniel Collucci; orientador André Ferraz - Versão Corrigida. - Lorena, 2019.

$77 \mathrm{p}$.

Tese (Doutorado em Ciências - Programa de Pós Graduação em Biotecnologia Industrial na Área de Conversão de Biomassa) - Escola de Engenharia de Lorena da Universidade de São Paulo. 2019

1. Recalcitrância da cana-de-açúcar. 2 . Digestibilidade enzimática. 3. Lignina. 4. Glucanas. 5. Xilanas. I. Título. II. Ferraz, André, orient. 


\section{AGRADECIMENTOS}

Ao Professor André Ferraz, devido ao apoio acadêmico e profissional, por criar um ambiente de trabalho motivador e amigável, devido a solicitude, e aos conhecimentos transmitidos.

Ao Professor Fernando Segato por criar oportunidades de trabalho que engrandeceram a experiência acadêmica e também devido a solicitude constante.

Ao Professor Valdeir Arantes devido a solicitude e a orientação durante o Programa de Aperfeiçoamento de Ensino (PAE).

A Professora Adriane Milagres devido a solicitude e a colaboração na pesquisa de doutorado. Ao “Zé” Moreira pela ajuda e orientação incondicional durante a condução dos experimentos. À CAPES pelo apoio financeiro.

Aos membros da banca examinadora, professores: Adriane Milagres, Igor Cesarino e Michel Brienzo por aceitarem o convite, e também devido as críticas construtivas e sugestões no presente trabalho.

E por fim aos colegas, em especial a Otto Heinz e Ana Maria, que de alguma forma colaboraram na realização deste trabalho. 



\section{RESUMO}

COLLUCCI, D. Teor de sacarose, acúmulo de lignocelulose, dimensionamento celular e digestibilidade in vitro de entrenós de cana-de-açúcar em relação ao estágio de maturação e a genótipos de Saccharum spp. 2019. 77p. Tese (Doutorado em Ciências) Escola de Engenharia de Lorena, Universidade de São Paulo, Lorena - SP, 2019.

Os híbridos de cana-de-açúcar adquiriram várias características através do melhoramento de plantas, incluindo a produção de sacarose e lignocelulose. Recentemente, indústrias baseadas em biomassa projetadas para produzir produtos químicos de alto valor agregado e biocombustíveis a partir da biomassa encorajaram novos esforços de melhoramento para desenvolver plantas com alto rendimento de sacarose e baixa recalcitrância de lignocelulose. O presente estudo utilizou 4 híbridos experimentais de canade-açúcar para avaliar a dinâmica de acúmulo de sacarose e lignocelulose, a composição química de lignocelulose e a digestibilidade enzimática durante a maturação dos entrenós. Durante os estágios de maturação dos entrenós, o teor de sacarose aumentou, enquanto a fração lignocelulósica apresentou um aumento na lignina e uma redução no conteúdo de glucanas. A digestibilidade enzimática e o teor de lignina da fração lignocelulósica apresentaram um padrão inversamente relacionado, sendo que o primeiro entrenó foi duas vezes mais digerível em comparação aos entrenós maduros, indicando que a digestibilidade diminui significativamente com a maturação dos entrenós e a lignificação dos tecidos. Os híbridos H89 e H58 combinaram características fenotípicas desejáveis (alto rendimento de sacarose e baixa recalcitrância de lignocelulose) a exploração combinada de açúcar, produtos químicos de alto valor agregado e biocombustíveis, que não foram detectados em H140 e H321. O conjunto de dados gerado foi analisado por análise de componentes principais (PCA). A análise de PCA permitiu corroborar quantitativamente a discriminação de amostras e mostrar que os autovetores do teor de lignina e de digestibilidade apresentaram sentidos inversos, bem como os autovetores do teor de glucana e de digestibilidade apresentaram o mesmo sentido. A avalaliação global dos dados permitiu inferir que marcadores moleculares específicos discriminando as características químicas e de digestibilidade da cana de açúcar podem contribuir para o desenvolvimento de novos híbridos que combinem elevados rendimentos de sacarose e baixa recalcitrância de lignocelulose.

Palavras-chave: Recalcitrância da cana-de-açúcar. Digestibilidade enzimática. Lignina. Glucanas. Xilanas. 


\begin{abstract}
COLLUCCI, D. Sucrose content, lignocelulose accumulation, cell wall anatomy characterization and in vitro digestibility of sugarcane internodes depicted in relation to maturation stage and Saccharum genotypes. 2019. 77p. Thesis (Doctoral of Science) Escola de Engenharia de Lorena, Universidade de São Paulo, Lorena - SP, 2019.

Sugarcane hybrids acquired several characteristics through plant breeding, including high sucrose and lignocellulose production. Recently, biomass-based industries designed to produce high-value chemicals and biofuels from whole plant biomass encouraged new breeding efforts to develop plants with high sucrose yield and low lignocellulose recalcitrance. The present study utilized four experimental sugarcane hybrids to evaluate the dynamics of sucrose and lignocellulose accumulation, lignocellulose composition, and enzymatic digestibility during internode development. During the internode maturation stages, the sucrose content increased while the lignocellulose fraction displayed an increase in lignin and a reduction in glucans contents. Enzymatic digestibility and lignin content of the lignocellulose fraction displayed an inversely related pattern, and the first internode was twice more digestible compared with mature internodes, indicating that digestibility decreases significantly with internode maturation and tissue lignification. Hybrids H89 and H58 combined desirable phenotype characteristics (high sucrose yield and low lignocellulose recalcitrance) essential for the combined exploitation of sugar, high-value chemicals and biofuels, that were not detected in H140 and H321. All sugarcane properties were evaluated by principal component analysis (PCA). PCA of the current data corroborate with previous observations in a quantitative maner showing that eigenvectors of lignin content and digestibility displayed an inverse direction whereas eigenvectors of glucan content and digestibility had the same direction. The overal data evaluation may help with the development of proper molecular markers that could discriminate sugar cane hybrids with desired characteristics, which could help to further design breeding steps to produce sugarcane modern hybrids combining high sucrose yields and low lignocellulose recalcitrance.
\end{abstract}

Keywords: Sugarcane. Cell Wall Recalcitrance. Biomass Enzymatic Digestibility. Lignin. Glucans. Xylans. 


\section{LISTA DE FIGURAS}

\section{Capítulo 1}

Figura 1.1 Arranjo estrutural dos fitômeros em um caule de cana-de-açúcar. A) Representação esquemática de um fitômero, B) Representação esquemática de um perfilho de cana-de-açúcar composto por uma série de fitômeros em estágios de desenvolvimento sucessivos

Figura 1.2 Representação esquemática da fotossíntese e da estrutura foliar de gramíneas C3 e C4 ... 17

Figura 1.3 Fluxograma da síntese de sacarose na cana-de-açúcar

Figura 1.4 Diagrama da síntese de celulose

Figura 1.5 Diagrama da síntese de hemiceluloses

Figura 1.6 Via de biossíntese de monolignóis em plantas vasculares. a) Enzimas envolvidas na síntese de lignina. b) Marcação da lignina no caule de Panicum spp por floroglucinol. c) Visualização da deposição de lignina por microscopia de fluorescência induzida por UV em um corte do caule de Medicago truncatula

Figura 1.7 Estrutura química da celulose 23

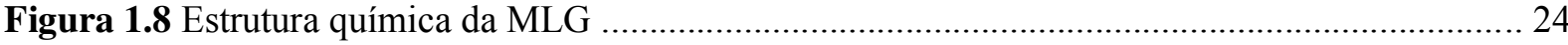

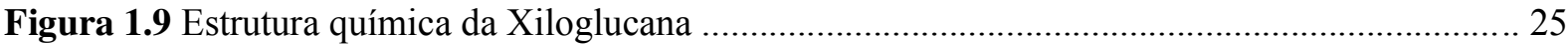

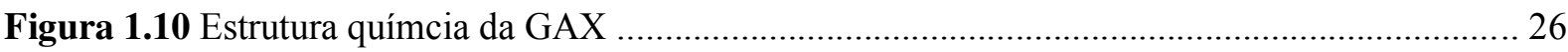

Figura 1.11 Estrutura complexa da lignina em diversos grupos vegetais. a) Giminosperma. b) Angiospermas e c) Monocotiledoneas

\section{Capítulo 2}

Figura 2.1 Identificação do primeiro nó completamente definido após a remoção das folhas do ápice do caule. O primeiro entrenó correspondeu a região em que os nós superiores e inferiores foram claramente identificados

Figura 2.2 Imagem microscópica típica da região do córtex do entrenó da cana ilustrando as áreas de uma célula do parênquima e do aglomerado vascular

Figura 2.3 Teores de sacarose (círculos azuis) e biomassa lignocelulósica (triângulos vermelhos) em relação à posição do entrenó no caule da cana. Os teores representam médias agrupadas dos híbridos H89, H58, H321 e H140 para cada entrenó

Figura 2.4 Dimensões celulares e teciduais da região do córtex de 3 entrenós em estágios diferentes de maturação de 4 híbridos de cana-de-açúcar. Amostras com as mesmas letras não diferem entre si pelo teste de Tukey com um nível de significância $P<0,1$

Figura 2.5 Composição química da biomassa lignocelulósica de 4 entrenós em estágios diferentes de maturação de 4 híbridos de cana-de-açúcar. Amostras com as mesmas letras não diferem entre si pelo teste de Tukey com um nível de significância $P<0,1$ 
Figura 2.6 Conversão de glucanas (A) e xilanas (B) após hidrólise enzimática in vitro de 4 entrenós em estágios diferentes de maturação de 4 híbridos de cana-de-açúcar. Amostras com as mesmas letras não diferem entre si pelo teste de Tukey com um nível de significância $P<0,1$

Figura 2.7 Modelos de regressões lineares simples e coeficientes de correlação que explicam os níveis de conversão de glucanas em função do conteúdo de glucanas dividido pela soma de ligninas e xilanas(A). Dados obtidos no trabalho atual (círculos azuis) sobrepostos com dados de COSTA et al. (2016) (triângulos vermelhos) (B)

Figura S1 Teores de sacarose e biomassa lignocelulósica de 4 genótipos de cana-de-açúcar em relação à estágios progressivos de maturação do entrenó

Figura S2 Composição química da biomassa lignocelulósica em função de estágios de maturação do entrenó de 4 híbridos de cana-de-açúcar

Figura S3 Cinéticas da conversão de glucanas e xilanas durante a digestibilidade enzimática in vitro de entrenós em estágios sucessivos de maturação de 4 genótipos de cana-de-açúcar

\section{Capítulo 3}

Figura 3.1 Análise de correlação entre as variáveis do conjunto de dados

Figura 3.2 Análise multivariada dos dados. a) variância dos dados atribuída a cada componente principal. b) variância cumulativa em função dos componentes principais

Figura 3.3 Representação dos híbridos-entrenóes (símbolos) de cada amostra calculados para os componentes principais 1 e 2 e dos autovetores (setas) calculados pela PCA 


\section{LISTA DE TABELAS}

\section{Capítulo 2}

Tabela S1 Características fenotípicas de 4 genótipos de cana-de-açúcar colhidos após 12 meses de rebrota (cana soca). Médias e desvios padrão foram calculados de 3 repetições experimentais

\section{Capítulo 3}

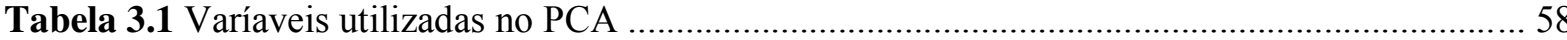

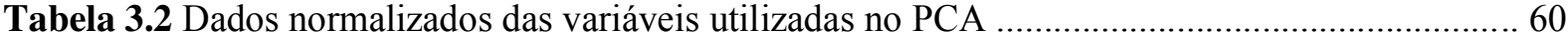





\section{SUMÁRIO}

\section{Capítulo 1}

1 INTRODUÇÃ

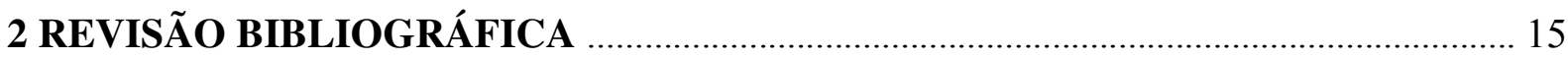

2.1 Morfologia e Anatomia da Cana-de-Açúcar ........................................................................... 15

2.2 Fotossíntese, Acúmulo de Sacarose e Lignocelulose ............................................................ 16

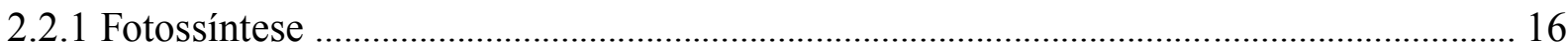

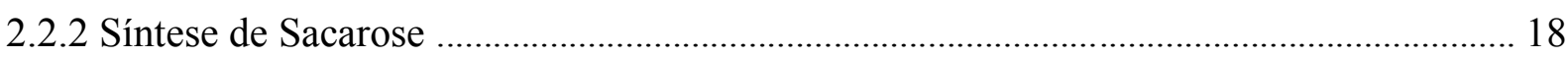

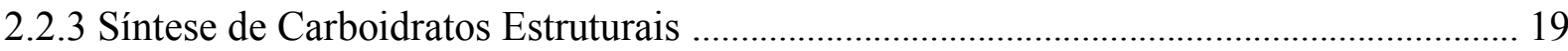

2.2.4 Síntese de Lignina e Ácidos Hidroxicinâmicos ......................................................... 21

2.3 Matriz Química, Desconstrução e Recalcitrância da Biomassa ........................................ 22

2.3.1 Matriz Química da Parede Celular ............................................................................. 22

2.3.2 Recalcitrância da Biomassa Lignocelulósica e Pré-tratamento Químico ...................... 27

2.3.3 Recalcitrância da Biomassa Lignocelulósica e Desenvolvimento Vegetativo .............. 28

2.3.4 Desconstrução Enzimática da Fração Polissacarídea da Biomassa ............................... 29

2.4 Análise Multivariada Aplicada a Síntese da Biomassa Lignocelulósica ......................... 30

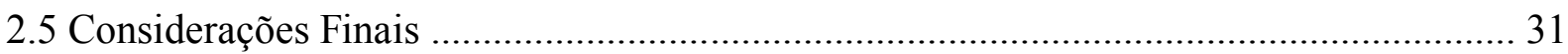

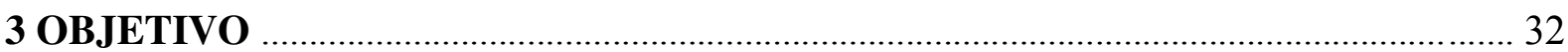

\section{Capítulo 2}

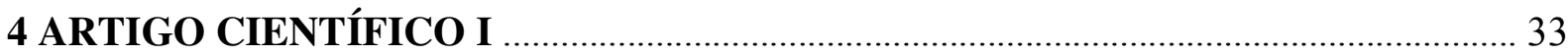

\section{Capítulo 3}

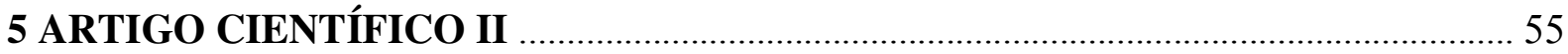

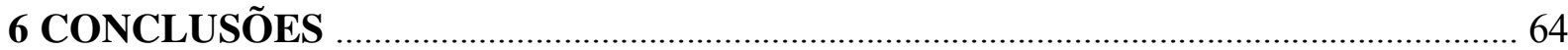

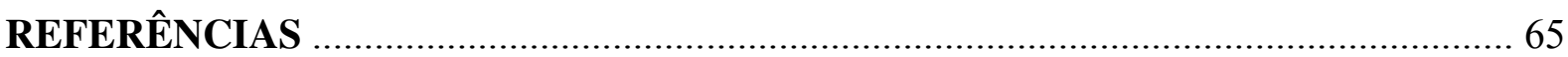





\section{Capítulo 1: Introdução, revisão bibliográfica e objetivos}

\section{INTRODUÇÃO}

Híbridos de Saccharum tem sido tradicionalmente desenvolvidos buscando aptidões como o elevado acúmulo de sacarose, a elevada produtividade no campo, a resistência às pragas decorrentes do plantio em monoculturas, a resistência à seca e a adaptabilidade a diferentes tipos de solo (LAKSHMANAN et al., 2005; WACLAWOVSKY et al., 2010; LOUREIRO et al., 2011). Todo este desenvolvimento tem sido destinado para a produção de açúcar e etanol. A conversão do bagaço de cana-de-açúcar em substâncias de alto valor agregado ou etanol celulósico são novos rumos para a indústria sucroalcooleira no século XXI (RAGAUSKAS et al., 2014; SHELDON, 2014). No entanto, a desconstrução da biomassa lignocelulósica em polímeros majoritários como a celulose, hemicelulose e lignina, assim como a transformação da fração polissacarídica do bagaço de cana em monossacarídeos requer uma série de processos que apresentam dificuldades técnicas e econômicas (RAGAUSKAS et al., 2014).

Diversas estratégias promovem a desconstrução e facilitam a hidrólise enzimática do bagaço da cana-de-açúcar, inclusive, o pré-tratamento químico e a utilização de híbridos com baixo teor de lignina, alto teor de glucanas mistas (MLG) e baixo teor de celulose cristalina (PARK et al., 2010; COSTA et al., 2016). No entanto, até o presente momento (final da década de 2010), tanto no Brasil como em outros países lideres no setor sucroalcooleiro, não existem híbridos comerciais de Saccharum com aptidão para produção de sacarose e simultaneamente acúmulo de biomassa com baixa recalcitrância. Um esforço recente desenvolvido neste sentido foi liderado pela RIDESA e resultou no desenvolvimento de híbridos com características favoráveis (e.g. baixo teor de lignina) às novas perspectivas de utilização do bagaço da cana-de-açúcar (LOUREIRO et al., 2011; MASARIN et al., 2011).

A digestibilidade enzimática da biomassa lignocelulósica dos híbridos RIDESA mencionados anteriormente foi avaliada por Masarin et al. (2011), Masarin et al. (2013), Costa et al. (2013), Mendes et al. (2015), Laurito-Friend et al. (2015) e Costa et al. (2016). Os 6 estudos demonstraram que o alto teor de lignina possui correlação inversa com a digestibilidade enzimática da biomassa. A presença de áreas extensas de aglomerados vasculares nos entrenós também se mostrou inversamente correlacionada com a digestibilidade enzimática da biomassa (COSTA et al., 2013). Por outro lado, teores elevados 
de MLG's e baixo teor de celulose cristalina se correlacionaram com amostras de biomassa facilmente digeríveis com enzimas hidrolíticas (COSTA et al., 2016).

Os estudos com os híbridos RIDESA, anteriormente mencionados, juntamente com o estudo da deposição de lignina nos entrenós de cana-de-açúcar descritos por Bottcher et al. (2013) sugerem que a recalcitrância do bagaço da cana-de-açúcar aumenta durante o desenvolvimento vegetativo. De fato, há evidências de que as alterações na partição de carbono no decorrer do desenvolvimento vegetativo da cana-de-açúcar são responsáveis pelo aumento na recalcitrância da biomassa (DROUET; PAGÈS, 2003; WANG et al., 2013). Especificamente, o acúmulo de sacarose e a alocação de lignocelulose ocorrem de forma simultânea até a saturação de sacarose em entrenós maduros (WANG et al., 2013). Após a saturação de sacarose, a alocação de lignocelulose, especialmente de lignina, não é interrompida e condiciona o espessamento e o aumento da lignificação das paredes celulares, especialmente das fibras do esclerênquima (WILSON; HATFIELD, 1997; LINGLE; THOMSON, 2012; POELKING et al., 2015).

Os fatores que afetam a recalcitrância da biomassa de gramíneas e do bagaço da canade-açúcar ao longo do desenvolvimento vegetativo são bem conhecidos (GRABBER, 2005, SIQUEIRA et al., 2011; LINGLE ; THOMSON, 2012; SIQUEIRA et al. 2013; CASS et al., 2016). Recentemente, outros fatores foram identificados, especificamente o elevado teor de MLG e os baixos teores de ácidos hidroxicinâmicos promovem um aumento da digestibilidade enzimática da biomassa (VEGA-SÁNCHEZ et al., 2013 ; COSTA et al., 2016). Visando identificar um perfil de maturação de cana-de-açúcar que condicione um alto padrão de saturação de sacarose e uma baixa taxa de lignificação da biomassa, esta pesquisa utilizou 4 híbridos para avaliar como ocorre o desenvolvimento da recalcitrância e o acúmulo de sacarose ao longo de diferentes estágios de desenvolvimento vegetativo dos entrenós. Esta pesquisa descreve de forma inédita o perfil de acúmulo de carboidratos não estruturais e estruturais em híbridos de Saccharum desenvolvidos dentro do contexto das novas perspectivas de utilização da biomassa do bagaço de cana-de-açúcar. A caracterização do acúmulo de sacarose e da deposição de lignocelulose junto com a avaliação da digestibilidade enzimática da biomassa ao longo do caule da cana-de-açúcar é importante, pois permite averiguar a possível existência de um perfil de maturação que condicione aptidão dupla, saturação de sacarose e acúmulo de biomassa com baixa recalcitrância.

Esta tese segue estruturada na seguinte forma: introdução e contextualização sobre o tema revisão bibliográfica sobre o acúmulo da biomassa e sobre o desenvolvimento da recalcitrância da biomassa à hidrólise enzimática em gramíneas, incluindo a cana-de-açúcar e 
o objetivo geral da tese (Capítulo 1); dois artigos científicos que incluem introduções específicas, metodologia experimental, resultados e discussão (Capítulos 2 e 3) e uma conclusão geral sobre a tese desenvolvida além das referências bibliográficas apresentadas em conjunto para evitar a repetição de referências em cada capítulo.

\section{REVISÃO BIBLIOGRÁFICA}

\subsection{Morfologia e Anatomia da Cana-de-açúcar}

O caule da cana-de-açúcar é composto por uma série de subunidades, os fitômeros (Figura 1.1); cada fitômero é constituído por uma lâmina foliar e bainha, nó e entrenó, além da gema axilar localizada abaixo do ponto de inserção da bainha foliar (BONNETT, 2013). A formação e o alongamento dos entrenós da cana-de-açúcar ocorrem simultaneamente ao processo de diferenciação dos fitômeros a partir do meristema apical (MOORE; MOOSER 1995). Portanto, o caule da cana é composto por entrenós em estágios progressivos de desenvolvimento vegetativo.

Figura 1.1 Arranjo estrutural dos fitômeros em um caule de cana-de-açúcar. A) Representação esquemática de um fitômero, B) Representação esquemática de um perfilho de cana-de-açúcar composto por uma série de fitômeros em estágios de desenvolvimento sucessivos

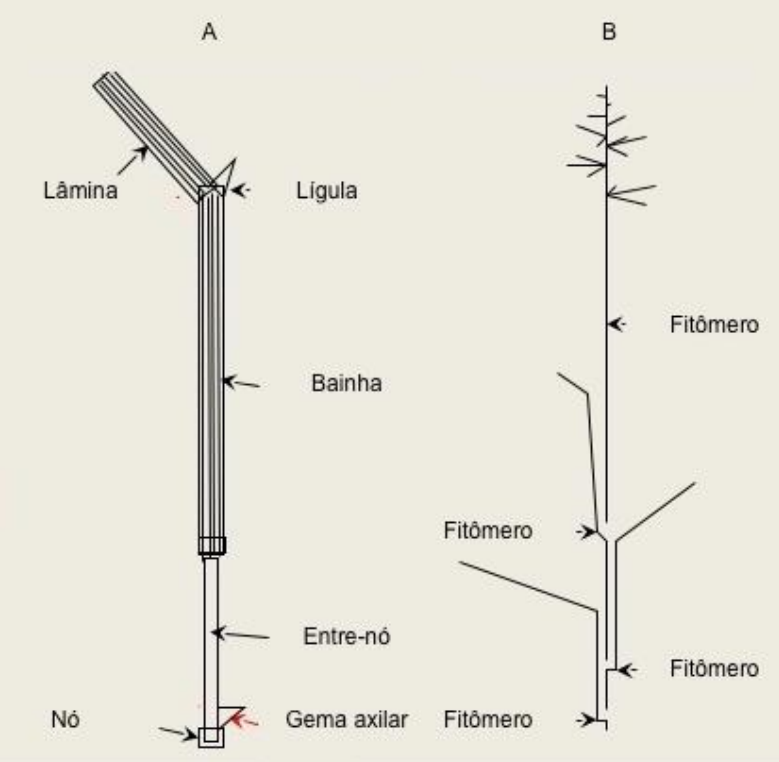

Fonte: Adaptado de Moore; Moser (1995) 
Durante o desenvolvimento vegetativo dos fitômeros, podemos observar o aumento da proporção de lignina na composição da biomassa (BOTTCHER et al., 2013). Este fenômeno influi fortemente sobre a recalcitrância da biomassa à hidrolise enzimática. Portanto, o processo de acúmulo de lignina deve ser considerado na busca de híbridos de Saccharum com aptidão dupla, ou seja, elevada produção de sacarose e baixa recalcitrância da biomassa.

O entrenó da cana-de-açúcar é composto por células epidérmicas, meristemáticas, parenquimáticas, vasculares e células com função estrutural (MOORE; MOSER 1995). Especificamente, podemos fracionar o entrenó da cana-de-açúcar em 3 regiões: a medula, o cortéx e a casca. A região da medula é composta predominantemente pelo parênquima, apesar de existirem aglomerados vasculares nesta região (BRIENZO et al., 2016). Por outro lado, a região do córtex apresenta um predomínio de células do sistema vascular em comparação as células parenquimáticas (COSTA et al., 2016; BRIENZO et al., 2016). Os aglomerados vasculares são formados por fibras do esclerênquima e os vasos xilemáticos, além de pequenas regiões contendo células ativas do floema. A casca contém células epidérmicas e um anel contínuo de células corticais (MOORE; MOSER, 1995).

As características anatômicas e a composição química das células do entrenó e a recalcitrância da biomassa do bagaço da cana-de-açúcar estão correlacionados. Especificamente, a recalcitrância do bagaço da cana-de-açúcar é condicionada pela predominância de aglomerados vasculares ricos em fibras do esclerênquima lignificadas (DE SOUZA et al., 2013; COSTA et al., 2013; COSTA et al., 2016). As células do parênquima são delgadas e não apresentam deposição acentuada de compostos poliméricos recalcitrantes como a lignina (SANT'ANNA et al., 2013).

\subsection{Fotossíntese, acúmulo de Sacarose e Lignocelulose}

\subsubsection{Fotossíntese}

A fotossíntese, e as dinâmicas de partição e acúmulo de fotoassimilados e derivados de fotoassimilados, são processos bem descritos tanto para gramíneas que apresentam via de fixação de carbono $\mathrm{C} 3$ como $\mathrm{C} 4$, inclusive a cana-de-açúcar que é uma gramínea do tipo C4 (GOWIK ; WESTHOFF, 2011). Gramíneas C4, em condições de alta temperatura, alta taxa de luminosidade, baixa taxa de condutância estomática e/ou baixa concentração atmosférica de $\mathrm{CO}_{2}$, possuem maior capacidade de produção de biomassa em comparação com gramíneas C3 devido ao padrão anatômico foliar "Kranz" (SAGE et al., 2012) (Figura 1.2). A anatomia 
foliar Kranz caracteriza a cooperação entre dois tipos de células fotossinteticamente ativas: as células do mesófilo e as células da bainha do feixe vascular (EDWARDS; VOZNESENSKAYA, 2010). Essencialmente, a anatomia Kranz garante um ambiente saturado de $\mathrm{CO}_{2}$ e consequentemente reduz a fotorrespiração nas células onde o ciclo de Calvin acontece, ou seja, nas células da bainha do feixe vascular (SAGE; ZHU, 2011).

Figura 1.2 Representação esquemática da fotossíntese e da estrutura foliar de gramíneas C3 e C4

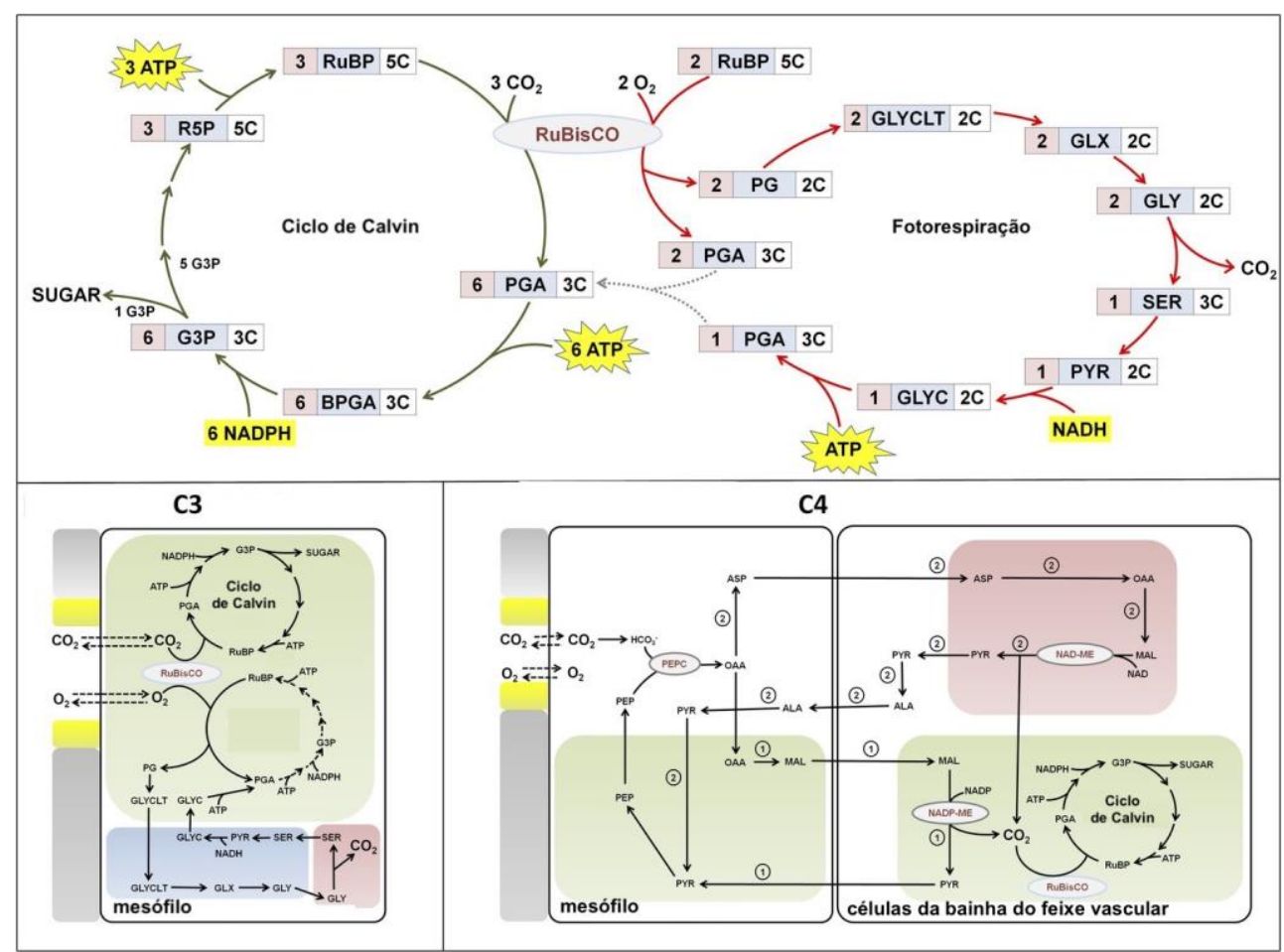

Fonte: Adaptado de Gowik; Westhoff (2011)

Em gramíneas $\mathrm{C} 4$, a fixação enzimática de $\mathrm{CO}_{2}$ junto a enzima PEP carboxilase (PEP) ocorre nos cloroplastos das células do mesófilo foliar e resulta na produção de um ácido orgânico de 4 carbonos, o ácido oxaloacético (GOWIK; WESTHOFF, 2011). O ácido oxaloacético é convertido em malato e posteriormente difunde para as células da bainha do feixe vascular (GOWIK; WESTHOFF, 2011). A descarboxilação dos ácidos de 4 carbonos em $\mathrm{CO}_{2}$ nas células da bainha do feixe vascular permite a fixação do $\mathrm{CO}_{2}$ junto a enzima ribulose-1,5-bifostato carboxilase/oxigenasse (RUBISCO) no ciclo de Calvin, resultando na produção de fotoassimilados de 3 carbonos (GOWIK; WESTHOFF, 2011). Nas células da bainha do feixe vascular, os fotoassimilados de 3 carbonos são utilizados para a síntese de uma série de compostos químicos, incluindo lipídios, amino ácidos, e precursores da sacarose, celulose e hemiceluloses (WANG et al., 2013). 


\subsubsection{Síntese de Sacarose}

A sacarose é sintetizada no aparato foliar e nos tecidos que armazenam derivados de fotoassimilados, ou seja, os tecidos-dreno como o parênquima (WANG et al., 2013). No citosol das células foliares, as conversões de fotoassimilados de 3 carbonos produzidos no ciclo de Calvin em glicose-uridina-difosfato (uridine diphosphate glucose - UDP-Glc) e frutose-6-fostato são críticas para a produção de sacarose (TURNER; BOTHA, 2002). Após esta etapa, as enzimas sucrose-P-synthase (SPS) e sucrose-P-phosphatase (SPP) promovem a síntese da sacarose (UYS et al., 2007; VERMA et al., 2011). A enzima SPS utiliza UDP-Glc e frutose-6-fostato como substratos para a síntese de sacarose-6-fostato. Em contrapartida, a enzima SPP sintetiza sacarose por meio da retirada de ortofostato (Pi) da molécula sacarose-6fostato (UYS et al., 2007; VERMA et al., 2011) (Figura 1.3).

Figura 1.3 Fluxograma da síntese de sacarose na cana-de-açúcar

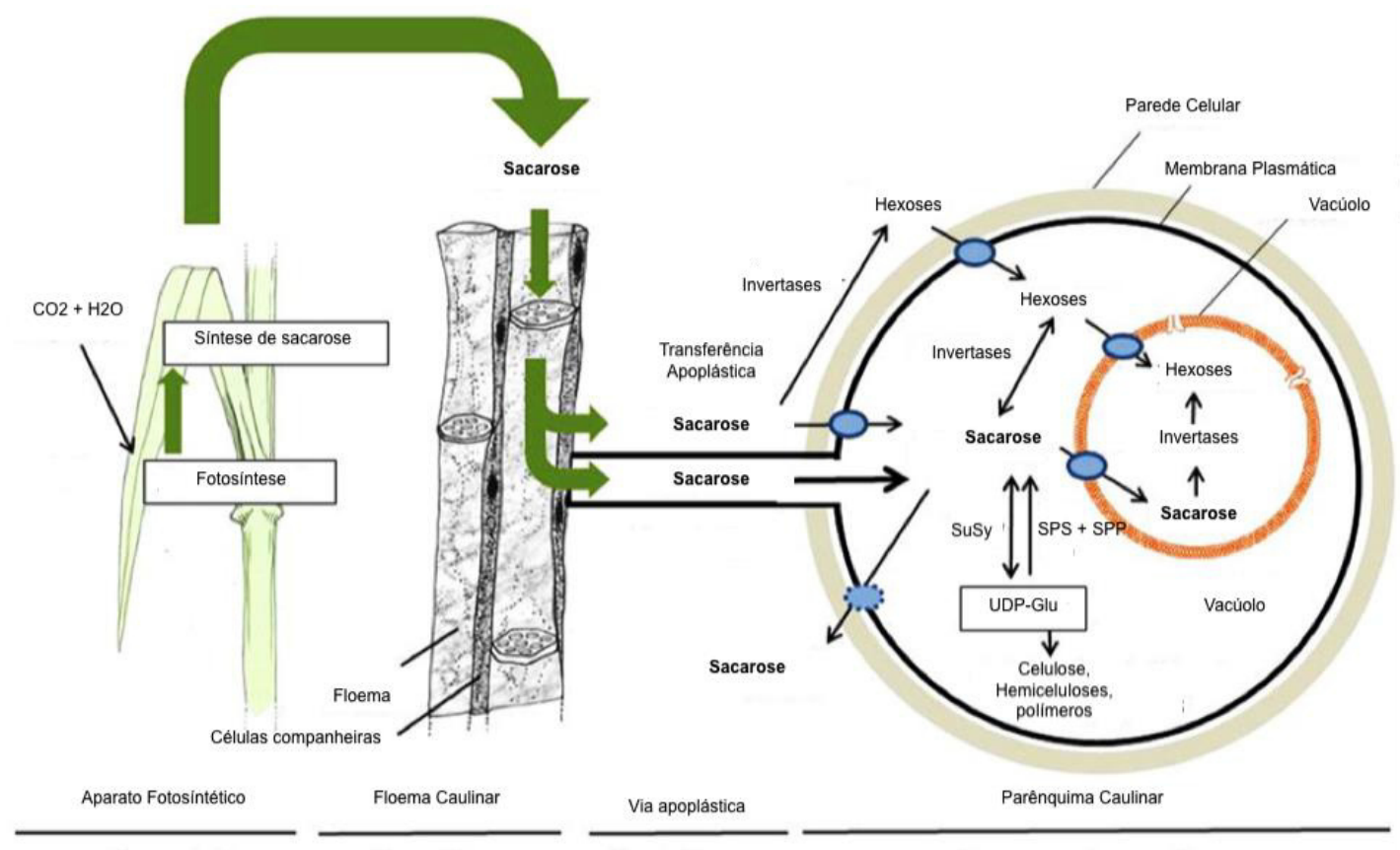

Fonte: Adaptado de Wang et al. (2013)

A sacarose sintetizada no complexo foliar da cana-de-açúcar é translocada pelo floema até os tecidos-dreno, ou seja, as células parenquimáticas do entrenó (WANG et al., 2013). No parênquima caulinar, a sacarose é armazenada em vacúolos (WANG et al., 2013). Após a deposição e armazenamento da sacarose no interior dos vacúolos das células parenquimáticas, 
a sacarose permanece sujeita as reações de degradação-síntese (WANG et al., 2013). A degradação enzimática da sacarose devido a ação das invertases produzem glicose e frutose que podem ser novamente utilizadas na síntese de sacarose (MAO; WANG, 2006). A reação reversível de degradação-síntese catalisada pela enzima sucrose synthase (SuSy), converte sacarose em UDP-Glc e frutose, e vice-versa (LINGLE; TEW, 2008). As reações de síntese catalisadas pelas enzimas SPS e SPP que ocorrem no aparato foliar, também convertem UDPGlc e frutose-6-fostato em sacarose nas células parenquimáticas (WANG et al., 2013). Portanto, a sacarose pode ser sintetizada tanto no aparato fotossintético como no parênquima caulinar da cana-de-açúcar.

\subsubsection{Síntese de Carboidratos Estruturais}

Em adição à sacarose, o carbono fixado durante a fotossíntese é alocado na forma de glucanas, hemiceluloses e lignina nas paredes das células vegetais (YANG et al., 2013). As vias metabólicas de síntese de carboidratos poliméricos da parede celular envolvem a conversão de açúcares e fosfato de açúcares em nucleotídeo-açúcares, como uridine diphosphate galactose (UDP-Gal), uridine diphosphate mannose (UDP-Man), uridine diphosphate glucuronic acid (UDP-GlcA), uridine diphosphate galacturonic acid (UDPGalA), uridine diphostate xylose (UDP-Xyl), uridine diphostate arabinose (UDP- - -Ara) e UDP-Glc (GIBEAUT, 2000).

Nucleotídeo-açúcares, celulose sintases (CesA's) e enzimas acessórias certamente descrevem a síntese de celulose (SOMERVILLE, 2006). No entanto, a síntese de celulose também é auxiliada por glicosiltranferases (GT's) e até mesmo pela ação de primers lipoglicanos, como sisterol- $\beta$-glucoside (PENG et al., 2002; GUERRIERO; FUGELSTAD; BULONE, 2010). A síntese de outras glucanas e hemiceluloses consideram essencialmente nucleotídeo-açúcares junto a ação de cellulose synthases like (Csl's) e a GT's, respectivamente (SCHELLER; ULVSKOV, 2010). As enzimas CesA's são responsáveis pela síntese de celuloses (SOMERVILLE, 2006; MUTWIL et al., 2008). Cada complexo de síntese de microfibrilas de celulose, localizado na membrana plasmática das células, é composto por 6 subunidades "rosetas", e cada roseta possui 6 proteínas CesA (DOBLIN et al., 2002). Em adição a celulose sintase, a síntese de celulose é auxiliada por primers lipoglicanos e pelas enzimas SuSy e Korrigan (KOR) celulase (PENG et al., 2002; GUERRIERO; FUGELSTAD; BULONE, 2010) (Figura 1.4). A enzima SuSy converte moléculas de sacarose em UDP-Glc e frutose, e consequentemente, abastece o complexo de rosetas com os 
precursores UDP-Glc utilizados na síntese de celulose (HAIGLER et al., 2001). A enzima KOR verifica, edita e elimina cadeias defeituosas de celuloses assim como controla o grau de cristalização da celulose (ROBERT et al., 2004). Alterações no perfil de amino ácidos e na funcionalidade da enzima KOR em Arabidopsis evidenciaram que enzimas defeituosas reduzem o grau de cristalização da celulose (HIS et al., 2001).

Figura 1.4 Diagrama da síntese de celulose

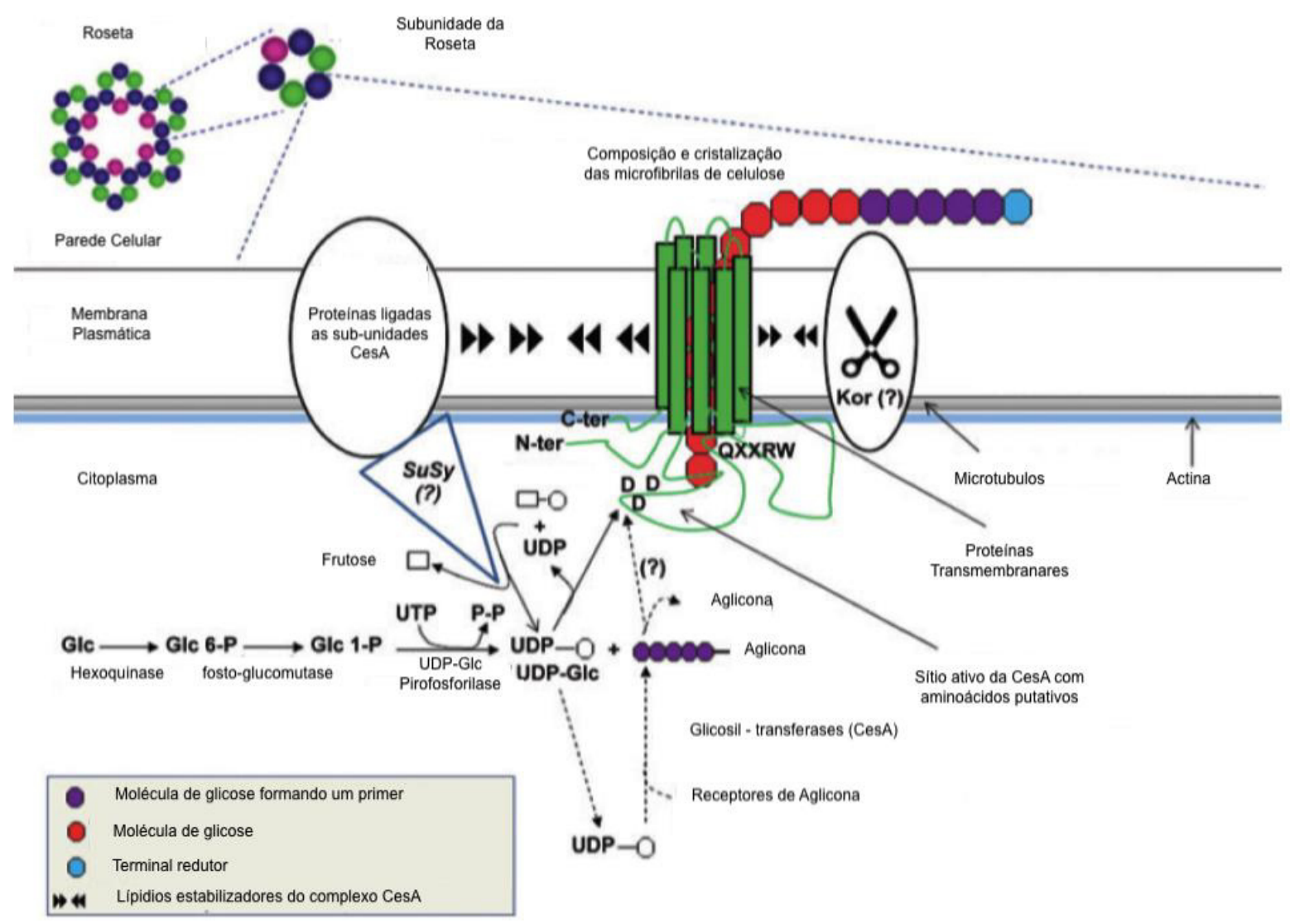

Fonte: Adaptado de Guerriero; Fugelstad; Bulone, (2010)

A síntese de glucanas, incluindo glucomananas e glucanas mistas (MLG's), e a síntese de hemiceluloses, como xiloglucanas, glucuronoxilanas (GX's) e glucuronoarabinoxilanas (GAX's), ocorrem em regiões específicas do Complexo de Golgi (SUZUKI et al., 2006; DRIOUICH et al., 2012). As enzimas Csl's sintetizam glucomanas, xiloglucanas e MLG's utilizando UDP-Man, UDP-Xyl e UDP-Glc (CARPITA; GIBEAUT, 1993; BURTON et al., 2006). A síntese das cadeias centrais de GX's e GAX's ocorrem a partir de UDP-Xyl e UDPGlc pela ação de diversas glicosiltransferases (CAO et al., 2008; OIKAWA et al., 2013) (Figura 1.5). As enzimas GT's também decoram as cadeias centrais de GX's e GAX's com 
arabinose e ácido glucorônico ou 4-O-metil-glucorônico utilizando UDP-Ara e UDP-GlcA como substratos respectivamente (FAIK, 2010).

Figura 1.5 Diagrama da sintese de hemiceluloses

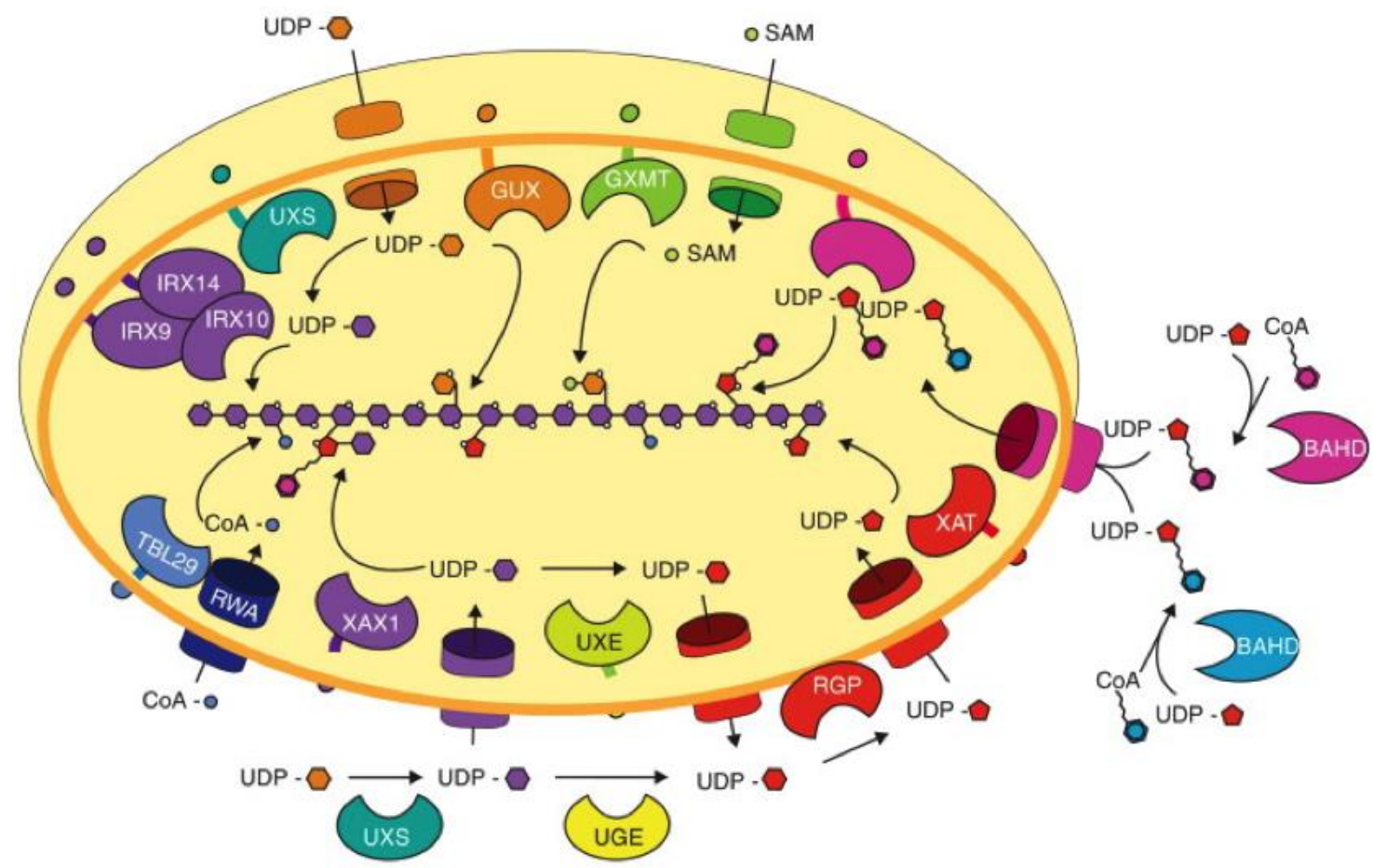

Fonte: Rennie; Scheller (2014).

\subsubsection{Síntese de Lignina e Ácidos Hidroxicinâmicos}

A lignina e os ácidos hidroxicinâmicos: ferúlico e paracumárico, também são drenos de carbono fotossintético (FRANK et al., 2004, HALPIN, 2019). A lignina e os ácidos hidroxicinâmicos são sintetizados a partir da fenilalanina produzida na via de síntese de chiquimato (HERRMANN et al., 1995; GRABBER, 2019). A conversão de frutose-1,6bifostato em fosfoenolpiruvato durante a glicólise, e a síntese de fenilalanina a partir de fosfoenolpiruvato e eritrose-4-fosfato são etapas essenciais para a síntese de lignina e ácidos hidroxicinâmicos (VANHOLME et al., 2010, VANHOLME et al., 2019).

Os ácidos hidroxicinâmicos são sintetizados a partir da fenilalanina antes da síntese dos monolignóis que compõem a lignina (HUMPHREYS; CHAPPLE, 2002) (Figura 1.6). O ácido paracumárico é sintetizado a partir da fenilalanina pela ação das enzimas phenylalanine ammonia liase (PAL) e cinnmate 4-hydroxylase $(\mathrm{C} 4 \mathrm{H})$, em contrapartida, as enzimas pcoumarate 3-hydroxylase $(\mathrm{C} 3 \mathrm{H})$ e catechol-O-methyl transferase (COMT) sintetizam o ácido 
ferúlico a partir do ácido paracumárico (MACDONALD; D'CUNHA, 2007; FRASER; CHAPPLE, 2011). Os álcoois mencionados anteriormente, especificamente, coniferil, sinapil, e p-cumaril, são precursores dos monômeros hidrocinamoil $(\mathrm{H})$, siringil $(\mathrm{S})$, e guaiacil $(\mathrm{G})$ respectivamente (LI et al., 2001; VANHOLME et al., 2010). As enzimas 4-coumarate:CoA ligase (4CL), cinnamoyl-CoA reductase (CCR), e cinnamyl alchool dehydrogenase (CAD), sintetizam hidroxicinamoil a partir do ácido paracumário (WAGNER et al., 2007; ZHAO et al., 2013). As enzimas 4CL, CCR, CAD, peroxidases (PER) e lacases (LAC), sintetizam guaiacil a partir do ácido ferúlico (STERJIADES et al., 1993; HALPIN, 2019). O monolignol siringil também é sintetizado a partir do ácido ferúlico pela ação das enzimas ferulate 5hydroxylase (F5H), COMT, 4CL, CCR, CAD, peroxidases e lacases (STERJAADES et al., 1992; ZHAO et al., 2013, HALPIN, 2019).

Figura 1.6 Via de biossíntese de monolignols em plantas vasculares. a) Enzimas envolvidas na síntese de lignina. b) Marcação da lignina no caule de Panicum spp por floroglucinol. c) Visualização da deposição de lignina por fluorescência após excitação no UV em um corte do caule de Medicago truncatula

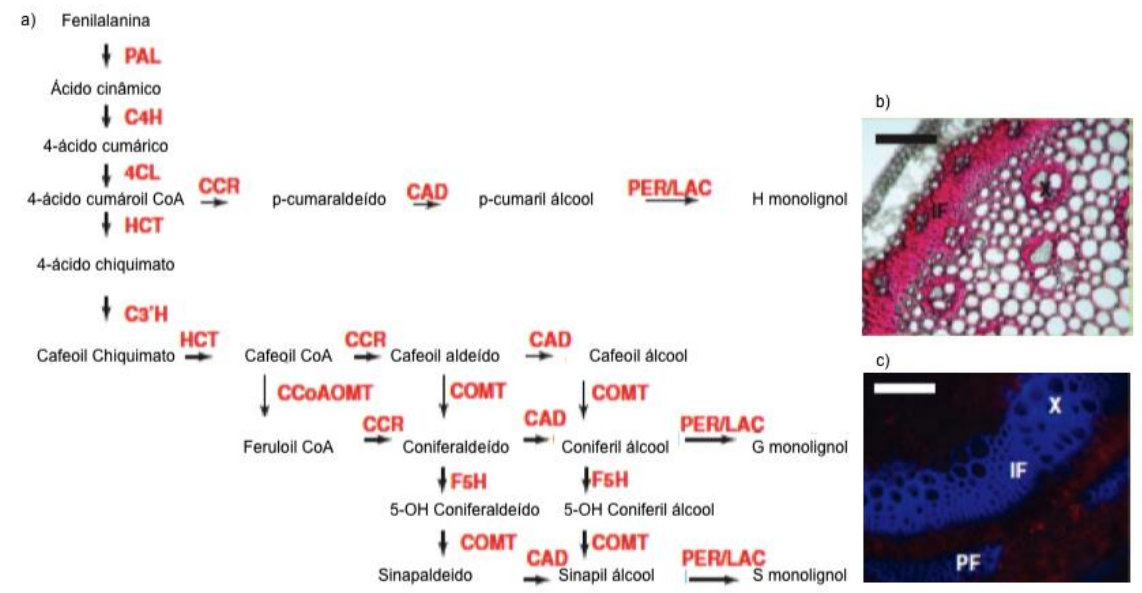

Fonte: Adaptado de Vanholme et al. (2019)

\subsection{Matriz Química, Desconstrução e Recalcitrância da Biomassa Lignocelulósica}

\subsubsection{Matriz Química da Parede Celular}

A parede primária é constituída essencialmente de hemiceluloses, pectina, e glucanas como a celulose, enquanto que a parede secundária caracteriza-se pelo acúmulo de lignina juntamente aos carboidratos estruturais (SOMERVILLE et al., 2004; COSGROVE, 2005). A síntese da parede primária ocorre simultaneamente ao processo de crescimento e expansão 
celular (COSGROVE, 2012; PARK; COSGROVE, 2012). A parede secundária é sintetizada somente após o término do crescimento e expansão de células que apresentam função estrutural e condutora de água, como as fibras do esclerênquima e os vasos xilemáticos, respectivamente (SALMÉN, 2004; COSGROVE, 2012). Em adição as diferenças na composição química entres as paredes primárias e secundárias, a espessura, o número de camadas, e a rigidez da parede secundária é maior em comparação a parede primária (COSGROVE, 2012).

As microfibrilas de celulose que compõem a parece celular são constituídas por inúmeras cadeias lineares de anidroglicoses (MOON et al., 2011). Na celulose, as moléculas de glicose permanecem unidas por ligações glicosídicas entre os carbonos 1 e 4 com configuração $\beta$ (MOON et al., 2011). Em cada anidro-monômero de glicose que compõe a celulose, existem 3 hidroxilas que condicionam características estruturais importantes tanto à cadeia como às microfibrilas de celulose (HABIBI et al., 2010). Especificamente, as pontes de hidrogênio intra-cadeia entre hidroxilas e entre hidroxilas e o oxigênio do anel glicosídico condicionam a conformação linear da celulose (KLEMM et al., 2005). Em contrapartida, as forças de van der Walls e as pontes de hidrogênio entre hidroxilas de cadeias de celulose adjacentes garantem a formação e a rigidez das microfibrilas de celulose (KLEMM et al., 2005). A conformação das pontes de hidrogênio entre as cadeias de celulose também determinam o tipo de estrutura cristalina deste polímero (NISHIYAMA et al., 2003; ŠTURCOVÁ et al., 2004) (Figura 1.7).

Figura 1.7 Estrutura química da celulose

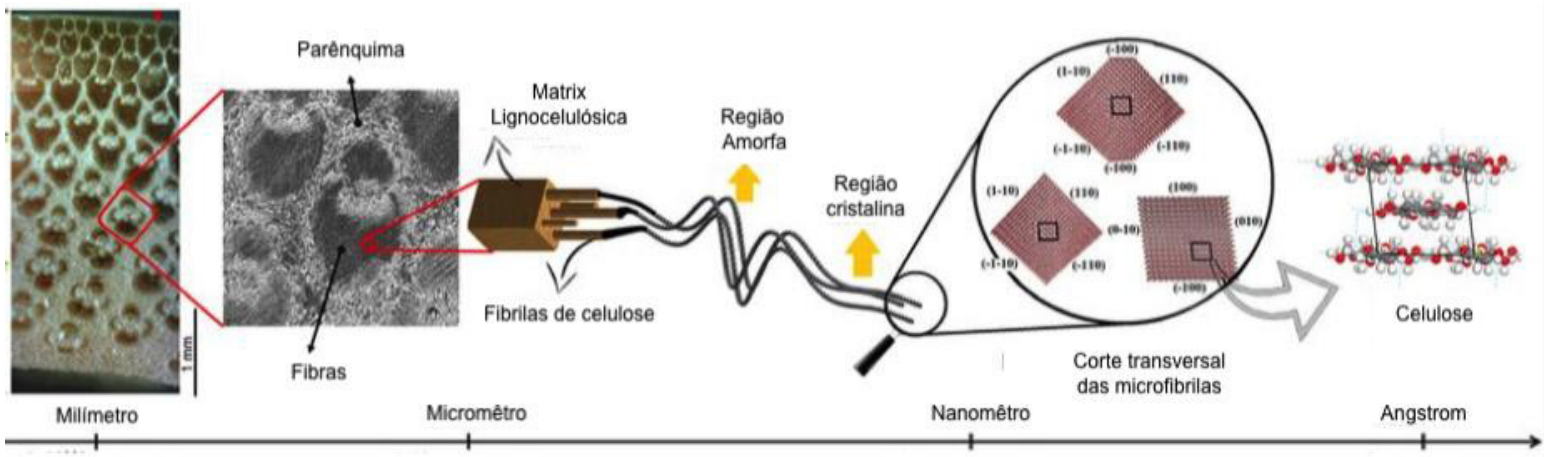

Fonte: Adaptado de Youssefian; Rahbar (2015)

As mixed linkage glucans (MLG's) são glucanas essencialmente encontradas em gramíneas (SØRENSEN et al., 2008; VEGA-SANCHEZ et al., 2013). MLG's são constituídas por glicoses unidas por ligações 1-4 $\beta$ e 1-3 $\beta$ (LAZARIDOU et al., 2007). 
Especificamente, MLG's são constituídas por polímeros de celotrioses e celotetraoses unidos por ligações 1-3 $\beta$ (LAZARIDOU et al., 2007). Estruturalmente, MLG's não são polímeros lineares de glicoses justamente devido as deformações na estrutura linear promovidas pelas ligações 1-3 $\beta$ (BURTON et al., 2006; CARPITA, 2011) (Figura 1.8). A presença de MLG's nas paredes de células em crescimento e células com parede secundárias, assim como o acúmulo de MLG's no endosperma de gramíneas, sugerem que este polissacarídeo possui função estrutural e de armazenamento de energia (VEGA-SÁNCHEZ et al., 2012).

Figura 1.8 Estrutura química da MLG

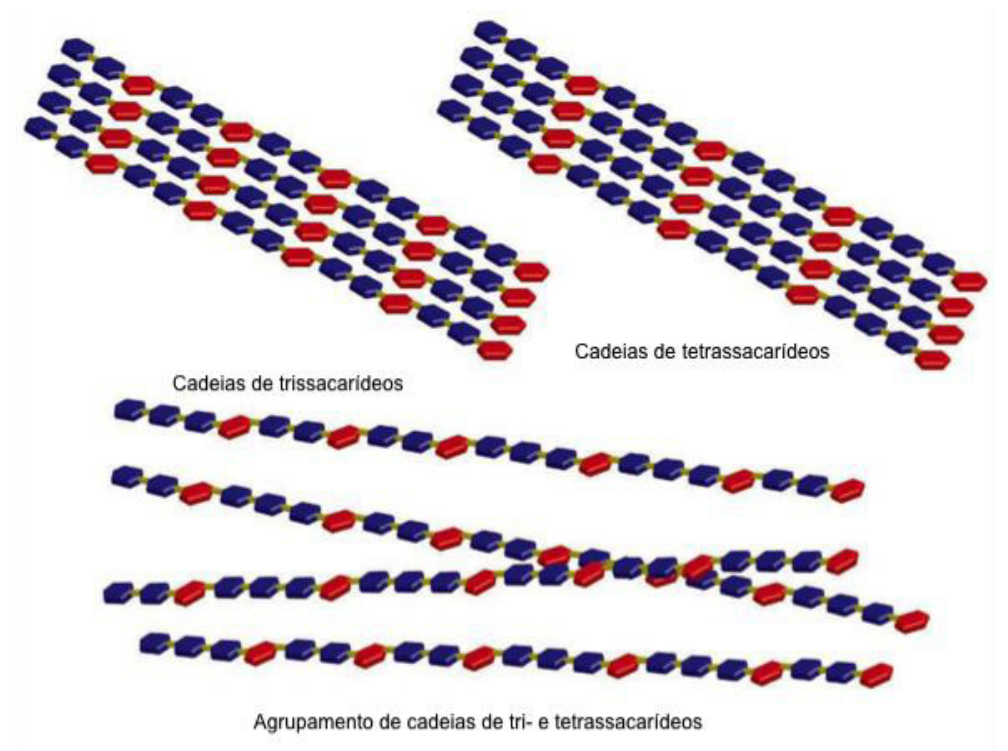

Fonte: Adaptado de Burton et al. (2010)

Xiloglucanas são hemiceluloses comumente encontradas nas paredes primárias; xiloglucanas são constituídas por glicoses unidas por ligações 1,4- $\beta$ (FRY, 1989) (Figura 1.9). Xiloglucanas possuem decorações na cadeia central de glicoses com resíduos de xilose, galactose, arabinose, e até mesmo fucose (PAULY et al., 2001). As xiloglucanas podem ser classificadas segundo a conformação das ramificações dos resíduos de xilose (VINCKEN et al., 1997). Especificamente, as xiloglucanas podem ser do tipo XXXG ou XXGG (SCHULTINK et al., 2014; PARK; COSGROVE, 2015). As xiloglucanas XXXG apresentam 3 das 4 moléculas de glicose substituídas com resíduos de xilose (SCHULTINK et al.,2014). As xiloglucanas XXXG são predominantes na maioria das eudi- e mono-cotiledôneas (HUISMAN et al., 2000). Em contrapartida, as xiloglucanas XXGG são encontradas essencialmente em gramíneas (HSIEH et al., 2009). Xiloglucanas também podem ser 
acetiladas, ou seja, xiloglucanas do tipo XXXG podem apresentar resíduos como 6-O-acetil galactose, 5-O-acetil arabinose e 6-O-acetil glicose (BUSSE-WICHER et al., 2014).

Figura 1.9 Estrutura química da Xiloglucana

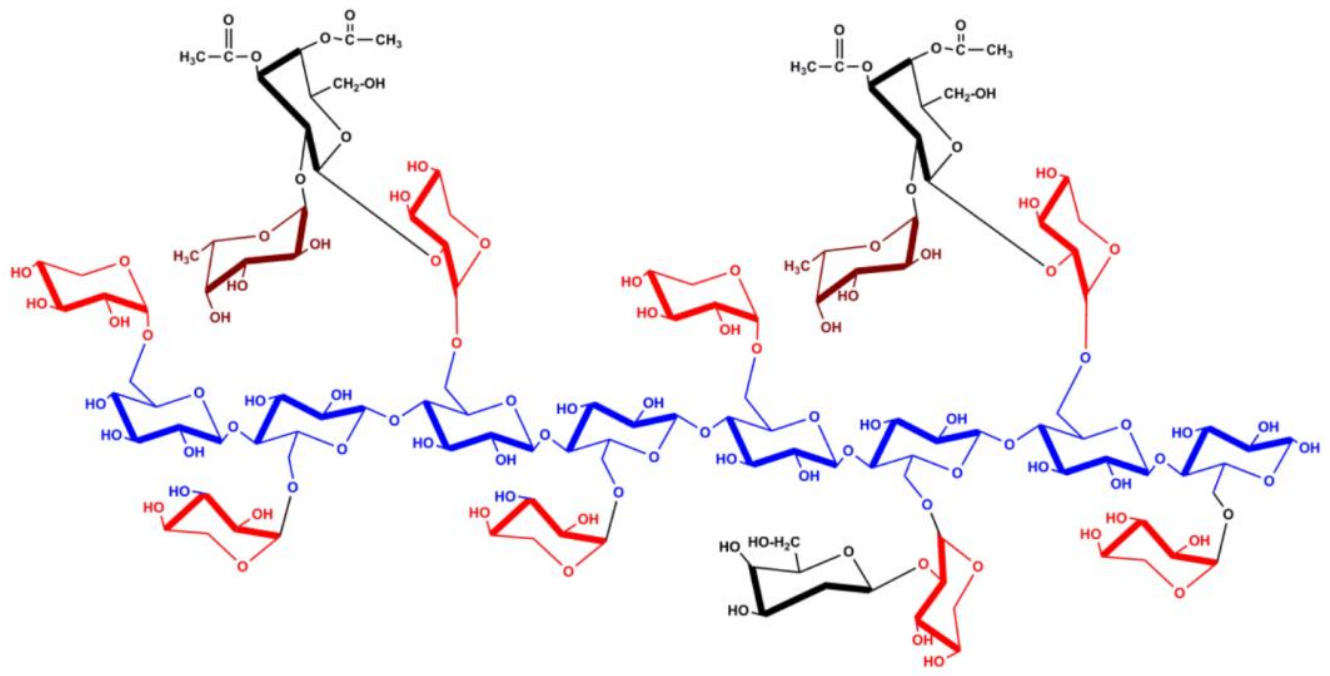

Fonte: Ochoa-Villarreal et al. (2012)

Glucuronoxilanas (GX) são hemiceluloses predominantes nas paredes secundárias de angiospermas e gramíneas; GX's são constituídas por xiloses unidas por ligações glicosídicas do tipo 1,4- $\beta$ (LEE et al., 2010). Glucuronoxilanas apresentam decorações na cadeia central de xilose com os ácidos metil glucurônico e 4-O-metil-glucurônico (CHONG et al., 2014). Glucuronoxilanas compõem a maior fração das hemiceluloses em angiospermas arbóreas, inclusive espécies do gênero Eucalyptus (PINTO, P. C.; EVTUGUIN, D. V.; PASCOALNETO, 2005). Em gramíneas, as hemiceluloses glucuronoarabinoxilanas (GAX) apresentam composição química similar as glucuroxilanas das espécies arbóreas hardwood (PEÑA et al., 2016). Especificamente, as hemiceluloses GAX apresentam composição química da cadeia principal idêntica as GX, sendo que a diferença essencial entre GAX e GX, é a presença de resíduos de arabinose na hemicelulose GAX (SCHELLER et al., 2010) (Figura 1.10). 
Figura 1.10 Estrutura química da GAX

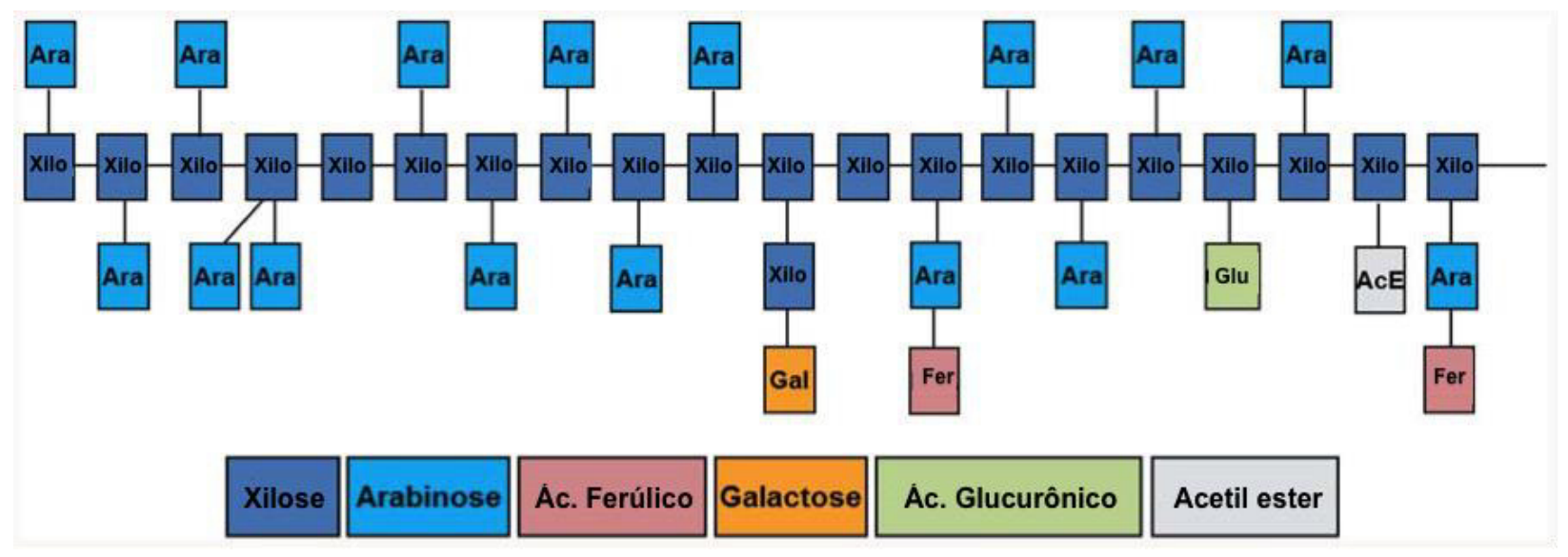

Fonte: Adaptado de Burton; Fincher (2012)

A lignina é um polímero natural de estrutura complexa (Figura 1.11). Esta estrutura complexa é composta por subunidades deste polímero que se ligam entre si por ligações do tipo éter e entre carbonos (HALPIN et al., 2019; HATCHFIELD et al., 2019). A lignina esta comumente associada a carboidratos estrurais como as hemiceluloses (RALPH; LAPIERRE; BOERJAN, 2019). No caso das gramíneas, os ácidos hidroxicinâmicos (cumárico e ferúlico) realizam a ligação entre a lignina e as hemiceluloses (RALPH; LAPIERRE; BOERJAN, 2019). O ácido ferúlico se associa a lignina por meio de ligações éter, enquanto que este ácido se associa as hemiceluloes por ligações éster (RALPH; LAPIERRE; BOERJAN, 2019). 
Figura 1.11 Estrutura complexa da lignina em diversas grupos vegetais. a) Giminosperma. b) Angiospermas e c) Monocotiledoneas

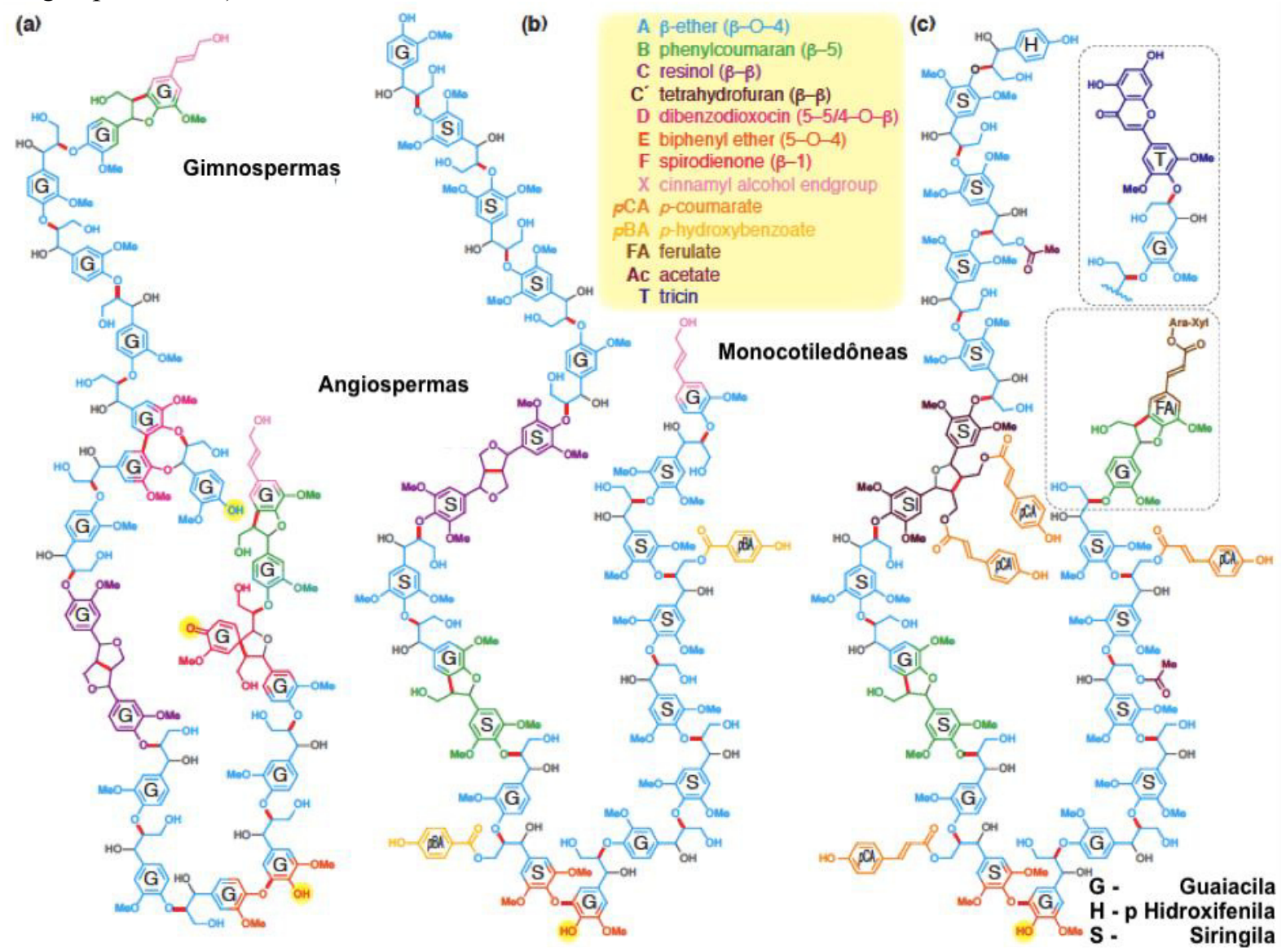

Fonte: Adaptado de Ralph; Lapierre; Boerjan (2019)

\subsubsection{Recalcitrância da Biomassa Lignocelulósica e Pré-tratamento Químico}

Os híbridos de cana-de-açúcar conhecidos como canas-energia possuem maior potencial de produção de etanol celulósico em comparação aos híbridos desenvolvidos para a produção de açúcar-etanol devido a maior produção de biomassa lignocelulósica (KIM; DAY, 2011; LOUREIRO et al., 2011). No entanto, a produção de etanol celulósico oriunda de híbridos ricos em sacarose ou híbridos cana-energia possui ineficiências devido a recalcitrância da biomassa do bagaço (SCORDIA; COSENTINO; JEFFRIES, 2010; REZENDE et al., 2011). O pré-tratamento da biomassa é uma estratégia para aumentar a eficiência da conversão da fração polissacarídica do bagaço em monômeros (CHEN; YE; SHEEN, 2012; LAURITO-FRIEND et al., 2015).

O pré-tratamento químico da biomassa diminui a recalcitrância da parede celular à digestão enzimática a partir da desconstrução parcial da matriz lignocelulósica, incluindo o fracionamento de hemiceluloses, celulose e lignina (WYMAN et al., 2005; KUMAR et al., 
2009). Os processos de pré-tratamento podem ser essencialmente divididos em alcalinos ou ácidos. Os processos alcalinos alteram a matriz lignocelulósica devido à degradação da lignina, a solvatação parcial da hemicelulose, e a eventual descristalização da celulose (LAM et al., 2003; GUPTA; LEE, 2010). Os pré-tratamentos ácidos promovem a hidrólise e dissolução das hemiceluloses, praticamente sem remover lignina (HUBBELL; RAGAUSKAS, 2010; CHEN; YE; SHEEN, 2012).

O teor de lignina é um dos parâmetros mais importantes para a recalcitrância da biomassa em diversas espécies vegetais, incluindo gramíneas, como a cana-de-açúcar e o sorgo (GRABBER, 2005; PAULY; KEEGSTRA, 2008; DIEN et al., 2009). A remoção da lignina aumenta a exposição da celulose ao ataque enzimático. Especificamente, a remoção da lignina aumenta a eficiência da hidrólise enzimática devido ao aumento na porosidade da parede celular e a redução da adsorção de enzimas hidrolíticas junto a lignina (YANG et al., 2006; ROLLIN et al., 2011). A recalcitrância enzimática da biomassa e o acesso de enzimas hidrolíticas à celulose também são afetados pela barreira estrutural promovida pelas interações químicas entre as GAX's e o ácido ferúlico e entre as GAX's e a lignina (RANCOUR et al., 2015). As cadeias GAX's se unem aos ácidos ferúlicos por meio de ligações éster entre os resíduos de arabinose e as moléculas de ácido ferúlico (GRABBER, 2005). A associação entre as cadeias GAX's e a lignina ocorre por meio de duas ligações químicas pouco frequentes, a primeira une os resíduos de arabinose junto aos ácidos ferúlicos, e a segunda, une os ácidos ferúlicos a lignina (GRABBER; RALPH; HATFIELD, 1998).

\subsubsection{Recalcitrância da Biomassa Lignocelulósica e Desenvolvimento Vegetativo}

A genômica funcional e a resultante matriz química da biomassa lignocelulósica em função do estágio de desenvolvimento vegetativo do entrenó foi descrita para 2 híbridos de cana-de-açúcar contrastantes para o teor de lignina (BOTTCHER et al. 2013). Este trabalho evidenciou que o teor de lignina aumenta progressivamente até o sexto entrenó contado a partir do ápice. Os entrenós com idade vegetativa mais avançada em comparação ao entrenó 6, apresentam incrementos mínimos no teor de lignina.

As dinâmicas de acúmulo de sacarose e lignocelulose foram descritas simultaneamente em relação ao estágio de desenvolvimento do entrenó (EDE) para 5 cultivares de cana de açúcar (LINGLE; THOMSON, 2012). Em contraste ao trabalho de Bottcher et al., (2013), os dados de Lingle e Thomson (2012), indicam um aumento progressivo e significativo no teor de lignina em relação ao EDE a partir do entrenó 6. Lingle 
e Thomson (2012), demonstraram que o teor de sacarose aumenta progressivamente durante o desenvolvimento vegetativo dos entrenós. No entanto, não detectaram diferenças significativas no teor sacarose a partir do entrenó 9.

Poelking et al. (2015) avaliaram a deposição de lignocelulose nas regiões do córtex e medula ao longo do caule de 2 exemplares do gênero Saccharum. Tanto o exemplar ancestral, Saccharum spontaneum, como o híbrido comercial com aptidão para produção de açúcar e etanol de primeira geração, RB867515, apresentaram similaridades no perfil de deposição de lignina. Especificamente, o aumento progressivo no teor de lignina em relação a idade vegetativa do entrenó caracterizou o aumento da lignificação das paredes das fibras do esclerênquima para os dois genótipos.

Brienzo et al. (2016) também avaliaram a deposição e a distribuição de lignina em entrenós de cana-de-açúcar. No entanto, os autores discutiram essencialmente as diferenças de recalcitrância entre os nós e os entrenós dos caules cultivados durante 6 meses. Especificamente, não existem grandes diferenças de recalcitrância entre o nó e o entrenó não expostos ao pré-tratamento químico. No entanto, os entrenós expostos ao tratamento ácido e alcalino apresentaram menor recalcitrância à hidrolise enzimática em comparação aos nós tratados quimicamente. Os autores sugerem que as diferenças na recalcitrância entre nó e entrenó tratados quimicamente são devido às diferenças no número de aglomerados vasculares e ao teor de lignina entre essas regiões.

\subsubsection{Desconstrução Enzimática da Fração Polissacarídica da Biomassa}

A hidrólise enzimática é um processo efetivo de conversão da biomassa lignocelulósica pré-tratada quimicamente em produtos de maior valor agregado. Esta conversão consiste na hidrólise da celulose e hemicelulose em monômeros (DING et al., 2012; VAN DYK; PLETSCHKE, 2012). A conversão da celulose em monômeros de glicose ocorre devido a ação principal de 3 tipos de enzimas hidrolíticas: endo-(1,4)- $\beta$-glucanases, celobiohidrolases e $\beta$-glucosidases. As enzimas hidrolíticas podem ser auxiliadas por enzimas acessórias como as oxigenases líticas de polissacarídeos (LPMOs) e de swoleninas; tanto as oxigenases com as swoleninas desestruturam os cristais de celulose (KUMAR; MURTHY, 2013; SEGATO et al., 2014).

As hemiceluloses também são degradadas por enzimas hidrolíticas, como as xilanases e enzimas que atuam nos grupos pendentes (SEGATO et al., 2014; MOREIRA; FILHO, 2016). Existem também diversas enzimas que ajudam na desconstrução da hemicelulose 
como: arabinofuranosidases, glucuronosidases, acetil esterases, e feroloil esterases. Betaxilosidades também participam deste processo degradativo das hemiceluloses, pois hidrolisam a xilobiose gerada pela ação da xilanases.

O sucesso da industrialização da conversão da biomassa lignocelulósica, priorizando a utilização da celulose, hemicelulose ou lignina, dependerá de processos químicos e bioquímicos com alta eficiência de desconstrução da matriz lignocelulósica (COSGROVE; JARVIS, 2012; DE MARTINI et al., 2013, SUHARDI et al., 2013). Para a cana-de-açúcar, a industrialização da conversão do bagaço em produtos de alto valor agregado poderia incorporar a produção de açúcar-etanol proveniente da sacarose. O desenvolvimento de híbridos de Saccharum com aptidão dupla: produção de sacarose e acúmulo de biomassa com baixa recalcitrância poderia ser o primeiro passo em direção a industrialização da conversão do bagaço.

\subsection{Análise Multivariada Aplicada a Síntese da Biomassa Lignocelulósica}

A caracterização da composição química e da metabolômica da síntese de polímeros majoritários que compõem a biomassa lignocelulósica comumente descrevem a variável de interesse em função de inúmeras variáveis independentes (YANG et al., 2019). Especificamente, a variável de interesse, como o teor de lignina; ou o teor de ácidos hidroxicinâmicos, ou até mesmo o nível de expressão de genes da família PAL que atuam nas primeiras etapas da sintese de monolignóis que compõem a lignina, é descrita em função de inúmeras variáveis independentes, como o tipo de híbrido ou cultivar, e até mesmo o estágio de desenvolvimento vegetativo (BOTTCHER et al., 2013). Portanto, a caracterização da composição química da biomassa e da metabolômica da síntese da parede celular envolvem cenários complexos que podem ser constituídos por diversas variáveis independentes.

A análise de variância (ANOVA) é uma técnica utilizada quando uma variável é analisada em função de diversos fatores (BRADY et al., 2015). Na ANOVA, a descrição da variável dependente pode incoporar inúmeras relações entre as variáveis independentes. No entato, a utilização desta estratégia, não permite discriminar de maneira simples e clara o efeito que cada variável indepentende apresenta sobre a variável de interesse (BRADY et al., 2015). Em contraste as inúmeras formas de ANOVA, a análise multivariada dos dados por meio da análise de componentes principais (PCA), permite analizar de forma clara e visualizar a correlação entre as variáveis independentes e os efeitos dessas variáveis sobre a varíavel resposta (JOLLIFFE; CADIMA, 2016). 


\subsection{Considerações Finais Sobre a Revisão Bibliográfica}

Os trabalhos e os estudos discutidos anteriormente são essenciais para o entendimento de diversas áreas do conhecimento que estão intrinsicamente ligadas a este estudo. Especificamente, a composição química da biomassa de determinada região ou órgão de uma gramínea sofre grande influência do estágio de desenvolvimento vegetativo e da densidade e heterogeneidade de células. Em adição a esses dois fatores, a composição química da biomassa também pode ser alterada por meio da manipulação da expressão de diversos genes, incluindo genes que sintetizam componentes majoritários da parece celular secundária das células vegetais, como a celulose, a hemicelulose e a lignina. O tratamento químico apesar de custoso possibilita o ato de desembaraçar a biomassa, ou seja, o ato de fracionar a lignocelulose em seus polímeros majoritários para produção de compostos de alto valor agregado. Por fim, existe uma expectativa que o setor sucroalcooleiro possua novas direções além do encargo de produzir: açúcar, etanol e energia elétrica. A integração de estratégias agronômicas, genômicas e bioquímicas certamente possuem a capacidade de reinventar o setor sucroalcooleiro. 


\section{OBJETIVOS}

O objetivo geral desta tese foi avaliar o processo de acúmulo de sacarose e de biomassa lignocelulósica ao longo do processo de desenvolvimento dos entrenós de cana-deaçúcar, correlacionando os dados com a digestibilidade in vitro das amostras analisadas. Em função desta abordagem pretendeu-se identificar genótipos de cana-de-açúcar que possuem elevados rendimentos de sacarose e, simultaneamente, baixa recalcitrância da fração lignocelulósica.

Para atingir este objetivo foram executadas as seguintes etapas:

- Plantio e monitoramento de híbridos experimentais de cana de açúcar até que atingissem a maturidade;

- Amostragem de 4 diferentes híbridos de cana de açúcar no sentido de recolher entrenós que representassem estágios progressivos de desenvolvimento;

- Avaliação micrscópica dos entrenós a fim de avaliar a formação dos tecidos e o acúmulo de biomassa;

- Determinação dos teores de sacarose, de biomassa lingocelulósica e da composição dos componentes da biomassa lignocelulósica;

- Determinação da digestibilidade in vitro das frações lignocelulósicas;

- Avaliação de correlações entre os diferentes estágios de desenvolvimento, a composição química da fração lignocelulósica e a digestibilidade in vitro. 


\section{Capítulo 2}

4 ARTIGO CIÊNTIFICO I "Sucrose content, lignocellulose accumulation and in vitro digestibility of sugarcane internodes depicted in relation to internode maturation stage and Saccharum genotypes"

Este capítulo corresponde à versão em português do artigo originalmente intitulado "Sucrose content, lignocellulose accumulation and in vitro digestibility of sugarcane internodes depicted in relation to internode maturation stage and Saccharum genotypes" de autoria de Daniel Collucci, Raphael CA Bueno, Adriane MF Milagres, André Ferraz. O artigo foi publicado no periódico Industrial Crops \& Products 139 (2019) 111543.

\section{Resumo}

Híbridos comerciais de Saccharum adquiriram várias características por meio do melhoramento genético, incluindo, elevada produção de sacarose e lignocelulose. Recentemente, o setor sucroalcooleiro e as biorefinarias projetadas para a produção de combustíveis e compostos químicos de alto valor agregado a partir da biomassa incentivaram novos esforços para o desenvolvimento de genótipos de cana-de-açúcar com alto teor de sacarose e baixa recalcitrância de lignocelulose. O presente estudo utilizou 4 híbridos experimentais de cana-de-açúcar desenvolvidos dentro do contexto das novas perspectivas de utilização da biomassa do bagaço de cana para avaliar as dinâmicas de acúmulo de sacarose e lignocelulose, composição química da lignocelulose e a digestibilidade da biomassa dos entrenós. Durante os estágios de maturação dos entrenós, o teor de sacarose aumentou enquanto a fração lignocelulósica apresentou aumento de lignina e redução no teor de glucanas. A digestibilidade enzimática e o teor de lignina exibiram um padrão inversamente relacionado, especificamente, a digestibilidade do primeiro entrenó foi duas vezes maior em comparação aos entrenós maduros, indicando que a digestibilidade diminui significativamente devido a maturação dos entrenós e a lignificação dos tecidos. Os híbridos de cana-de-açúcar H89 e H58, combinaram características fenotípicas desejáveis da cana de açúcar (alto teor de sacarose e baixa recalcitrância da biomassa) não detectadas nos híbridos H140 e H321. Marcadores moleculares específicos para discriminar essas características poderiam auxiliar no desenvolvimento de genótipos de cana-de-açúcar com aptidão dupla, ou seja, alto rendimento de sacarose e baixa recalcitrância de lignocelulose 


\section{Introdução}

O sucesso da industrialização da conversão da biomassa em polímeros majoritários como a celulose, hemiceluloses e lignina, depende de pré-tratamentos químicos economicamente viáveis e da conversão eficiente desses polímeros majoritários em combustíveis e produtos químicos de alto valor agregado (GUO; SONG, 2019; HOLVERDA et al., 2019). A maior parte da biomassa vegetal disponível para o bioprocessamento está contida nas paredes celulares secundárias das plantas vasculares (YANG et al., 2013). Estas paredes celulares são recalcitrantes à biodegradação ou à digestão enzimática in vitro devido a ultraestrutura química complexa (HIMMEL et al., 2007; DING et al., 2013). Diversos estudos revelaram que a solubilização de polissacarídeos in vitro requer inúmeras etapas, incluindo o prétratamento químico e a digestão enzimática (PETRIDIS; SMITH, 2018; HOLVERDA et al., 2019). A desconstrução das paredes celulares das plantas é facilitada quando os teores de lignina e xilana são baixos (JUNG, 2012; COSTA et al., 2013; DING et al., 2013; SANTOS et al., 2018), enquanto altos teores de celulose e glucanas de ligação mista (ß-1, 4 e $\beta-1)$, e baixa cristalinidade da celulose aumentam a digestibilidade (VEGA-SANCHEZ et al., 2013; COSTA et al., 2016).

Em gramíneas, a recalcitrância da parede celular aumenta durante o desenvolvimento vegetativo da planta e devido a maturação dos tecidos. Essencialmente, a recalcitrância da parede celular aumenta devido ao processo de lignificação (JUNG; CASLER, 2006; CROWE et al., 2017). Durante o desenvolvimento vegetativo, algumas gramíneas, como a cana-deaçúcar e o sorgo, acumulam carboidratos estruturais e não-estruturais (especialmente a sacarose) em altas concentrações (LINGLE; THOMSON, 2012; MCKINLEY et al., 2018). O acúmulo desses carboidratos nessas plantas é uma característica desejada para a produção de combustíveis de primeira e segunda geração (MENDES et al., 2017; MULLET, 2018). No entanto, o acúmulo de sacarose e a lignificação das paredes celulares secundárias são processos que ocorrem simultaneamente. O acúmulo de sacarose ocorre nas células do parênquima, enquanto que a maior parte da lignina acumula-se nas paredes celulares secundárias das fibras do esclerênquima e dos vasos xilemáticos. Ambos os processos ocorrem durante a maturação dos entrenós (LINGLE; THOMSON, 2012; LI et al., 2018). Por exemplo, genes associados à síntese de lignina são altamente expressos durante a maturação, especialmente, em híbridos de cana-de-açúcar com alto teor de fibras (BOTTCHER et al., 2013; KASIRAJAN et al., 2018). 
A cana-de-açúcar serve como uma planta-modelo para a avaliação do acúmulo de sacarose simultaneamente à evolução da recalcitrância das paredes celulares secundárias. Híbridos experimentais de cana-de-açúcar desenvolvidos pela Rede Interuniversitária para o Desenvolvimento do Setor Sucroenergético (RIDESA) possuem características contrastantes na composição química da biomassa do bagaço que oferecem uma janela de oportunidades para caracterizar a avaliação da recalcitrância junto ao processo de acúmulo de sacarose (WACLAWOVSKY et al., 2010; LOUREIRO et al., 2011; MASARIN et al., 2011; SILVA, 2017). A maioria dos híbridos comerciais de cana-de-açúcar apresentam alto acúmulo de sacarose, alta produtividade de campo, resistência a pragas e a períodos de estiagem (LAKSHMANAN et al., 2005; WACLAWOVSKY et al., 2010; LOUREIRO et al., 2011; TAVARES et al., 2018). Esforços recentes resultaram no desenvolvimento de híbridos de cana-de-açúcar com características orientadas para atender à tradicional e as novas necessidades do sector sucroalcooleiro, como a conversão da lignocelulose do bagaço da cana-de-açúcar em produtos químicos e etanol celulósico (MASARIN et al., 2011; LAURITO et al., 2015; SILVA et al., 2017; MENDES et al., 2018). No entanto, até o presente momento (final da década de 2010) não existem genótipos comerciais de cana com aptidão para a produção de sacarose e acúmulo simultâneo de biomassa com baixa recalcitrância.

Um dos primeiros estudos associando os estágios de desenvolvimento vegetativo da cana com a digestibilidade in vitro da fração lignocelulósica comparou espécies ancestrais de cana-de-açúcar (Saccharum spontaneum) com híbridos comerciais desenvolvidos para o acúmulo de elevadas concentrações de sacarose (POELKING et al., 2015). Amostras do bagaço desses 2 híbridos foram pré-tratadas com ácido diluído e digeridas com enzimas hidrolíticas. A digestibilidade máxima foi encontrada nos entrenós intermediários. Esses resultados são contrastantes em comparação aos resultados reportados para outras gramíneas C4 como o milho e espécies do gênero Panicum. Especificamente, amostras não pré-tratadas quimicamente de milho (JUNG; CASLER, 2006) e amostras pré-tratadas quimicamente com ácido diluído de Panicum maximum (CROWE et al., 2017) apresentaram alta digestibilidade nos entrenós mais jovens.

O presente trabalho considerou a hipótese de que híbridos de cana-de-açúcar poderiam atingir altos teores de acúmulo de sacarose antes das paredes celulares secundárias se tornarem completamente desenvolvidas e lignificadas. A existência dessas características abriria novas perspectivas para o melhoramento de plantas visando alta produção de sacarose e lignocelulose com baixa recalcitrância. O caule da cana é composto por entrenós em estágios de maturação sucessivos e contrastantes em relação a composição química da 
biomassa. Este estudo caracterizou o acúmulo de sacarose, a composição química de lignocelulose e a digestibilidade enzimática da fração lignocelulósica ao longo do caule de 4 híbridos experimentais de cana-de-açúcar. Os dados deste estudo indicaram que ao longo da maturação dos entrenós, os teores de sacarose aumentaram, enquanto a fração de lignocelulose apresentou aumento de lignina e diminuição do conteúdo de glucanas. A digestibilidade enzimática e o teor de lignina exibiram padrões inversamente relacionados. Dentre os híbridos avaliados, alguns exemplares combinaram as características desejáveis a utilização da biomassa para a produção de biocombustíveis e compostos de alto valor agregado como o alto teor de sacarose e a baixa recalcitrância da lignocelulose à hidrólise enzimática.

\section{Materiais e Métodos}

\section{Híbridos de cana-de-açúcar e amostragem da biomassa}

Híbridos experimentais de cana-de-açúcar $(\mathrm{n}=4)$ foram amostrados do campo experimental do Departamento de Biotecnologia da Universidade de São Paulo, Escola de

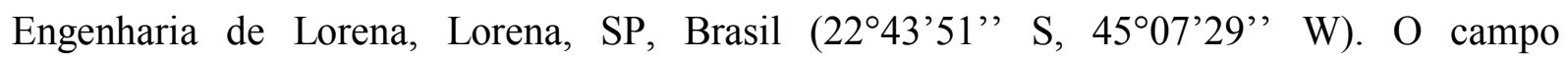
experimental continha um total de 15 genótipos diferentes, plantados em linhas de $0,6 \mathrm{~m} \times 1 \mathrm{~m}$ com espaçamento de $3 \mathrm{~m}$ x $2 \mathrm{~m}$ entre os híbridos. As amostras deste estudo correspondem aos caules cana soca de 1 ano de idade coletados em maio de 2016. Especificamente, dois dos 15 genótipos foram selecionados com base em seus baixos teores de lignina (H89 e H58), contrastando com o genótipo H140, que apresentava o maior conteúdo de lignina entre os genótipos. O genótipo H321 foi selecionado devido ao maior teor de hemiceluloses em comparação aos demais híbridos (MASARIN et al., 2011).

As amostras $(n=3)$ selecionadas de cada genótipo apresentavam caules de altura e diâmetro semelhantes. Após o corte no campo, as folhas foram removidas para a identificação dos entrenós jovens que se encontram protegidos pelas folhas do ápice do caule. O primeiro entrenó, identificado como I1 correspondeu ao primeiro entrenó, a partir do qual, nós superiores e inferiores a I1 podiam ser claramente identificados (Figura 2.1). Cada entrenó desde o ápice até a base do caule foram amostrados. O número total de entrenós amostrados foram 13, 15, 19 e 19 para H89, H58, H321 e H140, respectivamente. No entanto, alguns caules apresentaram até 24 entrenós. Após amostragem, duas secções de $6 \mathrm{~mm}$ de comprimento foram cortadas da região média do entrenó e separadas para análise 
microscópica. O material remanescente foi usado para a determinação dos teores de sacarose e biomassa lignocelulósica, composição química e digestibilidade enzimática. Todas as amostras foram armazenadas em sacos plásticos a $-18^{\circ} \mathrm{C}$ até serem utilizadas.

Figura 2.1 Identificação do primeiro nó completamente definido após a remoção das folhas do ápice do caule. O primeiro entrenó correspondeu a região em que os nós superiores e inferiores foram claramente identificados.

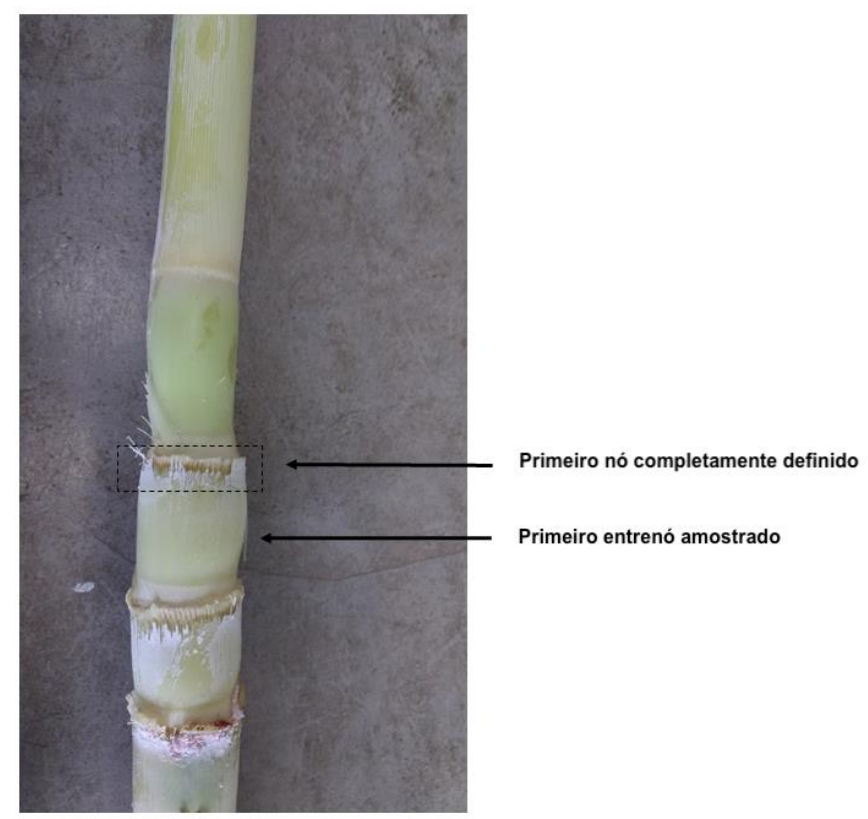

Fonte: Arquivo pessoal.

\section{Determinação dos teores de sacarose e fibras}

Os entrenós foram descongelados à temperatura ambiente e pesados (cana in natura) após a remoção do excesso de umidade condensada na superfície. As amostras foram trituradas em um liquidificador com $400 \mathrm{~mL}$ de $\mathrm{H}_{2} \mathrm{O}$ durante $5 \mathrm{~min}$. Os sólidos foram retidos em um filtro de malha de nylon de 200 mesh, e a fração líquida foi reservada para determinação de sacarose. O procedimento de remoção de sacarose dos entrenós foi repetido 3 vezes e as frações líquidas foram combinadas. A sacarose foi determinada na fração líquida combinada utilizando um HPLC acoplado a uma coluna HPX87C (BioRad, Hercules, CA) mantida a $85^{\circ} \mathrm{C}$ e eluída a $0,6 \mathrm{~mL} / \mathrm{min}$ com água destilada.

A biomassa lignocelulósica (fibras) correspondeu ao total de sólidos retidos após a extração da sacarose. A biomassa lignocelulósica foi seca a temperatura ambiente previamente a pesagem. Subamostras da biomassa foram utilizadas para a determinação de 
umidade utilizando um determinador de umidade Shimadzu MOC-120H (Shimadzu, Japão). O peso seco foi calculado e a biomassa lignocelulósica foi expressa como g de sólidos secos / $100 \mathrm{~g}$ de cana fresca. A biomassa lignocelulósica seca ao ar foi moída em um moinho tipo Wiley acoplado a uma malha de 0,84 mm. As amostras moídas foram utilizadas para a determinação da composição química e a digestibilidade in vitro. Os extrativos e os componentes majoritários da parede celular foram determinados segundo Masarin et al., (2011).

\section{Digestibilidade enzimática in vitro da lignocelulose}

A biomassa lignocelulósica foi digerida com um coquetel enzimático celulolítico (Cellic Ctec2 - SAE0020, Sigma-Aldrich, Brasil). Aproximadamente $20 \mathrm{mg}$ de biomassa foram depositadas no interior de tubos criogênicos de $2 \mathrm{~mL}$ contendo $900 \mu \mathrm{l}$ de uma solução tampão de acetato $50 \mathrm{mM}+0,01 \%$ de azida sódica. Após aproximadamente 12 horas de impregnação, $100 \mu \mathrm{L}$ do coquetel enzimático celulolítico diluído foi adicionado. A razão entre enzimas e biomassa correspondeu a $10 \mathrm{FPU} / \mathrm{g}$ de substrato. Os frascos foram incubados a temperatura de $45^{\circ} \mathrm{C}$ sob agitação de $120 \mathrm{rpm}$ por até $72 \mathrm{~h}$. As amostras retiradas dos tubos criogênicos foram diluídas e analisadas para determinação do conteúdo de glicose e xilose por HPLC utilizando uma coluna HPX-87H (BioRad, Hercules, CA) mantida a $45{ }^{\circ} \mathrm{C}$ e eluída com 0,6 $\mathrm{mL} / \mathrm{min}$ de solução de $\mathrm{H}_{2} \mathrm{SO}_{4} 5 \mathrm{mM}$. Os açúcares foram detectados em um detector de RI termocontrolado a $35^{\circ} \mathrm{C}$ (Waters, Milford, MA) (MASARIN et al., 2011).

\section{Dimensionamento celular microscópico}

Fragmentos longitudinais de aproximadamente $6 \mathrm{~mm}$ de comprimento e $1 \mathrm{~mm}$ de diâmetro foram seccionados de cada entrenó com uma lâmina de barbear. Os fragmentos foram amostrados a uma distância de $8 \mathrm{~mm}$ da região mais externa do entrenó em direção a medula (COSTA et al., 2013). Cada fragmento foi fixado em resina epóxi e cortado transversalmente em fatias de $1 \mu \mathrm{m}$ de espessura com auxílio de um ultramicrótomo LEICA EM-UC7 (Leica Biosystems, Alemanha) equipado com uma faca de diamante (4mm-Histo, Diatome, Hatfield, PA), conforme descrito por Costa et al., (2013). As fatias foram observadas em um microscópio OLYMPUS BX53 (Olympus, Japão). As dimensões celulares foram anotadas com o auxílio do software CellSens (Olympus, Japão). As áreas das células do parênquima e dos aglomerados vasculares foram determinadas como ilustrado na Figura 2.2. 
A espessura das paredes das células das fibras foi medida usando o software CellSens. Pelo menos 20 células de parênquima e fibras foram avaliadas em cada amostra e utilizadas para calcular os valores médios. No caso dos aglomerados vasculares, apenas 2 ou 3 feixes foram visualizados em cada amostra e usados para determinar valores médios para cada híbridoentrenó.

Figura 2.2. Imagem microscópica típica da região do córtex do entrenó da cana ilustrando as áreas de uma célula do parênquima e do aglomerado vascular

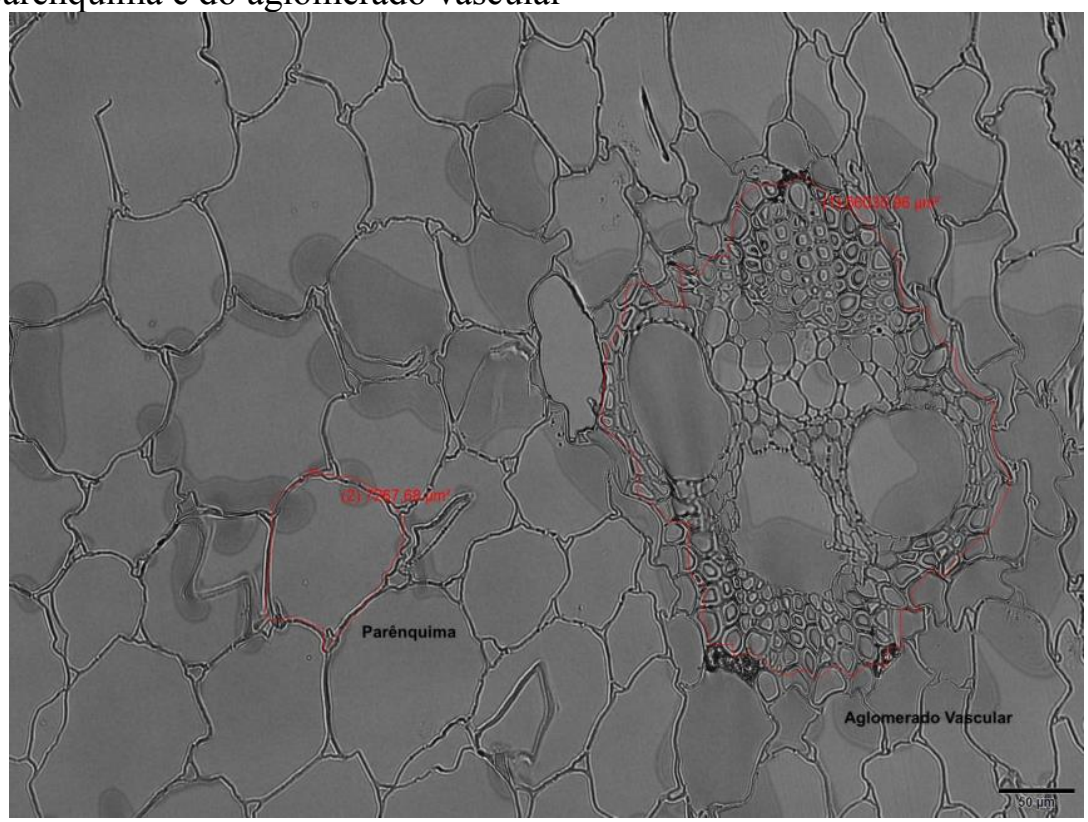

Fonte: Arquivo pessoal

\section{Análise Estatística}

Os dados para os teores de sacarose e fibras, dimensões microscópicas celulares, composição química da biomassa e digestibilidade in vitro foram avaliados $(n=3)$ para os 4 genótipos de cana-de-açúcar. Os dados analíticos foram obtidos a partir de análises em triplicatas. Cada conjunto de dados passaram por um teste de distribuição normal e os desvios padrão foram determinados. As médias estatísticas foram comparadas no seguinte conjunto de dados: 4 genótipos, 3 caules de cada genótipo, e 3 (I1, I5, I11) ou 4 (I1, I3, I5, I11) entrenós. Os dados foram analisados por testes de Tukey, utilizando-se $\mathrm{P}<0,1$ (HYNES et al., 2013). 


\section{Resultados}

\section{Acúmulo de sacarose e lignocelulose em função do estágio de maturação do entrenó}

O acúmulo de sacarose e biomassa, a anatomia das células parenquimáticas e dos aglomerados vasculares, a composição química da parede celular e a digestibilidade in vitro dos 4 híbridos de cana-de-açúcar foram avaliados em função dos estágios de maturação dos entrenós. Os entrenós foram amostrados progressivamente do ápice em direção a base do caule, sendo que esta sistemática permitiu a representação dos diferentes estágios de desenvolvimento vegetativo dos entrenós (LING; THONSON, 2012; BOTTCHER et al., 2013; POELKING et al., 2015).

As características avaliadas para cada híbrido estão resumidas na Tabela S1. Em geral, os exemplares de cana-de-açúcar apresentaram alturas de caule variando entre 1,9 a 2,5m, contendo 18 a 24 entrenós. Os entrenós jovens coletados no ápice do caule, como o entrenó I1, apresentaram comprimento $(4,2-7,6 \mathrm{~cm})$ e peso (19-33g cana in natura), inferiores aos entrenós maduros coletados na região mediana-basal do caule da cana (entrenó I11). O entrenó I11 apresentou comprimento entre $10,4-13,3 \mathrm{~cm}$ e peso ao redor de $72-80 \mathrm{~g}$ de cana in natura. Os híbridos H89, H58, H321 e H140 apresentaram diâmetros médios dos entrenós de 2,4, 2,6, 3,3 e 2,8cm, respectivamente.

O padrão de acúmulo de sacarose nos entrenós foi similar para todos os híbridos. Essencialmente, o teor de sacarose aumentou rapidamente do entrenó I1 para I5, com incrementos menores até o I1 1 (Figura S1 e Figura 2.3). Quando disponíveis, os entrenós I13 também foram avaliados quanto à sacarose e teores de biomassa lignocelulósica; no entanto, os valores médios não diferiram significativamente do entrenó I11, sugerindo que todos os entrenós a partir do I11, podem ser caracterizados como entrenós maduros, ou seja, representam a região madura do caule. $\mathrm{O}$ teor de sacarose detectado no entrenó $\mathrm{I} 11$ nos diferentes híbridos apresentou baixa variabilidade (16,1\% em H89 a 18,7\% em H58) e seguiu o mesmo padrão anteriormente relatado para o conjunto de todos os entrenós existentes nos caules desses híbridos (MASARIN et al., 2011).

Em contraste com o acúmulo de sacarose, o conteúdo de biomassa lignocelulósica aumentou ao longo dos entrenós I1 a I11. Os genótipos H140 e H321 exibiram o maior e o menor conteúdo de fibra, respectivamente (Figura S1). A figura 2.3, ilustra os valores médios de sacarose e da biomassa lignocelulósica agrupados independente do híbrido; as linhas pontilhadas indicam valores máximos e mínimos identificados no conjunto de dados. $\mathrm{O}$ 
padrão de acúmulo de sacarose e biomassa lignocelulósica nos híbridos sugerem que o acúmulo de sacarose nas células do parênquima precede o desenvolvimento completo das paredes celulares secundárias nos feixes vasculares.

Figura 2.3. Teores de sacarose (círculos azuis) e biomassa lignocelulósica (triângulos vermelhos) em relação à posição do entrenó no caule da cana. Os teores representam médias agrupadas dos híbridos H89, H58, H321 e H140 para cada entrenó. As linhas pontilhadas indicam os valores máximos e mínimos detectados nos híbridos em estudo. Dados independentes de cada um dos híbridos avaliados podem ser visualizados na Figura S1

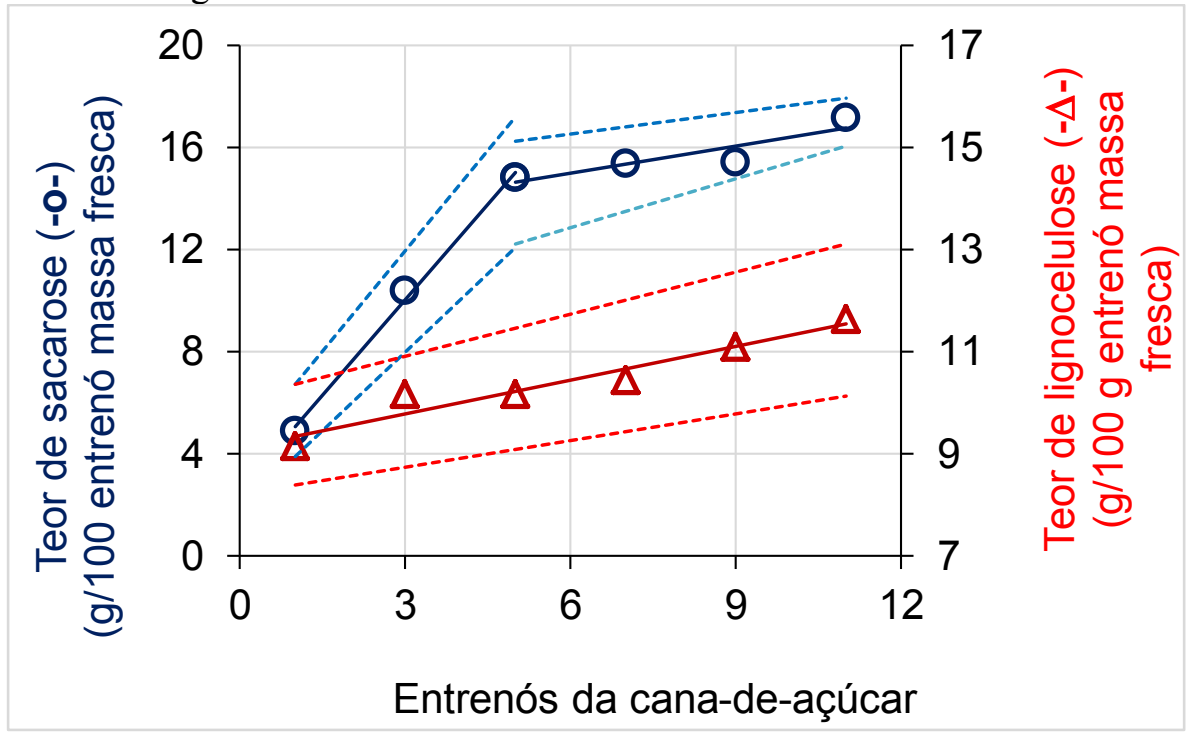

Fonte: Arquivo pessoal

A avaliação microscópica da região do córtex dos entrenós foi utilizada para determinar as áreas médias das células do parênquima e dos feixes vasculares, e para estimar a espessura das paredes celulares secundárias das células das fibras (Figura 2.4). A área das células do parênquima aumentou significativamente de I1 para I11 nos híbridos H58 e H321. Em contraste, não houve alteração significativa na área dos aglomerados vasculares ao longo dos estágios de maturação dos entrenós. A espessura da parede das células das fibras aumentaram do entrenó I1 para I11. Esses resultados colaboram com o acúmulo progressivo de lignocelulose durante o desenvolvimento vegetativo do entrenó. A maior parte do peso seco da biomassa lignocelulósica observada nos entrenós de cana-de-açúcar são atribuídos às paredes das células da fibra presentes nos feixes vasculares. As células parenquimáticas, apesar de grandes e numerosas, apresentam paredes celulares finas, e portanto, representam uma pequena porção do peso seco da biomassa total (MOORE, 1987; BRIENZO et al., 2016). 
Figura 2.4 Dimensões celulares e teciduais da região do córtex de 3 entrenós em estágios diferentes de maturação de 4 híbridos de cana-de-açúcar. Amostras com as mesmas letras não diferem entre si pelo teste de Tukey com um nível de significância $P<0,1$

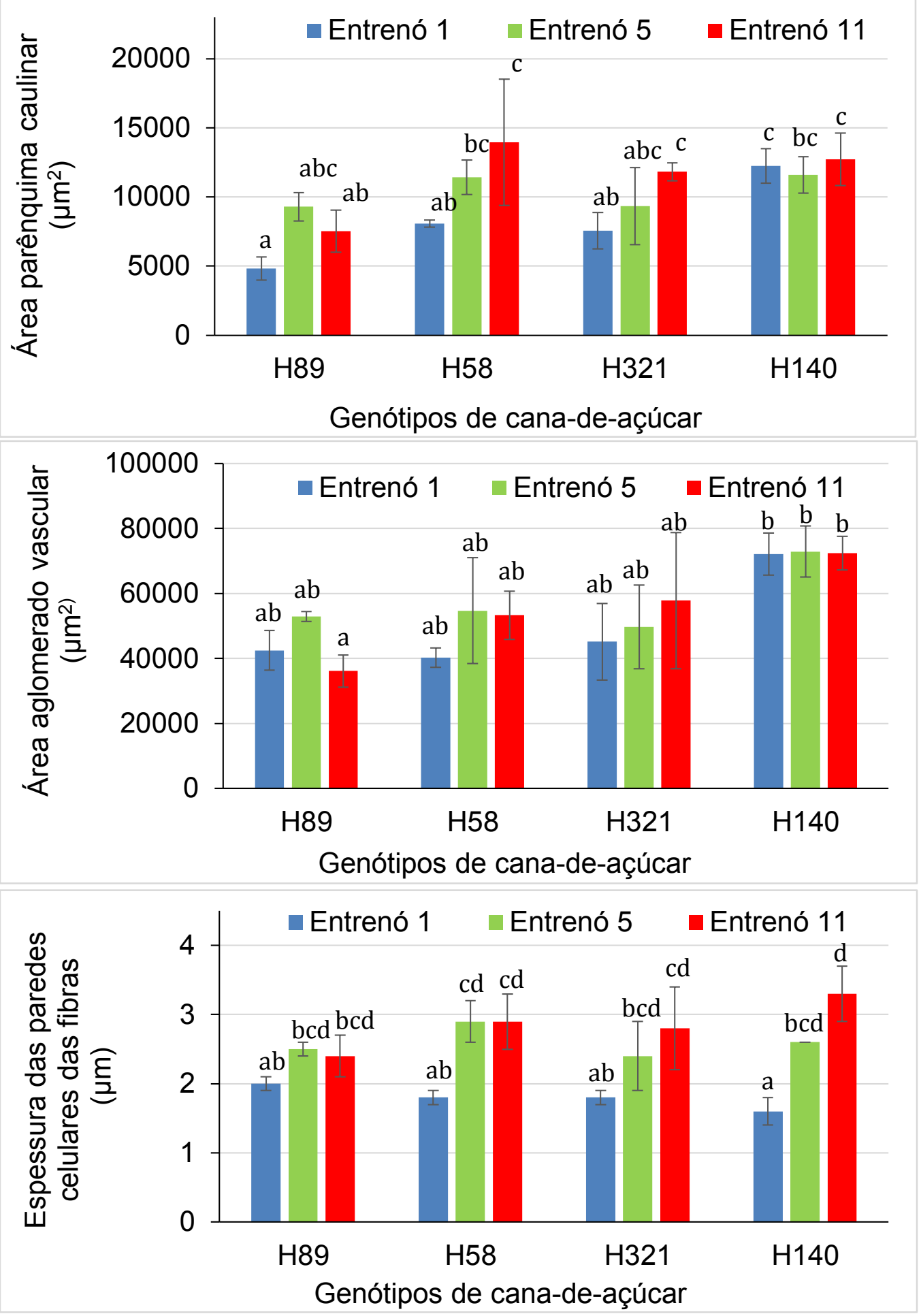

Fonte: Arquivo pessoal 


\section{Composição química da lignocelulose}

Os dados relativos aos principais constituintes da parede celular de cada híbrido estão disponíveis na Figura 2.5, e os modelos de regressão descrevendo a relação entre a composição química da biomassa em relação ao estágio de desenvolvimento vegetativo do entrenó, estão disponíveis no material suplementar Figura S2. Em geral, os híbridos exibiram padrões contrastantes de acúmulo de lignina e polissacáridos estruturais. Os híbridos H89 e H58, apresentaram baixo teor de lignina total, no entanto, alta taxa de acúmulo de lignina do entrenó I1 para o I5. Nestes híbridos, a lignina acumulou na proporção de 1,5\% por entrenó; os teores iniciais estavam próximos a 11,9-12,3\% no entrenó I1 e em torno de 19,6-20,5\% no entrenó I5. Em contraste, o teor de lignina nos híbridos H321 e H140 aumentaram de forma constante; a taxa de acúmulo de lignina desses híbridos foi baixa, em torno de $0,5-0,6 \%$ por entrenó. No entanto, esses híbridos apresentaram teores iniciais de lignina altos, em torno de 15,8-16,6\%; atingindo até mesmo valores máximos no entrenó I11 em torno de 20,9-23,5\%.

O teor de glucanas e xilanas apresentou um comportamento inverso à deposição de lignina. Especificamente, os teores de polissacarídeos estruturais diminuíram ao longo do desenvolvimento vegetativo e durante a maturação dos entrenós (Figura 2.5). A diminuição na proporção de polissacarídeos estruturais na biomassa lignocelulósica, indica que as paredes celulares tornam-se lignificadas ao longo dos diferentes estágios de desenvolvimento vegetativo, ou seja, existe uma aumento na densidade e na espessura da parede celular devido a deposição de lignina. O efeito global da transição de tecidos jovens até os tecidos maduros nos entrenós da cana-de-açúcar é essencialmente a diminuição da proporção de polissacarídeos em relação à lignina. A comparação de entrenós contrastantes para este gradiente de teores de polissacarídeos e lignina, demonstra que o entrenó I1 contém uma menor quantidade de tecidos lignificados, enquanto I1 1 representa um entrenó completamente maduro, ou seja, completamente lignificado. 
Figura 2.5. Composição química da biomassa lignocelulósica de 4 entrenós em estágios diferentes de maturação de 4 híbridos de cana-de-açúcar. Amostras com as mesmas letras não diferem entre si pelo teste de Tukey com um nível de significância $P<0,1$
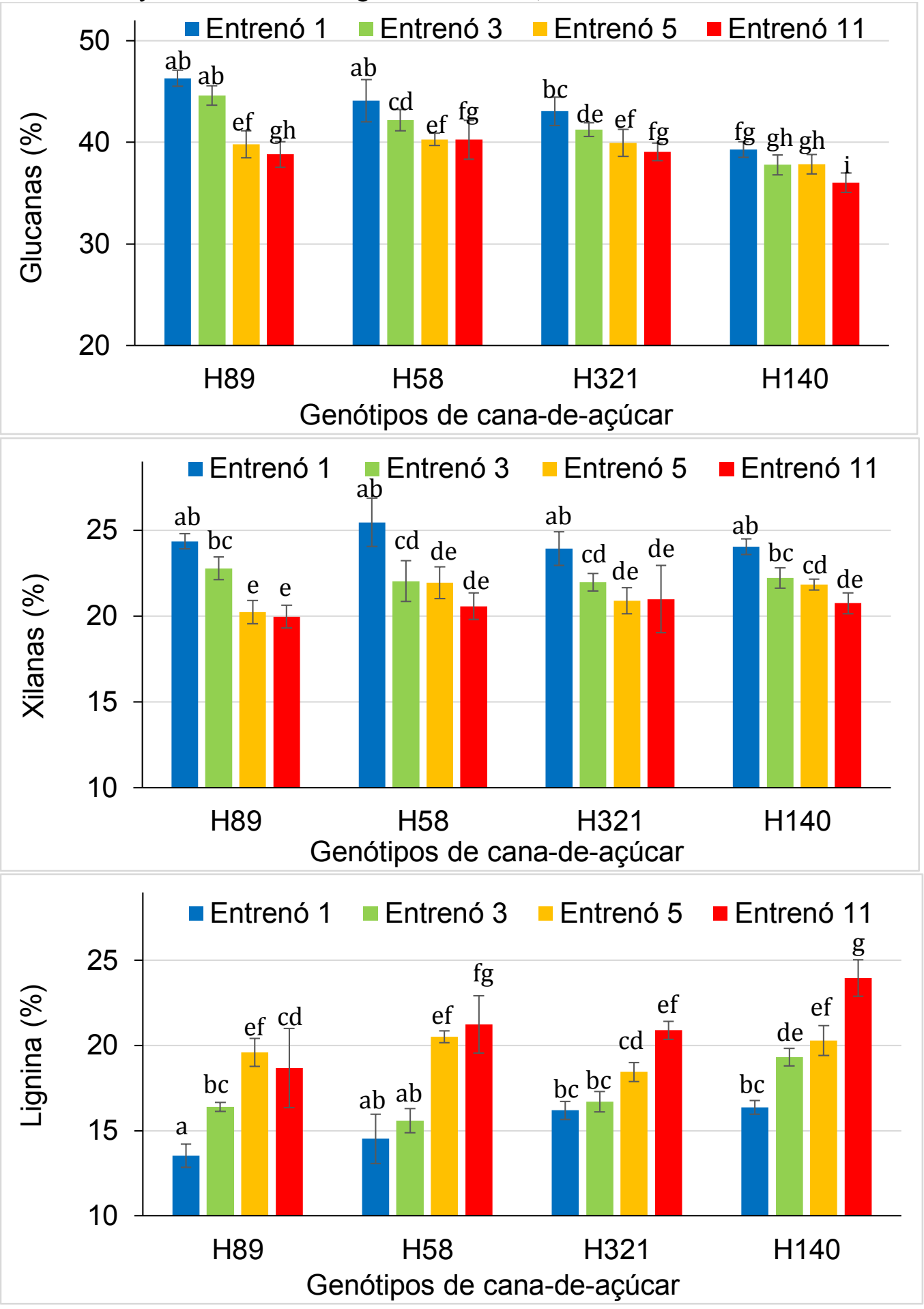

Fonte: Arquivo pessoal 


\section{Hidrólise Enzimática}

A digestão enzimática in vitro das amostras (Figura S3) foi avaliada em intervalos de tempo $(4,8,24,48$ e $72 \mathrm{~h})$ para estimar as taxas iniciais de hidrólise, bem como a conversão de glucanas e xilanas após um período de tempo de $72 \mathrm{~h}$ (Figura 2.6). As taxas iniciais de hidrólise de glucanas no I1 variaram entre $4,7 \pm 0,4 \% \cdot \mathrm{h}^{-1}$ para $\mathrm{H} 140$ a $7,6 \pm 0,4 \% \cdot \mathrm{h}^{-1}$ para H89. Para esses híbridos, as taxas inicias de hidrólise de glucanas observadas para I1 e I11 foram $3,5 \pm 0,1 \% \cdot \mathrm{h}^{-1}$ e $6,1 \pm 0,5 \% \cdot \mathrm{h}^{-1}$, respectivamente. A cinética de hidrólise de xilanas apresentou um comportamento similar a cinética de hidrólise de glucanas (Figura S3).

As conversões de glucanas e xilanas após $72 \mathrm{~h}$ de hidrólise enzimática (Figura 2.6) indicaram que a maior digestibilidade de glucanas foi observada nos entrenós jovens e diminuíram até I11(Figura 2.6A). Diferenças relevantes nas conversões de glucanas e xilanas foram detectadas entre os híbridos. Por exemplo, o I1 do H140 apresentou digestibilidade similar ao I11 do H89. Os entrenós I1 dos híbridos com baixa recalcitrância da biomassa a hidrólise enzimática, ou seja, os híbridos H89 e H58, alcançaram conversões de glucanas próximos a 45\% sem qualquer pré-tratamento químico da fração lignocelulósica. Os níveis de conversão de xilanas foram ligeiramente inferiores aos de glucanas; no entanto, apresentaram um padrão similar ao observado para a conversão de glucanas (Figura 2.6B). 
Figura 2.6. Conversão de glucanas (A) e xilanas (B) após hidrólise enzimática in vitro de 4 entrenós em estágios diferentes de maturação de 4 híbridos de cana-de-açúcar. Amostras com as mesmas letras não diferem entre si pelo teste de Tukey com um nível de significância $P<0,1$
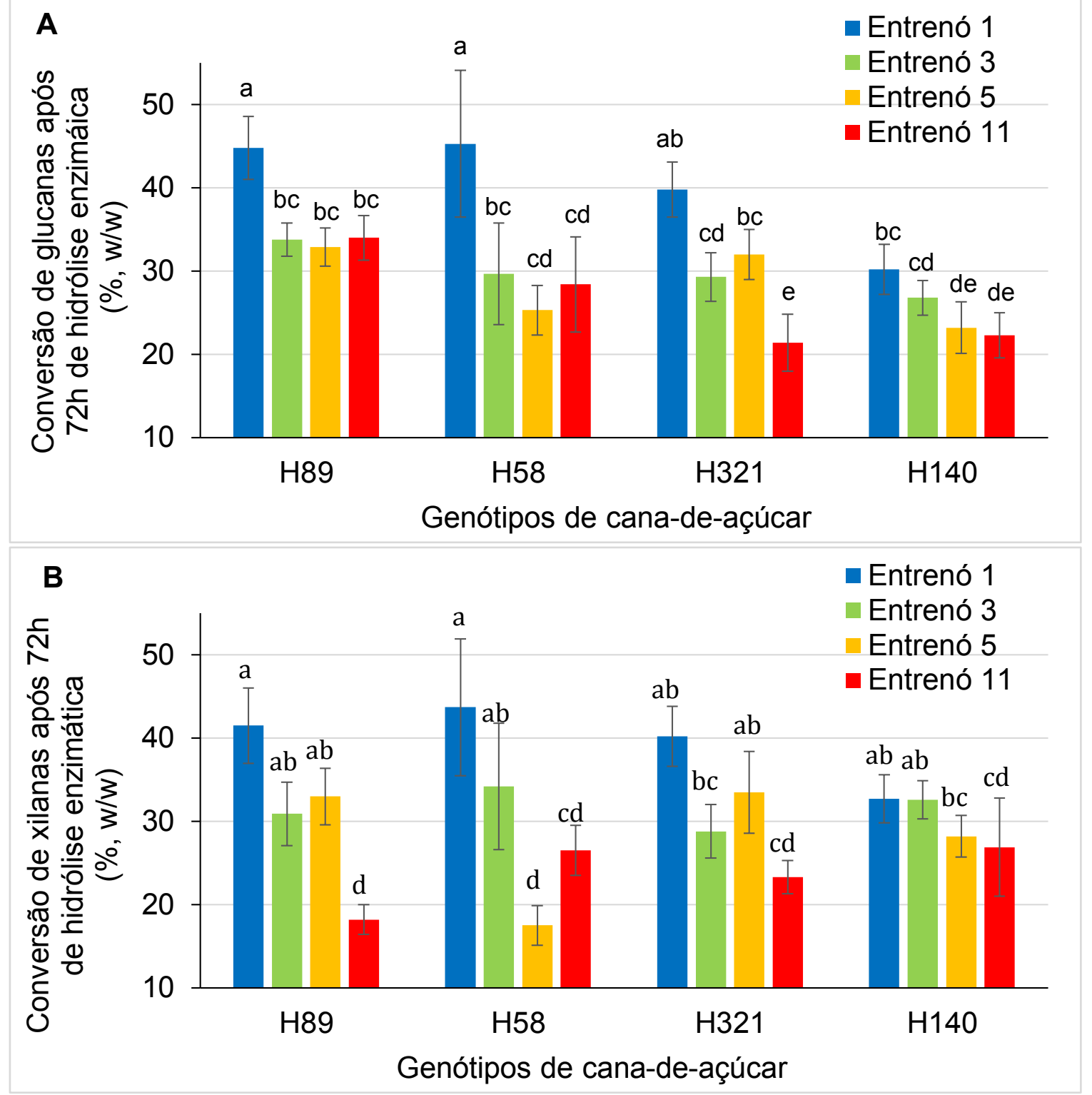

Fonte: Arquivo pessoal

Os níveis de digestibilidade de glucanas dos entrenós refletem os teores de lignina e de glucanas. Um modelo de regressão linear simples foi desenvolvido para descrever a digestibilidade de glucanas dos entrenós em função da composição química. O modelo considera a ultra-estrutura amplamente aceita das paredes celulares secundárias onde a hemicelulose e a lignina encapsulam as microfibrilas de celulose, dificultando o acesso de enzimas as cadeias de celulose (LOQUE; SCHELLER; PAULY, 2015; PETRIDIS; SMITH, 2018). A Figura 2.7A correlaciona a digestibilidade de glucanas em relação ao conteúdo de glucanas dividido pela soma dos teores de lignina e xilanas detectada em cada entrenó. 
Correlações positivas podem ser observadas neste gráfico, sugerindo que a digestibilidade pode ser facilmente estimada com base na composição química das amostras. O mesmo modelo estatístico foi utilizado para predizer a digestibilidade de glucanas em um conjunto de dados externo aos dados coletados neste estudo, incluindo amostras compostas da casca, córtex e medula de entrenós maduros de 6 híbridos de cana-de-açúcar (COSTA et al., 2016). As predições foram robustas e ampliaram a capacidade do modelo em generalizar as predições para novos dados (Figura 2.7B). Ambas as predições indicaram que a digestibilidade de glucanas aumenta a medida que o teor de glucanas aumenta e o teor dos componentes encapsuladores de glucanas, como a lignina e as xilanas diminuem.

Figura 2.7. Modelos de regressões lineares simples e coeficientes de correlação que explicam os níveis de conversão de glucanas em função do conteúdo de glucanas dividido pela soma de lignina e xilana (A)

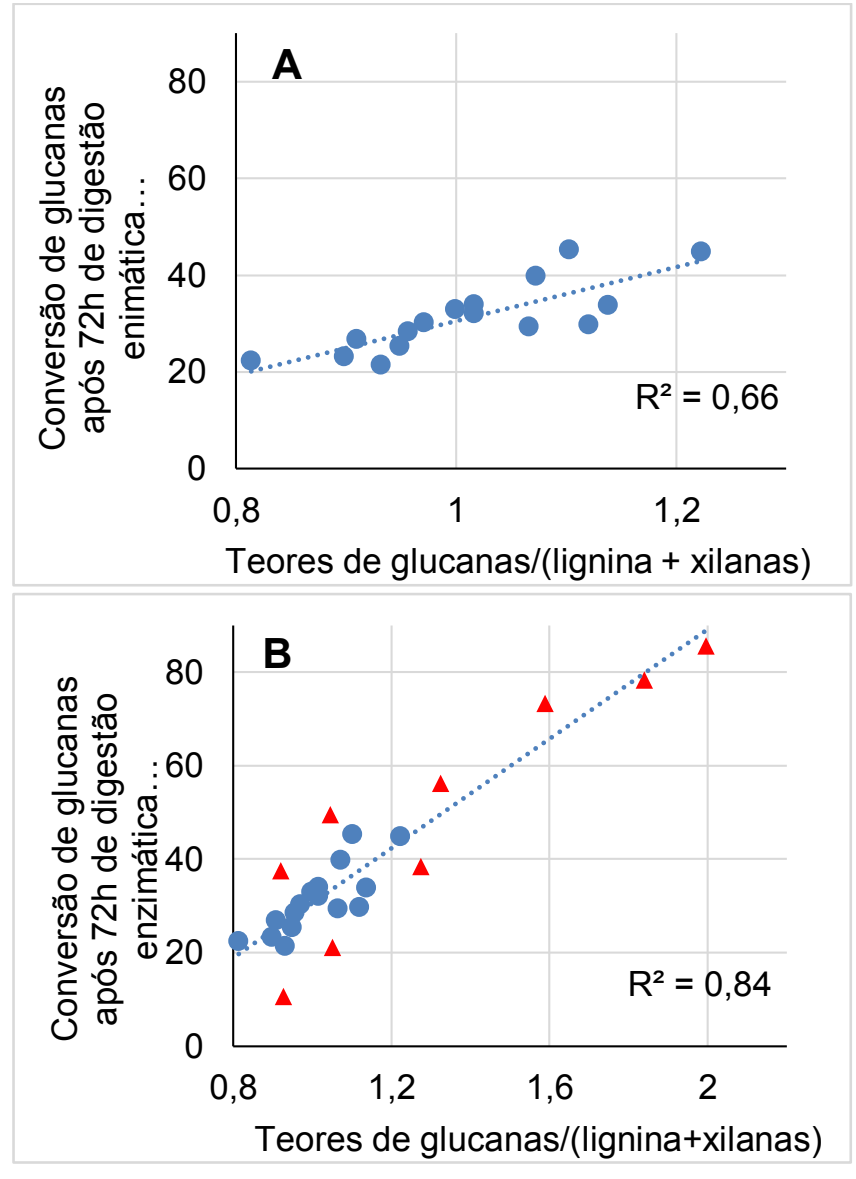

Fonte: Arquivo pessoal

Dados obtidos no trabalho atual (círculos azuis) sobrepostos com dados de Costa et al. (2016) (triângulos vermelhos) (B) 


\section{Discussão}

A digestibilidade de glucanas e xilanas diminuiu significativamente devido a maturação dos entrenós. Estes resultados estão em sintonia com estudos conduzidos com outras gramíneas $\mathrm{C} 4$, como por exemplo, amostras não pré-tratadas quimicamente de milho (JUNG; CASLER, 2006) e amostras pré-tratadas quimicamente com ácido diluído de espécies do gênero Panicum (CROWE et al., 2017). No entanto, os resultados do presente estudo diferem dos dados relatados para a cana-de-açúcar pré-tratada com ácido (POELKINGS et al., 2015). No trabalho de Poelkings e colaboradores, os entrenós de cana foram amostrados de uma espécie ancestral do gênero Saccharum e de um híbrido moderno com aptidão para produção de açúcar e etanol de primeira geração. O pré-tratamento com ácido pode induzir alterações significantes na biomassa lignocelulósica, como a remoção de xilanas, alterações estruturais na lignina, e deslocamento espacial da lignina nas paredes celulares (DONOHOE et al., 2008). É provável que o pré-tratameto ácido utilizado por Poelkings et al. (2015) não foi brando, e portanto, não produziu resultados similares aos descritos por Crowe et al. (2017). Aparentemente, o efeito do estágio de maturação sucessiva dos entrenós sobre a digestibilidade enzimática não foi observado devido ao efeito pronunciado do pré-tratamento químico.

A hipótese do presente trabalho consistiu na premissa de que pelo menos um dos híbridos selecionados poderia apresentar acúmulo elevado de sacarose e baixo padrão de lignificação nos tecidos do entrenó. Este perfil de maturação do caule poderia indicar características favoráveis para o desenvolvimento de genótipos de cana-de-açúcar com alto teor de sacarose e lignocelulose com baixa recalcitrância. Essas características foram encontradas nos híbridos H89 e H58. Apesar desses híbridos apresentarem uma rápida lignificação dos entrenós (I1 a I5), os teores iniciais de lignina nos entrenós jovens eram menores em relação aos níveis basais dos híbridos H321 e H140 (Figura S2).

Os entrenós jovens dos híbridos H89 e H58 apresentaram alta digestibilidade de glucanas e xilanas sem qualquer pré-tratamento. Enquanto que os teores de sacarose atingiram níveis próximos ao máximo em I5 (Figura S1). Estas características contrastam com o H140, que apresentou um número de entrenós jovens recalcitrantes significativamente maior em relação aos demais híbridos (Figura 2.6). O conteúdo de lignina foi significativamente menor em I1 e I3 em H89 e H58 em comparação a H140, enquanto que o teor de glucanas apresentou um comportamento inverso (Figura 2.5). O teor de xilanas apresentou baixa variabilidade para as amostras neste estudo. 
A existência de valores extremos no conjunto de dados contribuiu para evidenciar que I1 de H140 (16,4\% de lignina) apresentou digestibilidade de glucanas e xilanas inferiores a I1 1 de H89 (18,7\% de lignina). Este contraste entre os dois entrenós, indica que os níveis iniciais de lignina possuem um maior potencial para determinar a recalcitrância em comparação ao progresso de lignificação durante a maturação do entrenó. Dados de estudos anteriores corroboram com a premissa de que em adição à lignina, outras características da composição química da parede celular afeta a recalcitrância (HIMMEL et al., 2007; COSTA et al., 2013; DING et al., 2013; LOQUE et al., 2015; HOLVERDA et al., 2019).

Um modelo de regressão linear simples gerou resultados adequados para a predição da digestibilidade da biomassa lignocelulósica em função do teor de glucanas divido pelo somatório dos teores de lignina e xilanas (Figura 2.7A). A alta capacidade preditiva deste modelo pode ser atribuída a relação inversa entre o teor de glucanas e os teores de lignina e xilanas ao longo dos estágios de maturação dos entrenós. O conteúdo de glucanas nos entrenós representaram não só a celulose, mas também glucanas de ligação mista (um polímero não ramificado de resíduos de glicose com $\beta-1,4$ e $\beta-1,3)$, que são facilmente digeridas por coquetéis enzimáticos comerciais de celulase (VEGA-SANCHEZ et al., 2013; COSTA et al., 2016).

Em resumo, os resultados deste trabalho permitiram a identificação de características fenotípicas desejáveis para o desenvolvimento de híbridos de cana-de-açúcar com aptidão dupla, ou seja, alto rendimento de sacarose e baixa recalcitrância de lignocelulose. Especificamente, essas características foram identificadas nos híbridos H89 e H58. A identificação de marcadores moleculares específicos para a essas características (FERREIRA et al., 2016; SILVA et al., 2017; TAVARES et al., 2018) poderiam ajudar no desenvolvimento de híbridos de cana-de-açúcar que combinem altos rendimentos de sacarose e baixa recalcitrância da lignocelulose.

\section{Conclusões}

Nos híbridos experimentais avaliados houve acúmulo rápido de sacarose do entrenó I1 para I5, enquanto que o acúmulo de lignocelulose aumentou constantemente de I1 para I11. Independente do genótipo, a digestibilidade diminuiu significativamente ao longo dos estágios de maturação do entrenó. $\mathrm{O}$ acúmulo de sacarose e lignocelulose seguiram um padrão similar entre os híbridos. No entanto, o processo de maturação dos entrenós, como por exemplo a lignificação do entrenó, assim como o teor inicial de lignina nos entrenós jovens, 
diferiram entre os híbridos e resultaram em diferenças na recalcitrância. Especificamente, amostras em que a deposição de lignina começou com níveis altos, resultaram em baixas proporções de glucanas e alta recalcitrância do entrenó. No entanto, quando os teores de lignina eram baixos, as amostras apresentaram baixa recalcitrância e maior proporção de glucanas em comparação aos entrenós recalcitrantes. O modelo de regressão linear simples conseguiu capturar essas informações e, portanto, apresentou robustez na predição da digestibilidade de glucanas em função do teor de glucanas divido pelo somatório dos teores de lignina e xilanas.

\section{Agradecimentos}

Este trabalho foi financiado pela FAPESP (2014 / 06923-6), CNPq (308570 / 2017-0 303416 / 2018-1) e Coordenação de Aperfeiçoamento de Pessoal de Nível Superior (CAPES)

- 001 D. Collucci e R.C.A. Bueno agradecem a CAPES e a FAPESP (2016 / 02985-2) pelas bolsas de estudo, respectivamente. Os autores gostariam de agradecer a J. M. Silva pela assistência técnica. 


\section{Figuras e Tabelas Suplementares}

Teores de sacarose, lignocelulose, digestibilidade in vitro de entrenós de cana-de-açúcar em relação ao estágio de maturação e a genótipos de Saccharum.

Tabela S1. Características fenotípicas de 4 genótipos de cana-de-açúcar colhidos após 12 meses de rebrota (cana soca). Médias e desvios padrão foram calculados de 3 repetições experimentais

Híbrido Altura do Número de Posição Comprimento Diâmetro do Entrenó cana caule (m) entrenós do do entrenó Entrenó

in natura

\begin{tabular}{|c|c|c|c|c|c|c|}
\hline & & & entrenó & $(\mathrm{cm})$ & $(\mathrm{cm})$ & (g) \\
\hline \multirow{4}{*}{ H89 } & $1.9 \pm 0.1$ & $18 \pm 1$ & 1 & $6.0 \pm 0.5$ & $2.3 \pm 0.0$ & $25 \pm 2$ \\
\hline & & & 3 & $7.2 \pm 0.9$ & $2.4 \pm 0.2$ & $36 \pm 6$ \\
\hline & & & 5 & $8.6 \pm 1.0$ & $2.4 \pm 0.2$ & $46 \pm 4$ \\
\hline & & & 11 & $13.3 \pm 1.8$ & $2.5 \pm 0.2$ & $72 \pm 5$ \\
\hline \multirow[t]{4}{*}{ H58 } & $2.0 \pm 0.1$ & $18 \pm 3$ & 1 & $7.6 \pm 1.5$ & $2.4 \pm 0.0$ & $33 \pm 3$ \\
\hline & & & 3 & $10.9 \pm 1.9$ & $2.5 \pm 0.1$ & $53 \pm 8$ \\
\hline & & & 5 & $11.4 \pm 1.5$ & $2.6 \pm 0.1$ & $61 \pm 9$ \\
\hline & & & 11 & $13.0 \pm 2.8$ & $2.8 \pm 0.1$ & $72 \pm 22$ \\
\hline \multirow[t]{4}{*}{ H321 } & $2.5 \pm 0.1$ & $24 \pm 4$ & 1 & $5.5 \pm 1.4$ & $2.9 \pm 0.1$ & $28 \pm 9$ \\
\hline & & & 3 & $7.5 \pm 2.0$ & $3.3 \pm 0.1$ & $47 \pm 8$ \\
\hline & & & 5 & $9.8 \pm 2.2$ & $3.4 \pm 0.1$ & $66 \pm 12$ \\
\hline & & & 11 & $10.4 \pm 3.1$ & $3.5 \pm 0.1$ & $80 \pm 24$ \\
\hline \multirow[t]{4}{*}{ H140 } & $2.3 \pm 0.1$ & $22 \pm 2$ & 1 & $4.2 \pm 0.9$ & $2.5 \pm 0.4$ & $19 \pm 5$ \\
\hline & & & 3 & $5.6 \pm 1.0$ & $3.0 \pm 0.1$ & $29 \pm 8$ \\
\hline & & & 5 & $8.8 \pm 1.5$ & $3.0 \pm 0.1$ & $51 \pm 13$ \\
\hline & & & 11 & $11.6 \pm 1.4$ & $2.8 \pm 0.1$ & $77 \pm 16$ \\
\hline
\end{tabular}

Fonte: Arquivo pessoal 
Figura S1. Teores de sacarose e biomassa lignocelulósica de 4 genótipos de cana-de-açúcar em relação à estágios progressivos de maturação do entrenó
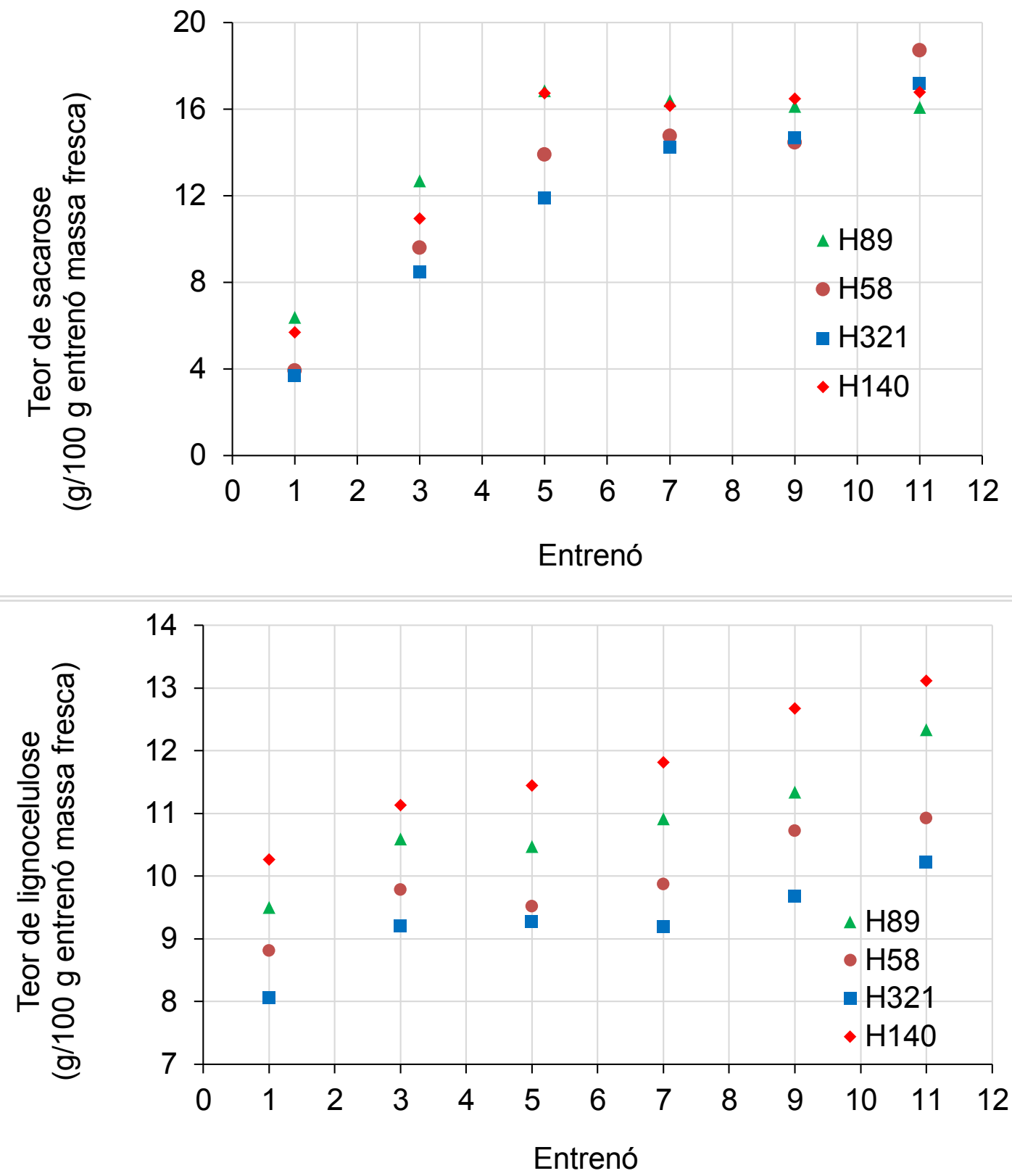

Fonte: Arquivo pessoal 
Figura S2. Composição química da biomassa lignocelulósica em função de estágios de maturação do entrenó de 4 híbridos de cana-de-açúcar
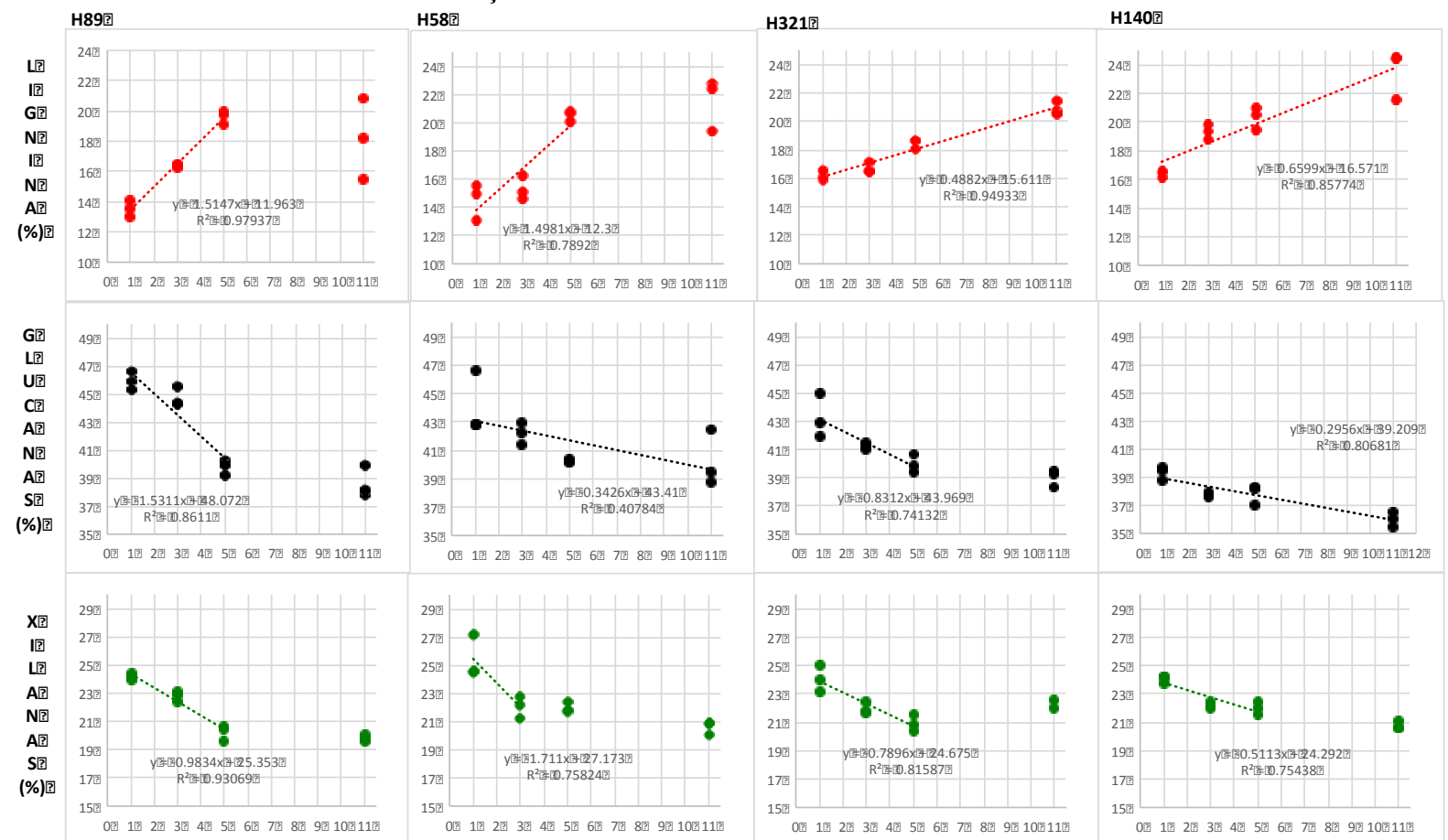

Fonte: Arquivo pessoal 
Figura S3. Cinéticas da conversão de glucanas e xilanas durante a digestibilidade enzimática in vitro de entrenós em estágios sucessivos de maturação de 4 genótipos de cana-de-açúcar
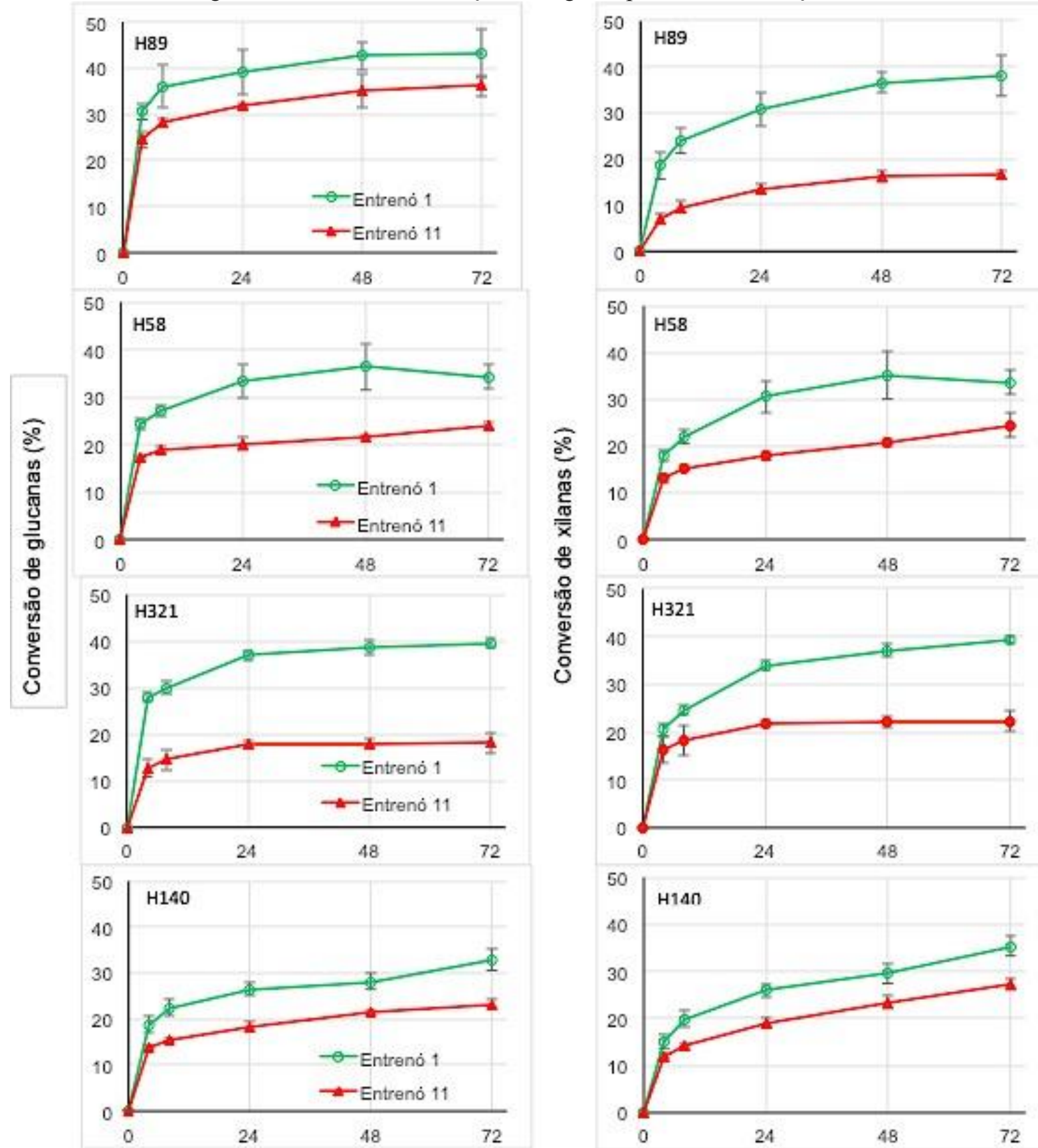

Tempo de hidrólise enzimática(h)

Fonte: Arquivo pessoal 


\section{Capítulo 3}

5 ARTIGO CIENTÍFICO II "Descrição da composição química e da digestibilidade in vitro de amostras de cana-de-açúcar em estágios de desenvolvimento progressivos a partir da análise multivariada de componentes principais"

Este capítulo corresponde ao manuscrito de um artigo científico intitulado: "Descrição da composição química e da digestibilidade in vitro de amostras de cana-de-açúcar em estágios de desenvolvimento progressivos a partir da análise multivariada de componentes principais" de autoria de Daniel Collucci e André Ferraz.

\section{Resumo}

A análise de componentes principais (PCA) envolve a análise multivariada de dados e permite identificar padrões de dados que se correlacionam, levando a identificação de características relevantes em um conjunto de amostras. No presente trabalho, características químicas de amostras de entrenós de 4 híbridos de cana-de-açúcar representando estágios progressivos de desenvolvimento de maturação foram correlacionados com dados de digestibilidade da fração polissacarídica in vitro por meio do emprego de PCA. Os dados mostraram que o primeiro e o segundo componentes principais explicaram juntamente próximo a $90 \%$ da variação no conjunto de dados. O PCA permitiu analisar a relação entre as características químicas da biomassa, os componentes principais, e os grupos (híbridos-entrenós) do conjunto de dados. Os dados levaram à identificação e a segregração entre amostras de cana-de-açúcar provenientes dos 4 híbridos e 4 dos entrenós em estágios de maturação contrastantes e progressivos.

\section{Introdução}

A análise de componentes principais (PCA) é uma técnica estatística não paramétrica utilizada para reduzir a dimensionalidade e obter informações de um conjunto de dados (JOLLIFFE; CADIMA, 2016). O conjunto de dados é comummente composto por $\boldsymbol{p}$ variáveis numéricas e $\boldsymbol{n}$ grupos, de forma que, os valores dos dados definem $\mathrm{p}$ vetores $\mathrm{n}$-dimensionais, ou seja, uma matriz de dados $\boldsymbol{n} \times \boldsymbol{p}=\boldsymbol{X}$ (JOLLIFFE; CADIMA, 2016). A extração da informação do conjunto de dados por PCA começa com a redução da dimensionalidade, essencialmente, a redução da dimensionalidade inicia-se pela identificação da combinação linear das colunas da matriz $\boldsymbol{X}$ com variação máxima (SALDARRIAGA et al., 2018). 
A redução da dimensionalidade nos dados ocorre simultaneamente à redução do número de atributos que apresentam correlação entre si (SALDARRIAGA et al., 2018). Este processo busca reter a máxima variabilidade existente nos dados, porém restringe a avaliação das combinações lineares entre as variáveis, reduzindo assim o número de variáveis avaliadas. Matematicamente, identificar a combinação linear com máxima variância na matriz $\boldsymbol{X}$, é o mesmo que obter um vetor $\boldsymbol{a}$ de dimensão $\boldsymbol{p}$ que maximiza a forma quadrática $\mathbf{a}$ 'Sa; onde $\boldsymbol{a}$ é um vetor de constantes, $\boldsymbol{a}_{1}, \boldsymbol{a}_{2}, \ldots, \boldsymbol{a}_{n}$, ' indica a transposição de vetores, e $\boldsymbol{S}$, é a matrix de covariância dos dados (JOLLIFFE; CADIMA, 2016).

As combinações lineares que maximizam a variância do conjuntos de dados, são comumente denominados de componentes principais (LI et al., 2013). Os componentes principais não são correlacionados, e comumente, são ordenados de maneira que o primeiro componente apresenta a maior variabilidade dos dados em comparação aos demais componentes. A decomposição da matriz de covariância dos dados em autovetores e autovalores permite a representação da variância em um espaço n-dimensional e a clusterização dos dados em grupos com propriedades e características similares (TAHIR et al., 2013). Considerando que as análises multivariadas são comumente empregadas para descrever a variabilidade da variável dependente em função de inúmeras variáveis independentes, o presente trabalho aplicou a técnica de PCA na clusterização de híbridos de cana-de-açúcar e entrenós em diferentes estágios de maturação em função de suas características fenotípicas relativas à composição química e digestibilidade enzimática de seus polissacarídeos.

\section{Metodologia}

Os dados referentes ao teor de fibras, à composição química da biomassa lignocelulósica e a digestibilidade in vitro de glucanas e xilanas foram as variáveis utilizadas para agrupar híbridos de cana-de-açúcar e entrenós em estágios de maturação sucessivos e contrastantes em função de uma análise de componentes principais. A metodologia relativa a obtenção da composição química da biomassa e da digestibilidade enzimática da biomassa dos híbridos utilizados neste estudo estão descritas em destalhes em COLLUCCI et al., 2019. Dados referentes à composição química incluíram os teores de lignina, glucanas e xilanas. Devido a variação na escala entre as variáveis avaliadas, os dados foram normalizados. A normalização das variáveis originais impediu que valores altos no conjunto de dados tivessem expressão significativa na matriz de covariância. A normalização utilizada foi a do tipo L2 
(SUAREZ-ALVAREZ et al., 2012). A matriz de covariância foi calculada utilizando os valores normalizados das variáveis originais. A matriz de covariância contém informações relativas a variabilidade dos dados, esta variabilidade foi representada espacialmente no PCA. A decomposição da matriz de covariância foi realizada pelo cálculo dos autovetores e seus respectivos autovalores. Cada componente principal corresponde a um par autovetorautovalor. A API (application programming interface) scikit-learn foi utilizada para calcular os autovetores e autovalores dos componentes principais, que na realidade corresponderam a projeção ortogonal da variância e a magnitude dessa projeção em um plano espacial (BUITINCK et al., 2013).

\section{Resultados}

Os dados originais analisados empregados no presente estudo estão indicados na Tabela 3.1. A amplitude de dados em cada coluna permite avaliar a região de cobertura de cada propriedade avaliada. Por outro lado, o desvio padrão de dados de cada coluna auxilia na verificação da existência, ou não, de dados acumulados em uma única região de valores experimentais, sendo que desvios elevados indicam uma distribuição menos homogênea de dados (LEMESHKO et al., 2017). Os desvios padrão para os teores de fibra, glucanas, xilanas, lignina e para as digestibilidades de glucanas e xilanas foram, respectivamente, 1.46, $8.04,7.67,1.72,2.81$ e 2.83 . Nota-se que as variações das digestibilidade de glucanas (18.2949.62\%) e xilanas (16.56-47.62\%) são maiores em relação as demais variáveis. Os teores de fibra, xilanas, glucanas e lignina exibiram amplitude de variação de 7,9 11 e 12 pontos percetuais respectivamente. 
Tabela 3.1. Dados analíticos avaliados por PCA, incluindo o teor de fibras, a composição química e a digestibilidade in vitro de amostras de 4 híbridos de cana de açúcar amostrados na forma de 3 indivíduos por híbrido (repetições biológicas) e 4 entrenós por híbrido representando estágios progressivos de desenvolvimento da planta. Total de amostras corresponde a 48.

\begin{tabular}{|c|c|c|c|c|c|c|c|}
\hline Híbrido & 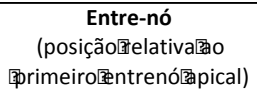 & $\begin{array}{c}\text { Fibra } \\
\text { (g/100 g entrenó } \\
\text { massa fresca) }\end{array}$ & $\begin{array}{c}\text { Digestibilidade xilanas } \\
\text { (Conversão de xilanas após } \\
72 \mathrm{~h} \text { de digestão enzimática) }\end{array}$ & $\begin{array}{l}\text { Digestibilidade glucanas } \\
\text { (Conversão de glucanas após } \\
72 \mathrm{~h} \text { de digestão enzimática) }\end{array}$ & $\begin{array}{c}\text { Xilanas } \\
(\%)\end{array}$ & $\begin{array}{c}\text { Glucanas } \\
(\%)\end{array}$ & $\begin{array}{c}\text { Lignina } \\
(\%)\end{array}$ \\
\hline 58 & i11 & 12.15 & 29.90 & 33.65 & 20.89 & 42.51 & 19.38 \\
\hline 58 & ¡11 & 10.55 & 24.35 & 23.78 & 20.84 & 38.76 & 22.78 \\
\hline 58 & ¡11 & 10.05 & 26.24 & 29.52 & 20.01 & 39.47 & 21.54 \\
\hline 58 & i55 & 9.65 & 18.63 & 28.73 & 22.40 & 40.19 & 20.78 \\
\hline 58 & i55 & 9.23 & 17.26 & 23.89 & 21.64 & 40.39 & 20.65 \\
\hline 58 & i55 & 9.65 & 16.74 & 23.24 & 21.82 & 40.27 & 20.11 \\
\hline 58 & i3 & 9.53 & 36.76 & 36.23 & 22.70 & 42.88 & 15.27 \\
\hline 58 & i3 & 9.73 & 23.97 & 23.47 & 22.21 & 42.22 & 15.10 \\
\hline 58 & i3 & 10.09 & 38.35 & 33.13 & 21.20 & 41.44 & 16.28 \\
\hline 58 & i1 & 8.68 & 47.17 & 49.01 & 24.65 & 42.80 & 15.00 \\
\hline 58 & i1 & 8.95 & 34.70 & 35.43 & 24.55 & 42.85 & 15.51 \\
\hline 58 & i1 & 8.79 & 47.42 & 49.62 & 27.18 & 46.58 & 13.05 \\
\hline 89 & i11 & 11.54 & 19.12 & 34.61 & 20.03 & 39.93 & 18.21 \\
\hline 89 & i11 & 14.26 & 16.56 & 36.13 & 19.67 & 37.80 & 16.07 \\
\hline 89 & ¡11 & 11.20 & 19.56 & 31.27 & 20.34 & 38.17 & 20.88 \\
\hline 89 & i55 & 9.79 & 32.48 & 33.35 & 20.62 & 40.25 & 20.00 \\
\hline 89 & ¡55 & 11.41 & 31.47 & 32.29 & 19.62 & 39.24 & 19.70 \\
\hline 89 & ¡55 & 10.21 & 33.94 & 33.22 & 20.43 & 39.92 & 19.09 \\
\hline 89 & i3 & 10.41 & 39.04 & 35.73 & 22.46 & 44.27 & 16.53 \\
\hline 89 & i3 & 10.68 & 30.08 & 33.75 & 22.89 & 44.32 & 16.35 \\
\hline 89 & ¡3 & 10.69 & 27.90 & 32.49 & 23.12 & 45.53 & 16.29 \\
\hline 89 & i1 & 9.85 & 44.92 & 47.29 & 24.17 & 45.91 & 13.52 \\
\hline 89 & i1 & 8.65 & 38.07 & 43.23 & 24.42 & 46.55 & 12.98 \\
\hline 89 & i1 & 9.99 & 43.65 & 44.90 & 24.53 & 45.32 & 14.11 \\
\hline 140 & i11 & 12.16 & 27.75 & 21.27 & 20.64 & 36.03 & 24.51 \\
\hline 140 & ¡11 & 12.89 & 27.34 & 23.30 & 21.02 & 36.56 & 22.49 \\
\hline 140 & i11 & 14.27 & 22.81 & 22.64 & 20.62 & 35.46 & 24.44 \\
\hline 140 & i55 & 10.55 & 26.34 & 22.78 & 22.05 & 38.32 & 20.46 \\
\hline 140 & ¡55 & 11.67 & 30.54 & 25.99 & 21.53 & 37.04 & 20.93 \\
\hline 140 & i55 & 12.11 & 27.79 & 19.60 & 22.00 & 38.20 & 19.50 \\
\hline 140 & i3 & 10.91 & 31.83 & 26.42 & 22.51 & 37.97 & 18.78 \\
\hline 140 & i3 & 10.73 & 35.17 & 29.05 & 22.00 & 37.74 & 19.39 \\
\hline 140 & i3 & 11.74 & 30.66 & 25.08 & 22.15 & 37.62 & 19.77 \\
\hline 140 & i1 & 8.53 & 30.35 & 27.49 & 24.22 & 39.65 & 16.36 \\
\hline 140 & i1 & 11.06 & 32.12 & 32.84 & 24.23 & 39.48 & 16.13 \\
\hline 140 & i1 & 11.18 & 31.65 & 29.37 & 23.70 & 38.71 & 16.60 \\
\hline 321 & ¡11 & 11.05 & 23.41 & 20.34 & 21.96 & 39.30 & 20.72 \\
\hline 321 & ¡11 & 10.48 & 16.71 & 18.29 & 22.61 & 39.47 & 21.44 \\
\hline 321 & i11 & 9.11 & 27.13 & 24.44 & 18.42 & 38.37 & 20.53 \\
\hline 321 & i55 & 9.88 & 28.27 & 29.10 & 21.52 & 40.63 & 18.62 \\
\hline 321 & i55 & 9.60 & 37.84 & 34.22 & 20.80 & 39.81 & 18.61 \\
\hline 321 & i55 & 8.32 & 34.32 & 32.70 & 20.35 & 39.35 & 18.10 \\
\hline 321 & i3 & 9.09 & 28.42 & 27.00 & 22.50 & 41.22 & 17.17 \\
\hline 321 & ¡3 & 9.25 & 32.60 & 28.08 & 21.68 & 41.01 & 16.54 \\
\hline 321 & ¡3 & 9.24 & 25.47 & 32.85 & 21.76 & 41.49 & 16.38 \\
\hline 321 & i1 & 8.18 & 36.42 & 36.30 & 25.04 & 44.92 & 15.89 \\
\hline 321 & i1 & 8.31 & 39.32 & 39.48 & 23.95 & 42.87 & 16.06 \\
\hline 321 & i1 & 7.67 & 43.53 & 42.47 & 23.16 & 41.97 & 16.54 \\
\hline Média & & 10.29 & 30.54 & 31.23 & 22.14 & 40.64 & 18.23 \\
\hline Desvio伭adrão & & 1.46 & 8.04 & 7.67 & 1.72 & 2.81 & 2.83 \\
\hline
\end{tabular}

Fonte: Arquivo pessoal

A Figura 3.1 indica uma análise de correlação realizada entre todas as variáveis estudadas. A correlação entre a digestibilidade de glucanas e o teor de glucanas $(0.73)$ foi a maior dentre as correlações positivas. A correlação entre a digestibilidade de glucanas e o teor de lignina (-0.76) e as correlações entre os teores de xilanas e glucanas e o teor de lignina, se destacaram dentre as correlações negativas entre as variáiveis. 
Figura 3.1. Análise de correlação entre as variáveis do conjunto de dados avaliados que inclui o teor de fibras, a composição química e a digestibilidade in vitro de amostras de 4 híbridos de cana de açúcar amostrados na forma de 3 indivíduos por híbrido (repetições biológicas) e 4 entrenós por híbrido representando estágios progressivos de desenvolvimento da planta. Total de amostras corresponde a 48 .

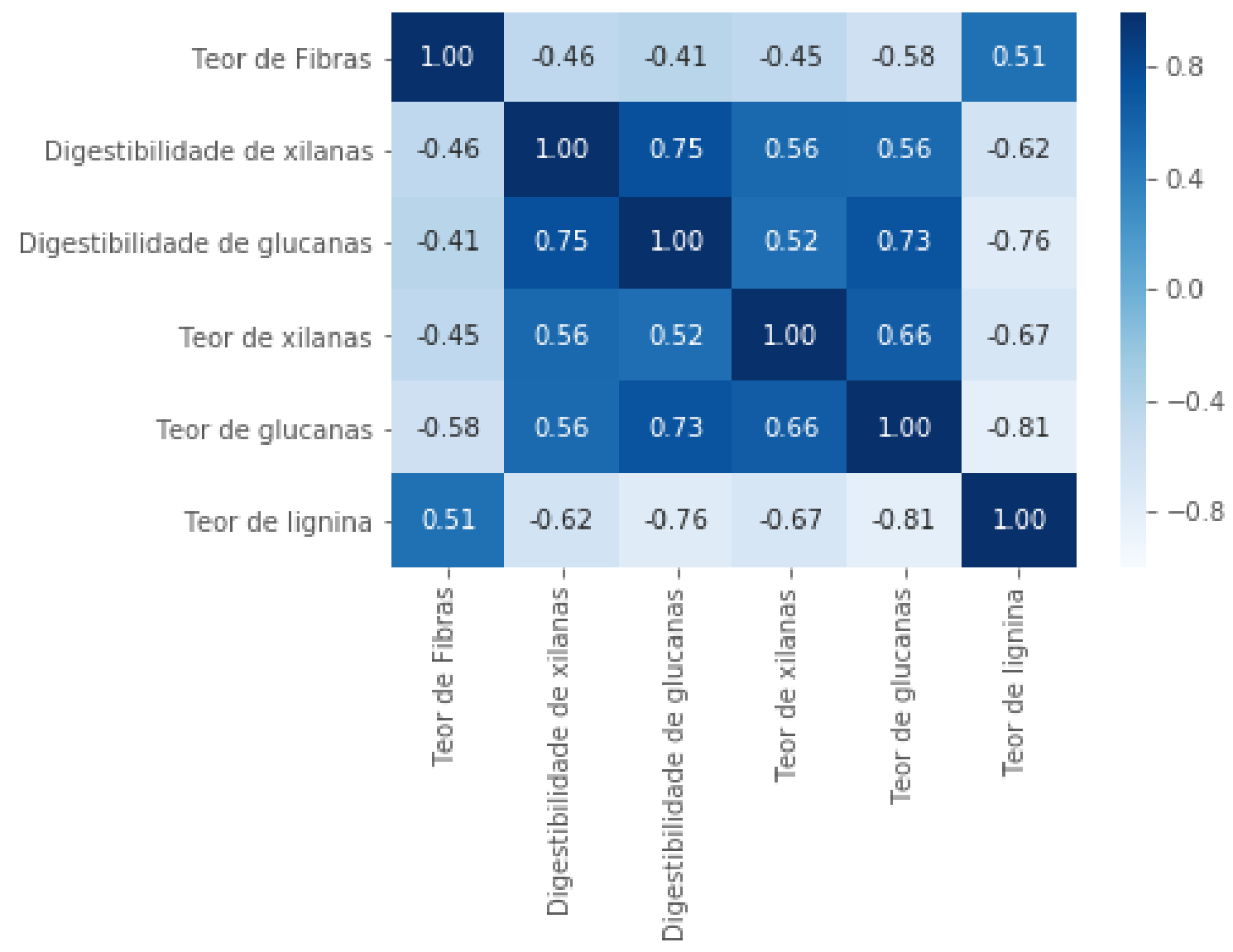

Fonte: Arquivo pessoal

Os dados descritos na Tabela 3.1 foram normalizados e estão indicados na Tabela 3.2. Nota-se que a normalização nivela a variabilidade dos dados em relação aos dados não normalizados. Os desvios padrão para as variáveis normalizadas relativos aos teores de fibra, glucanas, xilanas, lignina e digestibilidade in vitro de glucanas e xilanas foram respectivamente $0.02,0.04,0.03,0.01,0.01$ e 0.02 . 
Tabela 3.2. Dados normalizados das propriedades descritas na Tabela 1 e utilizados na análise de componentes principais (PCA).

\begin{tabular}{|c|c|c|c|c|c|c|c|}
\hline Híbrido & 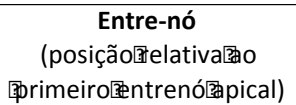 & Fibra & Digestibilidade glucanas & Digestibilidade xilanas & Xilanas & Glucanas & Lignina \\
\hline 58 & i11 & 0.17 & 0.14 & 0.15 & 0.14 & 0.15 & 0.15 \\
\hline 58 & ¡11 & 0.15 & 0.11 & 0.11 & 0.14 & 0.14 & 0.18 \\
\hline 58 & ¡11 & 0.14 & 0.12 & 0.13 & 0.13 & 0.14 & 0.17 \\
\hline 58 & ¡55 & 0.13 & 0.09 & 0.13 & 0.15 & 0.14 & 0.16 \\
\hline 58 & ¡55 & 0.13 & 0.08 & 0.11 & 0.14 & 0.14 & 0.16 \\
\hline 58 & ¡55 & 0.13 & 0.08 & 0.10 & 0.14 & 0.14 & 0.16 \\
\hline 58 & ¡3 & 0.13 & 0.17 & 0.16 & 0.15 & 0.15 & 0.12 \\
\hline 58 & i3 & 0.14 & 0.11 & 0.11 & 0.14 & 0.15 & 0.12 \\
\hline 58 & i3 & 0.14 & 0.18 & 0.15 & 0.14 & 0.15 & 0.13 \\
\hline 58 & i1 & 0.12 & 0.22 & 0.22 & 0.16 & 0.15 & 0.12 \\
\hline 58 & ¡1 & 0.12 & 0.16 & 0.16 & 0.16 & 0.15 & 0.12 \\
\hline 58 & ¡1 & 0.12 & 0.22 & 0.22 & 0.18 & 0.17 & 0.10 \\
\hline 89 & ¡11 & 0.16 & 0.09 & 0.16 & 0.13 & 0.14 & 0.14 \\
\hline 89 & ¡11 & 0.20 & 0.08 & 0.16 & 0.13 & 0.13 & 0.13 \\
\hline 89 & ¡11 & 0.16 & 0.09 & 0.14 & 0.13 & 0.14 & 0.16 \\
\hline 89 & ¡55 & 0.14 & 0.15 & 0.15 & 0.13 & 0.14 & 0.16 \\
\hline 89 & ¡55 & 0.16 & 0.14 & 0.15 & 0.13 & 0.14 & 0.15 \\
\hline 89 & ¡55 & 0.14 & 0.16 & 0.15 & 0.13 & 0.14 & 0.15 \\
\hline 89 & i3 & 0.14 & 0.18 & 0.16 & 0.15 & 0.16 & 0.13 \\
\hline 89 & i3 & 0.15 & 0.14 & 0.15 & 0.15 & 0.16 & 0.13 \\
\hline 89 & i3 & 0.15 & 0.13 & 0.15 & 0.15 & 0.16 & 0.13 \\
\hline 89 & i1 & 0.14 & 0.21 & 0.21 & 0.16 & 0.16 & 0.11 \\
\hline 89 & ¡1 & 0.12 & 0.17 & 0.19 & 0.16 & 0.16 & 0.10 \\
\hline 89 & ¡1 & 0.14 & 0.20 & 0.20 & 0.16 & 0.16 & 0.11 \\
\hline 140 & ¡11 & 0.17 & 0.13 & 0.10 & 0.13 & 0.13 & 0.19 \\
\hline 140 & ¡11 & 0.18 & 0.13 & 0.10 & 0.14 & 0.13 & 0.18 \\
\hline 140 & i11 & 0.20 & 0.10 & 0.10 & 0.13 & 0.13 & 0.19 \\
\hline 140 & ¡55 & 0.15 & 0.12 & 0.10 & 0.14 & 0.14 & 0.16 \\
\hline 140 & ¡55 & 0.16 & 0.14 & 0.12 & 0.14 & 0.13 & 0.16 \\
\hline 140 & ¡55 & 0.17 & 0.13 & 0.09 & 0.14 & 0.14 & 0.15 \\
\hline 140 & i3 & 0.15 & 0.15 & 0.12 & 0.15 & 0.13 & 0.15 \\
\hline 140 & i3 & 0.15 & 0.16 & 0.13 & 0.14 & 0.13 & 0.15 \\
\hline 140 & i3 & 0.16 & 0.14 & 0.11 & 0.14 & 0.13 & 0.15 \\
\hline 140 & ¡1 & 0.12 & 0.14 & 0.12 & 0.16 & 0.14 & 0.13 \\
\hline 140 & ¡1 & 0.15 & 0.15 & 0.15 & 0.16 & 0.14 & 0.13 \\
\hline 140 & ¡1 & 0.16 & 0.14 & 0.13 & 0.15 & 0.14 & 0.13 \\
\hline 321 & i11 & 0.15 & 0.11 & 0.09 & 0.14 & 0.14 & 0.16 \\
\hline 321 & ¡11 & 0.15 & 0.08 & 0.08 & 0.15 & 0.14 & 0.17 \\
\hline 321 & ¡11 & 0.13 & 0.12 & 0.11 & 0.12 & 0.14 & 0.16 \\
\hline 321 & ¡55 & 0.14 & 0.13 & 0.13 & 0.14 & 0.14 & 0.15 \\
\hline 321 & ¡55 & 0.13 & 0.17 & 0.15 & 0.14 & 0.14 & 0.15 \\
\hline 321 & ¡55 & 0.12 & 0.16 & 0.15 & 0.13 & 0.14 & 0.14 \\
\hline 321 & ¡3 & 0.13 & 0.13 & 0.12 & 0.15 & 0.15 & 0.13 \\
\hline 321 & ¡3 & 0.13 & 0.15 & 0.13 & 0.14 & 0.15 & 0.13 \\
\hline 321 & ¡3 & 0.13 & 0.12 & 0.15 & 0.14 & 0.15 & 0.13 \\
\hline 321 & i1 & 0.11 & 0.17 & 0.16 & 0.16 & 0.16 & 0.12 \\
\hline 321 & i1 & 0.12 & 0.18 & 0.18 & 0.16 & 0.15 & 0.13 \\
\hline 321 & i1 & 0.11 & 0.20 & 0.19 & 0.15 & 0.15 & 0.12 \\
\hline Média & & 0.14 & 0.14 & 0.14 & 0.14 & 0.14 & 0.14 \\
\hline Desvioథpadrão & & 0.02 & 0.04 & 0.03 & 0.01 & 0.01 & 0.02 \\
\hline
\end{tabular}

Fonte: Arquivo pessoal

Os dados normalizados indicados na Tabela 3.2 foram analizados por PCA. A Figura 3.2 indica a variabilidade explicada pelo conjunto de componentes principais. Somente os componentes principais que explicaram grande parte da variabilidade nos dados foram selecionados. Especificamente, dois componentes foram selecionados; o primeiro componente 
(PC1), explicou próximo a $80 \%$ da variância contida nos dados; o segundo componente (PC2), explicou pouco mais que $10 \%$ da variabilidade dos dados. (Figura 3.2).

Figura 3.2. Variância dos dados explicada por cada um dos componentes principais calculados a partir da PCA aplicada aos dados da Tabela 3.2. a) variância dos dados atribuída a cada componente principal. b) variância cumulativa em função dos componentes principais
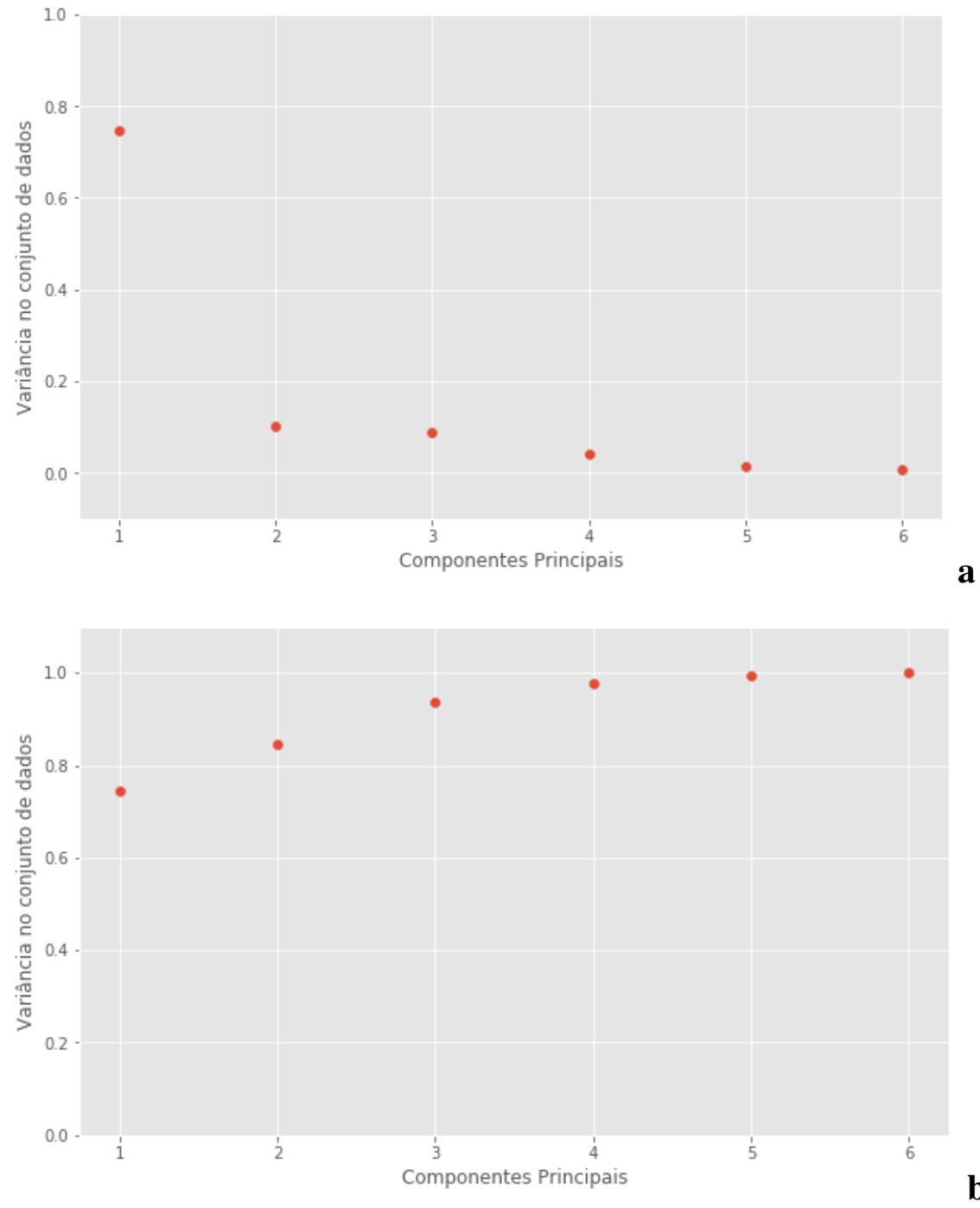

Fonte: Arquivo pessoal

A análise exploratória dos autovetores e dos autovalores dos dados permitiu a identificação da relação entre as variáveis originais, os componentes principais, e as classes do conjunto de dados (Figura 3.3). Aparentemente, a análise de componentes principais permitiu a identificação de 3 grupos de entrenós: os entrenós maduros e lignificados dos híbridos H140 e H321, os entrenós jovens e pouco lignificados com alta digestibilidade de glucanas e xilanas dos híbridos H89 e H58 e os entrenós maduros e pouco lignificados dos híbridos $\mathrm{H} 89$. 
Figura 3.3 Representação dos híbridos-entrenóes (símbolos) de cada amostra calculados para os componentes principais 1 e 2 e dos autovetores (setas) calculados pela PCA.

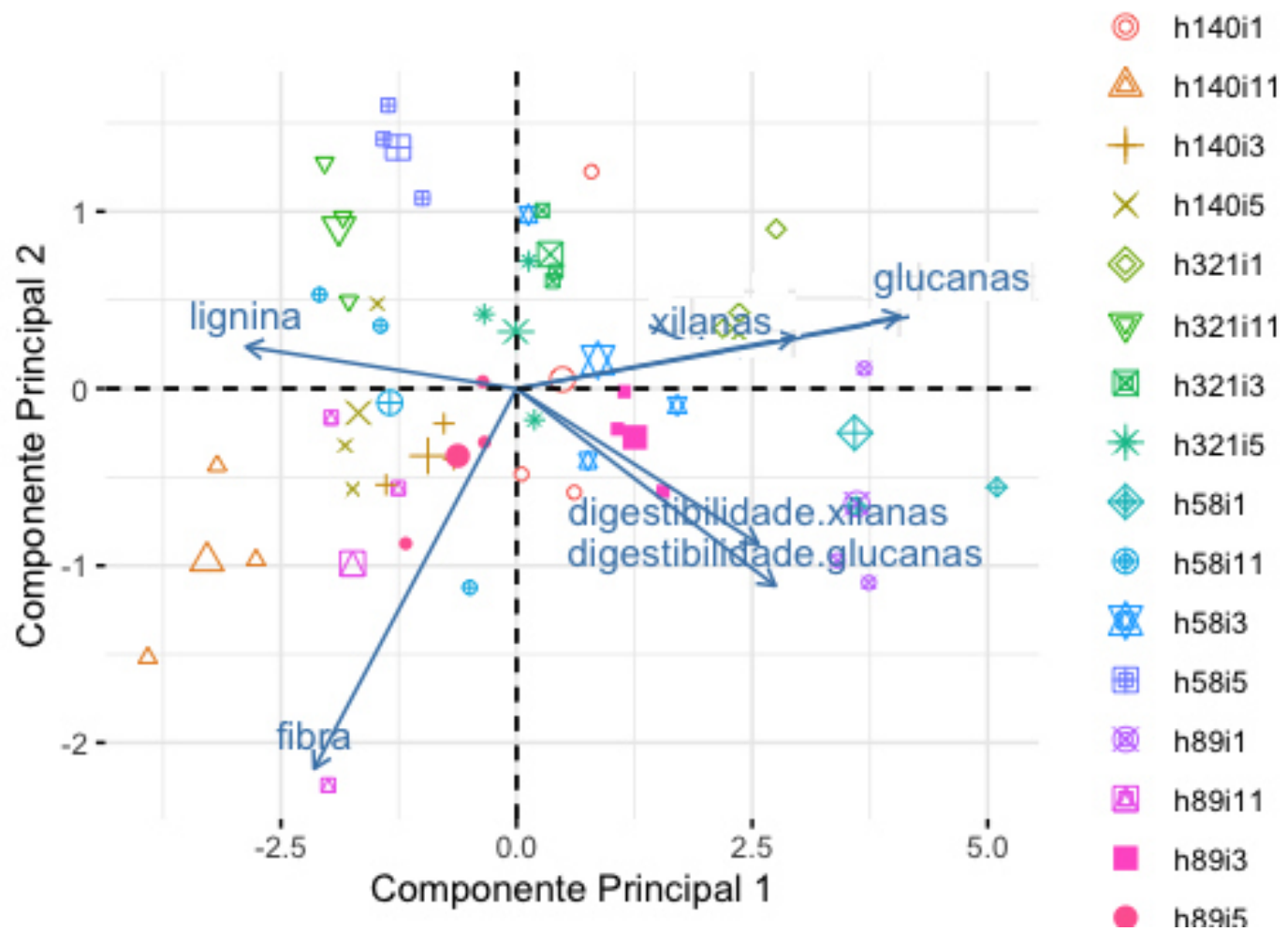

Fonte: Arquivo pessoal

\section{Discussão}

Uma análise de componentes principais foi realizada visando a segregação entre amonstras de entrenós em estágios de maturação progressivos de 4 híbridos de cana-deaçúcar. Modificações na composição química da biomassa dos entrenós da cana-de-açúcar ocorrem durante o desenvolvimento vegetativo (LINGLE; THOMSON, 2012). Especificamente, tecidos jovens contém baixo teor de lignina em relação aos demais componentes da parede celular, como xilanas e glucanas (JUNG; CASLER, 2006). Por outro lado, a medida que os tecidos envelhecem, as paredes celulares sofrem um enriquecimento do conteúdo de lignina (JUNG; CASLER, 2006). As correlações entre os teores de glucanas e xilanas e o teor de lignina na biomassa dos entrenós foram -0.81 e -0.67 respectivamente, e refletem as modificações na composição química das paredes celulares durante 0 desenvolvimento vegativo dos entrenós, pois à medida que as paredes celulares se tornam lignificadas, ocorre o aumento na densidade do material, devido ao acúmulo exclusivo de lignina, diminuindo, proporcionalmente, os teores de polissacarídeos. 
A correlação entre a digestibilidade de glucanas e o teor de lignina foi uma das mais expressíveis dentre as correlações negativas (Figura 3.1). A correlação negativa entre essas duas variáveis também reflete as mudanças que ocorrem durante a maturação dos entrenós da cana-de-acúcar (LINGLE; THOMSON, 2012). Essencialmente, nos entrenós mais jovens, o teor de lignina é menor em relação aos entrenós maduros; o aumento do teor de lignina na biomassa dos entrenós, e o respectivo aumento do encapsulamento das microfibrilas de celulose pela lignina, dificultam o acesso de enzimas as cadeias de celulose, e consequentemente, reduzem a digestibilidade das glucanas à hidrólise enzimática (PETRIDIS; SMITH, 2018).

Os resuldados da análise de PCA indicaram que aproxidamente $90 \%$ da variabilidade no conjunto de dados foram explicados por 2 componentes principais (Figura 3.2). As direções e as magnitudes dos autovetores do PCA estão ilustrados na Figura 3.3. O sentido inverso das direções dos autovetores relativos a digestibilidade de glucanas e xilanas em relação a direção do autovetor relativo a lignina colaboram com estudos anteriores que descrevem a relação inversa entre a disgestibilidade da biomassa da cana-de-açúcar e o teor de lignina (COSTA et al., 2016). Os resultados do presente estudo demonstraram que o PCA permite a segregação e a clusterização visual de híbridos que apresentam caracterísiticas similares no que diz respeito ao acúmulo de biomassa e a maturação dos entrenós e a respectiva deposição de lignina.

\section{Conclusões}

O PCA possibilitou a segregação entre os grupos de híbridos e entrenós. Especificamente, por meio do PCA, 3 clusters de híbridos-entrenós foram identificados: os entrenós maduros e lignificados dos híbridos H140 e H321, os entrenós jovens e pouco lignificados com alta digestibilidade de glucanas e xilanas dos híbridos H89 e H58 e os entrenós maduros e pouco lignificados do híbridos H89. 


\section{CONCLUSÕES GERAIS DA TESE}

As principais conclusões desta tese foram obtidas em função da avaliação experimental do processo de maturação da cana-de-açúcar avaliada por amostragem de entrenós em estágios progressivos de desenvolvimento. Os dados mostraram que houve acúmulo rápido de sacarose entre os entrenós I1 para I5, independentemente do híbrido avaliado. Por outro lado, o acúmulo de lignocelulose aumentou constantemente entre os entrenós I1 até I11, também independentemente do híbrido avaliado. A digestibilidade da biomassa lignocelulósica destes entrenós diminuiu significativamente entre os entrenós I1 até I11, mas foi dependente do híbrido em estudo. Destaca-se, por exemplo, que o entrenó I11 do híbrido H89 foi menos recalcitrante do que o entrenó I1 do híbrido H140.

O acúmulo de sacarose e lignocelulose seguiram um padrão similar entre os híbridos. No entanto, o processo de maturação dos entrenós, como por exemplo a lignificação do entrenó, assim como o teor inicial de lignina nos entrenós jovens, diferiram entre os híbridos e resultaram em diferenças na recalcitrância. Especificamente, amostras em que a deposição de lignina começou com níveis altos, resultaram em baixas proporções de glucanas e alta recalcitrância do entrenó. No sentido inverso, quando os teores de lignina eram baixos nos entrenós imaturos, as amostras apresentaram baixa recalcitrância e maior proporção de glucanas em comparação aos entrenós recalcitrantes. Analisando o conjunto de dados completo foi possível mostrar que um modelo de regressão linear simples conseguiu capturar essas informações e descrever a digestibilidade de glucanas como uma função do teor de glucanas divido pelo somatório dos teores de lignina e xilanas.

A análise dos dados por PCA permitiu corroborar quantitativamente a discriminação de amostras e mostrar que os autovetores do teor de lignina e de digestibilidade apresentaram sentidos inversos, bem como os autovetores do teor de glucana e de digestibilidade apresentaram o mesmo sentido. Em termos de perspectivas abertas pelo presente estudo podese inferir que a identificação de marcadores moleculares que diferenciem os híbridos de cana avaliados pode ser uma ferramenta de seleção rápida destas características que permitiria acelerar os processos de seleção de novos híbridos a partir da técnica de hibridação de parentes com características já conhecidas. 


\section{REFERÊNCIAS}

BONNETT, G. D.; Developmental Stages (Phenology) In: MOORE, P. H.; BOTHA, F. C. (Ed.). Sugarcane: Physiology, Biochemistry \& Functional Biology. New Jersey, US: John Wiley \& Sons, 2013. p. 35-50.

BOTTCHER, A.; CESARINO, I.; DOS SANTOS, A. B.; VICENTINI, R.; MAYER, J. L. S.; VANHOLME, R.; MORREEL, K.; GOEMINNE, G.; MOURA, J. C . M. S.; NOBILE, P. M.; CARMELLO-GUERREIRO, S. M.; DOS ANJOS, I. A.; CRESTE, S.; BOERJAN, W.; DE LANDELL, M. G. A.; MAZZAFERA, P. Lignification in sugarcane: biochemical characterization, gene discovery, and expression analysis in two genotypes contrasting for lignin content. Plants Physiol, v. 163, p. 1539-1557, 2013.

BRADY, S. M.; BUROW, M.; BUSCH, W.; CARLBORG, Ö.; DENBY, K. J.; GLAZEBROOK, J.; HAMILTON, E. S.; HARMER, S. L.; HASWELL, E. S.; MALOOF, J. N.; SPRINGER, N.M. Reassess the t test: interact with all your data via ANOVA. The Plant Cell. vol. 27 n.8, p.2088-2094. 2015.

BRIENZO, M.; ABUD, Y.; FERREIRA, S.; CORRALES, R. C. N. R.; FERREIRALEITÃO, V. S.; SOUZA, W.; SANT'ANNA, C. Characterization of anatomy, lignina distribution, and response to pretreatments of sugarcane culm node and internode. Ind Crop Prod, v. 84, p. 305-313, 2016.

BUITINCK, L.; LOUPPE, G.; BLONDEL, M.; PEDREGOSA, F.; MUELLER, A.; GRISEL, O.; NICULAE, V.; PRETTENHOFER, P.; GRAMFORT, A.; GROBLER, J.; LAYTON, R. API design for machine learning software: experiences from the scikit-learn project. arXiv, preprint arXiv:1309.0238. 2013.

BURTON, R. A.; WILSON, S. M.; HRMOVA, M.; HARVEY, A. J.; SHIRLEY, N. J.; MEDHURST, A.; STONE, B. A.; NEWBIGIN, E. J.; BACIC, A; FINCHER, G. B. Cellulose synthase-like CslF genes mediate the synthesis of cell wall $(1,3 ; 1,4)-\beta-D-$ glucans. Science, v. 311, n.5769, p. 1940-1942, 2006.

BUSSE- WICHER, M.; GOMES, T. C.; TRYFONA, T.; NIKOLOVSKI, N.; STOTT, K.; GRANTHAM, N. J.; BOLAM, D. N.; SKAF, M. S.; DUPREE, P. The pattern of xylan acetylation suggests xylan may interact with cellulose microfibrils as a twofold helical screw in the secondary plant cell wall of Arabidopsis thaliana. The Plant Journal, v. 79, n. 3, p. 492-506, 2014.

CAO, P. J.; BARTLEY, L. E.; JUNG, K. H.; RONALD, P. C. Construction of a rice glycosyltransferase phylogenomic database and identification of rice-diverged glycosyltransferases. Molecular Plant, v. 1, n. 5, p. 858-877, 2008.

CARPITA, N. C.; GIBEAUT, D. M. Structural models of primary cell walls in flowering plants: consistency of molecular structure with the physical properties of the walls during growth. Plant J, v. 3, p. 1-30, 1993.

CARPITA, N. C., Update on mechanisms of plant cell wall biosynthesis: how plants make cellulose and other $(1 \rightarrow 4)-\beta$-D-glycans. Plant physiology, 155(1), p. 171-184, 2011. 
CASS, C. L.; LAVELL, A. A.; SANTORO, N.; FOSTER, C. E.; KARLEN, S. D.; SMITH, R. A.; RALPH, J.; GARVIN, D. F; SEDBROOK, J. C. Cell wall composition and biomass recalcitrance differences within a genotypically diverse set of Brachypodium distachyon inbred lines. Frontiers in plant science, v. 7, p. 708, 2016.

CHANDEL, A. K.; ANTUNES, F. A.; DE ARRUDA, P. V.; MILESSI, T. S.; DA SILVA, S. S; DE ALMEIDA FELIPE, M. D. G. Dilute acid hydrolysis of agro-residues for the depolymerization of hemicellulose: state-of-the-art. d-xylitol. Berlin, Heidelberg: Springer, 2012. p. 39-61.

CHEN, W. H.; YE, S. C.; SHEEN, H. K. Hydrolysis characteristics of sugarcane bagasse pretreated by dilute acid solution in a microwave irradiation environment. Applied Energy, v. 93, p. 237-244, 2012.

CHONG, S. L.; VIRKKI, L.; MAAHEIMO, H.; JUVONEN, M.; DERBA-MACELUCH, M.; KOUTANIEMI, S.; ROACH, M.; SUNDBERG, B.; TUOMAINEN, P.; MELLEROWICZ, E. J.; TENKANEN, M. O-Acetylation of glucuronoxylan in Arabidopsis thaliana wild type and its change in xylan biosynthesis mutants. Glycobiology, v. 24, n. 6, p. 494-506, 2014.

COlluCCI, D.; BUENO, R. C.; MILAGRES, A. M; FERRAZ, A. Sucrose content, lignocellulose accumulation and in vitro digestibility of sugarcane internodes depicted in relation to internode maturation stage and Saccharum genotypes. Industrial Crops and Products, vol. 139, n.2, p.111543. 2019.

COSGROVE, D. J. Growth of the plant cell wall. Nature reviews molecular cell biology, v. 6, n. 11, p. 850, 2005.

COSGROVE, D. C. Comparative structure and biomechanics of plant primary and secondary cell walls. Frontiers in plant science, v. 3, p. 204, 2012.

COSTA, T. H. F.; MASARIN, F.; BONIFÁCIO, T. O.; MILAGRES, A. M. F.; FERRAZ, A. The enzymatic recalcitrance of internodes of sugar cane hybrids with contrasting lignin contents. Ind Crop Prod, v. 51, p. 202-211, 2013.

COSTA, T. H.; VEGA-SÁNCHEZ, M. E.; MILAGRES, A. M.; SCHELLER, H. V.; FERRAZ, A. Tissue-specific distribution of hemicelluloses in six different sugarcane hybrids as related to cell wall recalcitrance. Biotechnology for biofuels, v. 9, n. 1, p. 99, 2016.

CROWE, J. D.; FERINGA, N.; PATTATHIL, S.; MERRITT, B.; FOSTER, C.; DINES, D.; ONG, R. G.; HODGE, D. B. Identification of developmental stage and anatomical fraction contributions to cell wall recalcitrance in switchgrass. Biotechnology for biofuels, v. 10, n. 1, p.184, 2017.

DE SOUZA, A. P.; LEITE, D. C.; PATTATHIL, S.; HAHN, M. G.; BUCKERIDGE, M. S. Composition and structure of sugarcane cell wall polysaccharides: implications for secondgeneration bioethanol production. BioEnergy Research, v. 6, n. 2, p. 564-579, 2013.

DEMARTINI, J. D.; PATTATHIL, S.; MILLER, J. S.; LI, H.; HAHN, M. G.; WYMAN, C. E. Investigating plant cell wall components that affect biomass recalcitrance in poplar and switchgrass. Energy Environ Sci, v. 6, p. 898-909, 2013. 
DIEN, B. S.; SARATH, G.; PEDERSEN, J. F.; SATTLER, S. E.; CHEN, H.; FUNNELLHARRIS, D. L.; NICHOLS, N. N.; COTTA, M. A. Improved sugar conversion and ethanol yield for forage sorghum (Sorghum bicolor L. Moench) lines with reduced lignin contents. BioEnergy Research, v. 2, n. 3, p. 153-164, 2009.

DING, S-Y.; LIU, Y-S.; ZENG, Y.; HIMMEL, M. E.; BAKER, J. O.; BAYER, E. A. How does plant cell wall nanoscale architecture correlate with enzymatic digestibility? Science, $v$. 338, p. 1055-1059, 2012.

DOBLIN, M. S.; KUREK, I.; JACOB-WILK, D.; DELMER, D. P. Cellulose biosynthesis in plants: from genes to rosettes. Plant and cell physiology, v. 43, n. 12, p. 1407-1420, 2002.

DONOHOE, B. S.; DECKER, S. R.; TUCKER, M. P.; HIMMEL, M. E.; VINZANT, T. B. Visualizing lignin coalescence and migration through maize cell walls following thermochemical pretreatment. Biotechnology and bioengineering, v. 101, n. 5, p. 913-925, 2008 .

DRIOUICH, A.; CHEVALIER, L.; VICRÉ, M.; LEROUXEL, O. Golgi-mediated synthesis and secretion of matrix polysaccharides of the primary cell wall of higher plants. Frontiers in Plant Science, v. 3, p. 79, 2012.

DROUET, J. L.; PAGÈS, L. GRAAL: a model of GRowth, Architecture and carbon ALlocation during the vegetative phase of the whole maize plant: model description and parameterisation. Ecological Modelling, v. 165, n. 2-3, p. 147-173, 2003.

EDWARDS, G. E. VOZNESENSKAYA, E. V. C 4 photosynthesis: Kranz forms and singlecell $\mathrm{C} 4$ in terrestrial plants. In $\mathrm{C} 4$ photosynthesis and related $\mathrm{CO} 2$ concentrating mechanisms. Dordrecht: Springer, 2010. p. 29-61.

FAIK, A. Xylan biosynthesis: news from the grass. Plant physiology, v. 153, n. 2, p. 396402, 2010.

FERRAZ, A., BAEZA, J., RODRIGUEZ, J., FREER, J. Estimating the chemical composition of biodegraded pine and eucalyptus wood by DRIFT spectroscopy and multivariate analysis. Bioresource Technol, v. 74, p. 201-212, 2000.

FERREIRA, S. S.; HOTTA, C. T.; DE CARLI POELKING, V. G.; LEITE, D. C. C.; BUCKERIDGE, M. S.; LOUREIRO, M. E.; BARBOSA, M. H. P.; CARNEIRO, M. S.; SOUZA, G. M. Co-expression network analysis reveals transcription factors associated to cell wall biosynthesis in sugarcane. Plant molecular biology, v. 91, n. 1-2, p. 15-35, 2016.

FRANK, A. B.; BERDAHL, J. D.; HANSON, J. D.; LIEBIG, M. A.; JOHNSON, H. A. Biomass and carbon partitioning in switchgrass. Crop Science, v. 44, n. 4, p.1391-1396, 2004.

FRASER, C. M.; CHAPPLE, C. The phenylpropanoid pathway in Arabidopsis. The Arabidopsis Book/American Society of Plant Biologists, v. 9, 2011. 
FRY, S.C. The structure and functions of xyloglucan. Journal of Experimental Botany, v. 40, n. 1, pp.1-11, 1989.

GIBEAUT, D. M. Nucleotide sugars and glycosyltransferases for synthesis of cell wall matrix polysaccharides. Plant Physiology and Biochemistry, v. 38, n. 1-2, p. 69-80, 2000.

GRABBER, J. H.; RALPH, J.; HATFIELD, R. D. Ferulate cross-links limit the enzymatic degradation of synthetically lignified primary walls of maize. Journal of Agricultural and Food Chemistry, v. 46, n. 7, p. 2609-2614,1998.

GRABBER, J. H. How do lignin composition, structure, and cross-linking affect degradability? A review of cell wall model studies. Crop Science, v. 45, n. 3, p .820-831, 2005.

GRABBER, J. H. Relationships between cell wall digestibility and lignin content as influenced by lignin type and analysis method. Crop Science, v. 59, n. 3, p. 1122-1132, 2019.

GUO, M.; SONG, W., 2018. The growing US bioeconomy: Drivers, development and constraints. New biotechnology, v. 49, p. 48-57, 2018.

GUPTA, R.; LEE, Y. Y. Pretreatment of corn stover and hybrid poplar by sodium hydroxide and hydrogen peroxide. Biotechnology Progress, v. 26, n. 4, p. 1180-1186, 2010.

GUERRIERO, G.; FUGELSTAD, J.; BULONE, V. What do we really know about cellulose biosynthesis in higher plants? Journal of Integrative Plant Biology, v. 52, n. 2, p. 161-175, 2010.

GOWIK, U.; WESTHOFF, P. The path from C3 to C4 photosynthesis. Plant Physiology, v. 155, n. 1, p. 56-63, 2011.

HABIBI, Y.; LUCIA, L. A.; ROJAS, O. J. Cellulose nanocrystals: chemistry, self-assembly, and applications. Chemical reviews, v. 110, n. 6, p. 3479-3500, 2010.

HAIGLER, C. H.; IVANOVA-DATCHEVA, M.; HOGAN, P. S.; SALNIKOV, V. V.; HWANG, S.; MARTIN, K.; DELMER, D. P. Carbon partitioning to cellulose synthesis. In: Plant Cell Walls. Dordrecht: Springer, 2001, p. 29-51.

HALPIN, C. Lignin engineering to improve saccharification and digestibility in grasses. Current opinion in biotechnology, v. 56, p .223-229, 2019.

HARRIS, P. J.; HARTLEY, R. D. Phenolic constituents of the cell walls of monocotyledons. Biochem System Ecol, v. 8, p. 153-60, 1980.

HARRIS, P. J.; TRETHEWEY, J. A. The distribution of ester-linked ferulic acid in the cell walls of angiosperms. Phytochemistry Reviews, v. 9, n. 1, p. 19-33, 2010.

HERRMANN, K. M. The shikimate pathway: early steps in the biosynthesis of aromatic compounds. The Plant Cell, v. 7, n. 7, p. 907, 1995. 
HIS, I.; DRIOUICH, A.; NICOL, F.; JAUNEAU, A.; HÖFTE, H. Altered pectin composition in primary cell walls of korrigan, a dwarf mutant of Arabidopsis deficient in a membranebound endo-1, 4- $\beta$-glucanase. Planta, v. 212, n. 3, p. 348-358, 2001.

HOLWERDA, E. K., WORTHEN, R. S., KOTHARI, N., LASKY, R. C., DAVISON, B. H., FU, C., WANG, Z. Y., DIXON, R. A., BISWAL, A. K., MOHNEN, D.; NELSON, R. S. Multiple levers for overcoming the recalcitrance of lignocellulosic biomass. Biotechnology for biofuels, v. 12, n. 1, p.15, 2019.

HSIEH, Y. S.; HARRIS, P. J. Xyloglucans of monocotyledons have diverse structures. Molecular Plant, v. 2, n. 5, p. 943-965, 2009.

HUBBELL, C. A.; RAGAUSKAS, A. J. Effect of acid-chlorite delignification on cellulose degree of polymerization. Bioresource technology, v. 101, n. 19, p. 7410-7415, 2010.

HUISMAN, M. M. H.; WEEL, K. G. C.; SCHOLS, H. A.; VORAGEN, A. G. J. Xyloglucan from soybean (Glycine max) meal is composed of XXXG-type building units. Carbohydrate Polymers, v. 42, n. 2, p. 185-191, 2000.

HUMPHREYS, J. M.; CHAPPLE, C. Rewriting the lignin roadmap. Current opinion in plant biology, v. 5, n. 3, p. 224-229, 2002.

JOLLIFFE, I.T.; CADIMA, J. Principal component analysis: a review and recent developments. Philosophical Transactions of the Royal Society A: Mathematical, Physical and Engineering Sciences, v. 374, n. 2065, p.20150202. 2016.

JUNG, H. G.; CASLER, M. D. Maize stem tissues: impact of development on cell wall degradability. Crop Sci, v. 46, p. 1801-1809, 2006.

JUNG, H. J. G. Forage digestibility: the intersection of cell wall lignification and plant tissue anatomy. In: ANNUAL FLORIDA RUMINANT NUTRITION SYMPOSIUM. 23., Proceedings... p. 162-174, 2012. Gainesville, Florida. of the 23rd

KIM, M.; DAY, D. F. Composition of sugar cane, energy cane, and sweet sorghum suitable for ethanol production at Louisiana sugar mills. J Ind Microbiol Biotechnol, v. 38, p. 803$807,2011$.

KLEMM, D.; HEUBLEIN, B.; FINK, H. P.; BOHN, A. Cellulose: fascinating biopolymer and sustainable raw material. Angewandte Chemie International Edition, v. 44, n. 22, p. 3358-3393, 2005.

KUMAR, D. AND MURTHY, G. S. Stochastic molecular model of enzymatic hydrolysis of cellulose for ethanol production. Biotechnology for biofuels, v. 6, n. 1, p.63, 2013.

KUMAR, P.; BARRETT, D. M.; DELWICHE, M. J; STROEVE, P. Methods for pretreatment of lignocellulosic biomass for efficient hydrolysis and biofuel production. Industrial \& engineering chemistry research, v. 48, n. 8, p. 3713-3729, 2009. 
LAKSHMANAN, P.; GEIJSKES, R. J.; AITKEN, K. S.; GROF, C. L.; BONNETT, G. D.; SMITH, G. R. Sugarcane biotechnology: the challenges and opportunities. In Vitro Cellular \& Developmental Biology. Plant, v. 41, n. 4, p. 345-363, 2005.

LAM, T. B. T.; LIYAMA, K.; STONE, B. A. Hot alkali-labile linkages in the walls of the forage grass Phalaris aquatica and Lolium perenne and their relation to in vitro wall digestibility. Phytochemistry, v. 64, p. 603-607, 2003.

LAURITO-FRIEND, D. F.; MENDES, F. M.; REINOSO, F. M.; FERRAZ, A.; MILAGRES, A. M. F. Sugarcane hybrids with original low lignin contents and high field productivity are useful to reach high glucose yields from bagasse. Biomass and Bioenergy, v.75, p. 65-74, 2015.

LAZARIDOU, A.; BILIADERIS, C. G. Molecular aspects of cereal $\beta$-glucan functionality: Physical properties, technological applications and physiological effects. Journal of cereal science, v. 46, n. 2, p. 101-118, 2007.

LEE, C.; TENG, Q.; HUANG, W.; ZHONG, R.; YE, Z. H. The Arabidopsis family GT43 glycosyltransferases form two functionally nonredundant groups essential for the elongation of glucuronoxylan backbone. Plant physiology, v. 153, n. 2, p. 526-541, 2010.

LEMESHKO, B. Y.; VERETELNIKOVA, I. V.; LEMESHKO, S. B.; NOVIKOVA, A.Y. Application of homogeneity tests: problems and solution. In: INTERNATIONAL CONFERENCE ON ANALYTICAL AND COMPUTATIONAL METHODS IN PROBABILITY THEORY, p. 461-475. 2017.

LI, L.; CHENG, X.F.; LESHKEVICH, J.; UMEZAWA, T.; HARDING, S.A.; CHIANG, V.L. The last step of syringyl monolignol biosynthesis in angiosperms is regulated by a novel gene encoding sinapyl alcohol dehydrogenase. The Plant Cell, v. 13, n. 7, p. 1567-1586, 2001.

LI, Y., WANG, N. AND CARROLL, R.J. Selecting the number of principal components in functional data. Journal of the American Statistical Association, v. 108, n. 504, p.12841294. 2013.

LINGLE, S. E.; TEW, T.L. A comparison of growth and sucrose metabolism in sugarcane germplasm from Louisiana and Hawaii. Crop Science, v. 48, n. 3, p. 1155-1163, 2008.

LINGLE, S. E., THOMSON, J. L. Sugarcane internode composition during crop development. BioEnergy Research, v. 5, n. 1, p. 168-178, 2012.

LOQUE, D.; SCHELLER, H. V; PAULY, M. Engineering of plant cell walls for enhanced biofuel production. Current opinion in plant biology, v. 25, p.151-161, 2015.

LOUREIRO, M. E.; BARBOSA, M. H.; LOPES, F. J.; SILVÉRIO, F. O. Sugarcane breeding and selection for more efficient biomass conversion in cellulosic ethanol. In: Routes to cellulosic ethanol. New York, NY: Springer, 2011, p. 199-239.

MACDONALD, M. J., D'CUNHA, G. B. A modern view of phenylalanine ammonia lyase. Biochemistry and Cell Biology, v. 85, n. 3, p. 273-282, 2007. 
MAO, L.; QUE, F.; WANG, G. Sugar metabolism and involvement of enzymes in sugarcane (Saccharum officinarum L.) stems during storage. Food chemistry, v. 98, n. 2, p. 338-342, 2006.

MASARIN, F.; GURPILHARES, D. B.; BAFFA, D. C. F.; BARBOSA, M. H. P.; CARVALHO, W.; FERRAZ, A.; MILAGRES, A. M. F. Chemical composition and enzymatic digestibility of sugarcane clones selected for varied lignin contents. Biotechnol Biofuels, v. 4, n. 55, 2011.

MASARIN, F.; NEVES, A. S.; MILAGRES, A. M.; FERRAZ, A. Evaluation of a simple alkaline pretreatment for screening of sugarcane hybrids according to their in vitro digestibility. Ind Crops Prod, v. 51, p. 390-395, 2013.

MCCARTNEY, L.; MARCUS, S. E.; KNOX, J. P. Monoclonal antibodies to plant cell wall xylans and arabinoxylans. J Histochem Cytochem, v. 53, n. 4, p. 5435, 2005.

MCKINLEY, B. A.; OLSON, S. N.; RITTER, K. B.; HERB, D. W.; KARLEN, S. D.; LU, F.; RALPH, J.; ROONEY, W. L.; MULLET, J. E. Variation in energy sorghum hybrid TX08001 biomass composition and lignin chemistry during development under irrigated and nonirrigated field conditions. PloS one, 13(4), p.e0195863, 2018.

MEIKLE, P.J.; HOOGENRAAD, N. J.; BONIG, I.; CLARKE, A. E.; STONE, B. A. A (13,1-4)-betaglucan- specific monoclonal antibody and its use in the quantitation and immunocytochemical location of (1-3,1-4)-beta-glucans. Plant J, v. 5, p. 1-9, 1994

MENDES, F. M.; HEIKKILÄ, E.; FONSECA, M. B.; MILAGRES, A. M. F.; FERRAZ, A.; FARDIM, P. Topochemical characterization of sugar cane pretreated with alkaline sulfite. Ind Crop Prod, v. 69, p. 60-67, 2015.

MENDES, F. M.; VASCONCELOS, M. H.; DIAS, M. O. S.; FERRAZ, A.; MILAGRES, A. M. F.; SANTOS, J. C.; JESUS, C. D. F.; WATANABE, M. D. B.; JUNQUEIRA, T. L.; BONOMI, A. Alkaline sulfite pretreatment for integrated first and second generation ethanol production: A techno-economic assessment of sugarcane hybrids. Biomass and Bioenergy, v. 119, p. 314-321, 2018.

MOON, R. J.; MARTINI, A.; NAIRN, J.; SIMONSEN, J.; YOUNGBLOOD, J. Cellulose nanomaterials review: structure, properties and nanocomposites. Chemical Society Reviews, v. 40, n. 7, p. 3941-3994, 2011.

MOORE, K.J.; MOSER, L. E. Quantifying developmental morphology of perennial grasses. Crop Science, v. 35, n. 1, p. 37-43, 1995.

MOREIRA, L.R.S. Insights into the mechanism of enzymatic hydrolysis of xylan. Applied microbiology and biotechnology, v. 100, n. 12, p. 5205-5214, 2016.

MULLET, J.E. High-biomass C4 grasses-Filling the yield gap. Plant science, v. 261, p.10$17,2017$.

MUTWIL, M.; DEBOLT, S.; PERSSON, S. Cellulose synthesis: a complex complex. Current opinion in plant biology, v. 11, n. 3, p. 252-257, 2008. 
NISHIYAMA, Y.; SUGIYAMA, J.; CHANZY, H.; LANGAN, P. Crystal structure and hydrogen bonding system in cellulose I $\alpha$ from synchrotron X-ray and neutron fiber diffraction. Journal of the American Chemical Society, v. 125, n. 47, 14300-14306, 2003.

OIKAWA, A.; LUND, C. H.; SAKURAGI, Y.; SCHELLER, H. V. Golgi-localized enzyme complexes for plant cell wall biosynthesis. Trends in plant science, v. 18, n. 1, p. 49-58, 2013.

PARK, S.; BAKER, J. O.; HIMMEL, M. E.; PARILLA, P. A.; JOHNSON, D. K. Cellulose crystallinity index: measurement techniques and their impact on interpreting cellulase performance. Biotechnol Biofuels, v. 3, n. 10, 2010.

PARK, Y. B.; COSGROVE, D. J. Xyloglucan and its interactions with other components of the growing cell wall. Plant and Cell Physiology, v. 56, n. 2, p.180-194, 2015.

PARK, Y. B.; COSGROVE, D. J. A revised architecture of primary cell walls based on biomechanical changes induced by substrate-specific endoglucanases. Plant Physiology, v. 158, n. 4, p. 1933-1943, 2012.

PATTATHIL, S.; AVCI, U.; BALDWIN, D.; SWENNES, A. G.; MCGILL, J. A.; POPPER, Z.; BOOTTEN, T.; ALBERT, A.; DAVIS, R. H.; CHENNAREDDY, C.; DONG, R.; O'SHEA, B.; ROSSI, R.; LEOFF, C.; FRESHOUR, G.; NARRA, R.; O'NEIL, M.; YORK, W. S.; HAHN, M. G. A comprehensive toolkit of plant cell wall glycan-directed monoclonal antibodies. Plant Physiol, v. 153, p. 514-525, 2010.

PAUlY, M.; QIN, Q.; GREENE, H.; ALBERSHEIM, P.; DARVILL, A.; YORK, W. S. Changes in the structure of xyloglucan during cell elongation. Planta, v. 212, n. 5, p. 842$850,2001$.

PAULY, M.; KEEGSTRA, K. Cell-wall carbohydrates and their modification as a resource for biofuels. Plant J, v. 54, n. 4, p. 559-68, 2008.

PEÑA, M. J.; KULKARNI, A. R.; BACKE, J.; BOYD, M.; O’NEILL, M. A.; YORK, W. S. Structural diversity of xylans in the cell walls of monocots. Planta, v. 244, n. 3, p. 589-606, 2016.

PENG, L.; KAWAGOE, Y.; HOGAN, P.; DELMER, D. Sitosterol- $\beta$-glucoside as primer for cellulose synthesis in plants. Science, v. 295, n. 5552, p. 147-150, 2002.

PETRIDIS, L.; SMITH, J. C. Molecular-level driving forces in lignocellulosic biomass deconstruction for bioenergy. Nature Reviews Chemistry, 2, p. 382-389, 2018.

PINTO, P. C.; EVTUGUIN, D. V.; PASCOAL-NETO, C. Structure of hardwood glucuronoxylans: modifications and impact on pulp retention during wood kraft pulping. Carbohydrate Polymers, v. 60,. n. 4, p. 489-497, 2005.

POELKING, V. G.; GIORDANO, A.; RICCI-SILVA, M. E.; WILLIAMS, T. C. R.; PEÇANHA, D. A.; VENTRELLA, M. C.; RENCORET, J.; RALPH, J.; BARBOSA, M. H. P.; LOUREIRO, M. Analysis of a modern hybrid and an ancient sugarcane implicates a 
complex interplay of factors in affecting recalcitrance to cellulosic ethanol production. PloS one, v. 10, n. 8, p.e0134964, 2015.

RAGAUSKAS, A. J.; BECKHAM, G. T.; BIDDY, M. J.; CHANDRA, R.; CHEN, F.; DAVIS, M. F.; DAVISON, B. H.; DIXON, R. A.; GILNA, P.; KELLER, M.; LANGAN, P. Lignin valorization: improving lignin processing in the biorefinery. Science, v. 344, n. 6185, p. 1246843-1246843-10, 2014.

RALPH, J.; LAPIERRE, C.; BOERJAN, W. Lignin structure and its engineering. Current opinion in biotechnology, v. 56, p. 240-249, 2019.

RANCOUR, D. M.; HATFIELD, R. D.; MARITA, J. M.; ROHR, N. A.; SCHMITZ, R. J. Cell wall composition and digestibility alterations in Brachypodium distachyon achieved through reduced expression of the UDP-arabinopyranose mutase. Front Plant Sci, v. 6, n. 446, 2015.

RENNIE, E. A.; SCHELLER, H. V. Xylan biosynthesis. Curr. Opin. Biotechnol, v. 26, p. 100-107, 2014.

REZENDE, C. A.; DE LIMA, M. A.; MAZIERO, P.; DEAZEVEDO, E. R.; GARCIA, W.; POLIKARPOV, I. Chemical and morphological characterization of sugarcane bagasse submitted to a delignification process for enhanced enzymatic digestibility. Biotechnology for biofuels, v. 4, n. 1, p. 54, 2011.

ROBERT, S.; MOUILLE, G.; HÖFTE, H. The mechanism and regulation of cellulose synthesis in primary walls: lessons from cellulose-deficient Arabidopsis mutants. Cellulose, v. 11, n. 3-4, p. 351-364, 2004.

ROLLIN, J. A.; ZHU, Z.; SATHITSUKSANOH, N.; ZHANG, Y. H. P. Increasing cellulose accessibility is more important than removing lignin: A comparison of cellulose solvent based lignocellulose fractionation and soaking in aqueous ammonia. Biotechnology and bioengineering, v. 108, n. 1, p. 22-30, 2011.

SAGE, R. F.; ZHU, X. G. Exploiting the engine of C4 photosynthesis. Journal of Experimental Botany, v. 62, n. 9, p. 2989-3000, 2011.

SAGE, R. F.; SAGE, T. L.; KOCACINAR, F. Photorespiration and the evolution of C4 photosynthesis. Annual review of plant biology, v. 63, p.19-47, 2012.

SAldARRIAGA, J. F.; GAlleGO, J. L.; LÓPEZ, J. E.; AGUADO, R. OLAZAR, M., Selecting monitoring variables in the manual composting of municipal solid waste based on principal component analysis. Waste and Biomass Valorization, p.1-9, 2018.

SALMÉN, L. Micromechanical understanding of the cell-wall structure. Comptes rendus biologies, v. 327, n. 9, 873-880, 2004.

SANT'ANNA, C.; COSTA, L. T.; ABUD, Y.; BIANCATTO, L.; MIGUENS, F. C.; DE SOUZA, W. Sugarcane cell wall structure and lignin distribution investigated by confocal and electron microscopy. Microscopy research and technique, v. 76, n. 8, p.829-834, 2013. 
SANTOS, L. V.; GRASSI, M. C. B.; GALlARDO, J. C. M.; PIROLlA, R. A. S; CALDERÓN, L. L.; CARVALHO-NETTO, O. V.; PARREIRAS, L. S.; CAMARGO, E. L. O.; DREZZA, A. L.; MISSAWA, S. K.; TEIXEIRA, G. S.; LUNARDI, I.; BRESSIANI, J.; PEREIRA G. A. G. Second-generation ethanol: the need is becoming a reality. Industrial Biotechnology, v. 12: p., 40-57, 2016.

SCHELLER, H. V.; ULVSKOV, P. Hemicelluloses. Annual review of plant biology, v. 61, p. 263-289, 2010.

SCHULTINK, A.; LIU, L.; ZHU, L.; PAULY, M. Structural diversity and function of xyloglucan sidechain substituents. Plants, v. 3, n. 4, p. 526-542, 2014.

SCORDIA, D.; COSENTINO, S. L.; JEFFRIES, T. W. Second generation bioethanol production from Saccharum spontaneum L. spp. Aegyptiacum (Willd.) Hack. Bioresource technology, v. 101, n. 14, p. 5358-5365, 2010.

SEGATO, F.; DAMÁSIO, A. R.; DE LUCAS, R. C.; SQUINA, F. M.; PRADE, R. A. Genomics review of holocellulose deconstruction by aspergilli. Microbiology and Molecular Biology Reviews, v. 78, n. 4, p. 588-613, 2014.

SHELDON, R.A. Green and sustainable manufacture of chemicals from biomass: state of the art. Green Chemistry, v. 16, n. 3, p. 950-963, 2014.

SILVA, L. A.; GASPARINI, K.; ASSIS, C.; RAMOS, R.; KIST, V.; BARBOSA, M. H. P.; TEOFILO, R. F.; BHERING, L. L. Selection strategy for indication of crosses between potential sugarcane genotypes aiming at the production of bioenergy. Industrial Crops and Products, 104, p. 62-67, 2017.

SIQUEIRA, G.; MILAGRES, A. M. F.; CARVALHO, W.; KOCH, G.; FERRAZ, A. Topochemical distribution of lignin and hydroxycinnamic acids in sugar-cane cell walls and its correlation with the enzymatic hydrolysis of polysaccharides. Biotechnol Biofuels, v. 4, n. 7, 2011.

SIQUEIRA, G.; VÁRNAI, A.; FERRAZ, A.; MILAGRES, A. M. Enhancement of cellulose hydrolysis in sugarcane bagasse by the selective removal of lignin with sodium chlorite. Applied Energy, v. 102, p. 399-402, 2013.

SOMERVILlE, C.; BAUER, S.; BRININSTOOL, G.; FACETTE, M.; HAMANN, T.; MILNE, J.; OSBORNE, E.; PAREDEZ, A.; PERSSON, S.; RAAB, T.; VORWERK, S. Toward a systems approach to understanding plant cell walls. Science, v. 306, n. 5705, p. 2206-2211, 2004.

SOMERVILlE, C. Cellulose synthesis in higher plants. Annu. Rev. Cell Dev. Biol., v. 22, p. 53-78, 2006.

SØRENSEN, I., PETTOLINO, F. A.; WILSON, S. M.; DOBLIN, M. S.; JOHANSEN, B.; BACIC, A.; WILLATS, W. G. Mixed- linkage $(1 \rightarrow 3),(1 \rightarrow 4)-\beta$ - d- glucan is not unique to the Poales and is an abundant component of Equisetum arvense cell walls. The Plant Journal, v. 54, n. 3, p. 510-521, 2008. 
STERJIADES, R.; DEAN, J. F.; ERIKSSON, K. E. L. Laccase from sycamore maple (Acer pseudoplatanus) polymerizes monolignols. Plant Physiology, v. 99, n. 3, p. 1162-1168, 1992.

STERJIADES, R.; DEAN, J. F.; GAMBLE, G.; HIMMELSBACH, D. S.; ERIKSSON, K. E. L. Extracellular laccases and peroxidases from sycamore maple (Acer pseudoplatanus) cellsuspension cultures. Planta, v. 190, n. 1, p. 75-87, 1993.

ŠTURCOVÁ, A.; HIS, I.; APPERLEY, D. C.; SUGIYAMA, J.; JARVIS, M. C. Structural details of crystalline cellulose from higher plants. Biomacromolecules, v. 5, n. 4, p. 13331339, 2004.

SUAREZ-ALVAREZ, M. M.; PHAM, D. T.; PROSTOV, M. Y.; PROSTOV, Y. I. Statistical approach to normalization of feature vectors and clustering of mixed datasets. Proceedings of the Royal Society A: Mathematical, Physical and Engineering Sciences, v. 468, n. 2145, p. 2630-2651, 2012.

SUHARDI, V. S. H.; PRASAI, B.; SAMAHA, D.; BOOPATHY, R. Combined biological and chemical pretreatment method for lignocellulosic ethanol production from energy cane.

Bioresour, v. 1, n. 1, p. 2052-6237, 2013.

SUZUKI, S.; LI, L.; SUN, Y. H.; CHIANG, V. L. The cellulose synthase gene superfamily and biochemical functions of xylem-specific cellulose synthase-like genes in Populus trichocarpa. Plant physiology, v. 142, n. 3, p. 1233-1245, 2006.

TAHIR, M.; RAHMAN, H.; GUL, R.; ALI A.; KHALID, M. Genetic divergence in sugarcane genotypes. American Journal of Experimental Agriculture, v. 3, n. 1, p. 102, 2013.

TAVARES, R. G.; LAKSHMANAN, P.; PEITER, E.; O'CONNELL, A.; CALDANA, C.; VICENTINI, R.; SOARES, J. S.; MENOSSI, M. ScGAI is a key regulator of culm development in sugarcane. Journal of Experimental Botany, v. 69, p.3823-3837, 2018.

TURNER, W.; BOTHA, F. C. Purification and kinetic properties of UDP-glucose dehydrogenase from sugarcane. Archives of Biochemistry and Biophysics, v. 407, n. 2, p. 209-216, 2002.

UYS, L.; BOTHA, F. C.; HOFMEYR, J. H. S.; ROHWER, J. M. Kinetic model of sucrose accumulation in maturing sugarcane culm tissue. Phytochemistry, v. 68, n. 16, 2375-2392, 2007.

VAN DYK, J. S.; PLETSCHKE, B. I. A review of lignocellulose bioconversion using enzymatic hydrolysis and synergistic cooperation between enzymes-factors affecting enzymes, conversion and synergy. Biotechnology advances, v. 30, n. 6, p. 1458-1480, 2012.

VANHOLME, R.; DEMEDTS, B.; MORREEL, K.; RALPH, J.; BOERJAN, W. Lignin biosynthesis and structure. Plant physiology, v. 153, n. 3, p. 895-905, 2010.

VANHOLME, R.; DE MEESTER, B.; RALPH, J.; BOERJAN, W. Lignin biosynthesis and its integration into metabolism. Current opinion in biotechnology, v. 56, p. 230-239, 2019. 
VEGA-SÁNCHEZ, M. E.; VERHERTBRUGGEN, Y.; CHRISTENSEN, U.; CHEN, X.; SHARMA, V.; VARANASI, P.; JOBLING, S. A.; TALBOT, M.; WHITE, R. G.; JOO, M.; SINGH, S.; AUER, M.; SCHELLER, H. V.; RONALD, P. C. Loss of Cellulose SynthaseLike F6 function affects mixed-linkage glucan deposition, cell wall mechanical properties and defense responses in vegetative tissues of rice. Plant Physiol, v. 159, n. 1, p. 56-69, 2012.

VEGA-SÁNCHEZ, M. E.; VERHERTBRUGGEN, Y.; SCHELLER, H. V.; RONALD, P. C. Abundance of mixed linkage glucan in mature tissues and secondary cell walls of grasses. Plant Signal Behav, v. 8, n. 2, 2013.

VERMA, A. K.; UPADHYAY, S. K.; VERMA, P. C.; SOLOMON, S.; SINGH, S. B. Functional analysis of sucrose phosphate synthase (SPS) and sucrose synthase (SS) in sugarcane (Saccharum) cultivars. Plant Biology, v. 13, n. 2, p. 325-332, 2011.

VINCKEN, J. P.; BELDMAN, G.; VORAGEN, A. G. Substrate specificity of endoglucanases: what determines xyloglucanase activity? Carbohydrate research, v. 298, n. 4, p, 299-310, 1997.

XU, C.; ARANCON, R. A. D.; LABIDI, J.; LUQUE, R. Lignin depolymerisation strategies: towards valuable chemicals and fuels. Chemical Society Reviews, v. 43, n. 22, p. 7485-7500, 2014.

WACLAWOVSKY, A. J.; SATO, P. M.; LEMBKE, C.G.; MOORE, P. H.; SOUZA, G. M. Sugarcane for bioenergy production: an assessment of yield and regulation of sucrose content. Plant Biotechnol J, v. 8, p. 263-276, 2010.

WAGNER, A.; RALPH, J.; AKIYAMA, T.; FLINT, H.; PHILLIPS, L.; TORR, K.; TE KIRI, L. Exploring lignification in conifers by silencing hydroxycinnamoyl-CoA: shikimate hydroxycinnamoyltransferase in Pinus radiata. Proceedings of the National Academy of Sciences, v. 104, n. 28, p. 11856-11861, 2007.

WANG, J.; NAYAK, S.; KOCH, K.; MING, R. Carbon partitioning in sugarcane (Saccharum species). Frontiers in plant science, v. 4, p.201-207, 2013.

WILSON, J. R.; HATFIELD, R. D. Structural and chemical changes of cell wall types during stem development: consequences for fibre degradation by rumen microflora. Crop and Pasture Science, v. 48, n. 2, p. 165-180, 1997.

WYMAN, C. E.; DALE, B. E.; ELANDER, R. T.; HOLTZAPPLE, M.; LADISCH, M. R.; LEE, Y. Y. Coordinated development of leading biomass pretreatment technologies. Bioresource technology, v. 96, n. 18, p. 1959-1966, 2005.

YANG, B.; WYMAN, C.E. BSA treatment to enhance enzymatic hydrolysis of cellulose in lignin containing substrates. Biotechnol. Bioeng. v. 94, p. 611-617, 2006.

YANG, F.; MITRA, P.; ZHANG, L.; PRAK, L.; VERHERTBRUGGEN, Y.; KIM, J.-S.; SUN, L.; ZHENG, K.; TANG, K.; AUER, M.; SCHELLER, H. V.; LOQUÉ, D. Engineering secondary cell wall deposition in plants. Plant Biotechnol J, v. 11, p. 325-335, 2013. 
YANG, X.; TODD, J.; ARUNDALE, R.; BINDER, J.B.; LUO, Z.; ISLAM, M.S.; SOOD, S. WANG, J. Identifying loci controlling fiber composition in polyploid sugarcane (Saccharum spp.) through genome-wide association study. Industrial Crops and Products. vol. 130, p. 598-605. 2019.

YOUSSEFIAN, S.; AND RAHBAR, N. Molecular origin of strength and stiffness in bamboo fibrils. Scientific reports, 5, p.11116-11129, 2015.

ZHAO, Q.; NAKASHIMA, J.; CHEN, F.; YIN, Y.; FU, C.; YUN, J.; DIXON, R. A. Laccase is necessary and nonredundant with peroxidase for lignin polymerization during vascular development in Arabidopsis. The Plant Cell, v. 25, n. 10, p. 3976-3987, 2013. 